\title{
Statistical Assessment of Soccer Players
}

\author{
by \\ Mohammad-Amin Nabavi
}

A thesis submitted to the Faculty of Graduate and Postdoctoral Affairs in partial fulfillment of the requirements

for the degree

Master of Science

in

Mathematics and Statistics

Carleton University

Ottawa, Ontario

(C) 2019

Mohammad-Amin Nabavi 


\begin{abstract}
This thesis examines the use of neural network modelling and ordinal logistic regression on a single season of data (2015-16) to score or rank soccer players. These scores and ranks are then compared with ones from FIFA EASports that are based on a much more extensive data set that includes more variables as well as historical data. Using repeated measures one-way ANOVA and subsequent multiple comparison testing, we conclude that a neural network model with ten nodes in one hidden layer is able to generate scores statistically similar to FIFA EASports, while ordinal logistic regression cannot. We confirm this result be also examining the ranks obtained by both the neural network model and the ordinal logistic regression model. Spearman rank correlations are also examined and confirm that a neural network with 10 nodes in one hidden layer also generates ranks statistically similar to FIFA EASports. We also demonstrate the use of association rule mining on one team's data from the $2015-16$ season to identify players and combinations thereof that are associated with winning (or not winning) a match. Analyses are based on data from the Italian Serie A League 2015-2016 season.
\end{abstract}




\section{Acknowledgements}

These past couple of years have proven to be the hardest period of my life so far. I could not be here without the help of the people around me. I have been surrounded by the kindest people. I want to thank my parents for their support without any hesitation. I want to thank my brother and sister who have always been there for me. I want to thank Gray Barski and Shintara Hagiwara for many discussions about this research and for their moral encouragement.

Last but not the least, I want to thank my supervisor, Dr. Mills. She supported me during this hard time and never gave up on me. I am blessed with being her student. 


\section{Table of Contents}

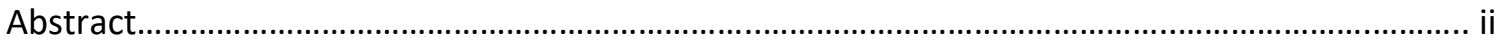

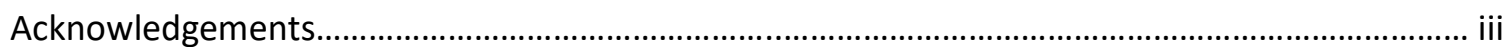

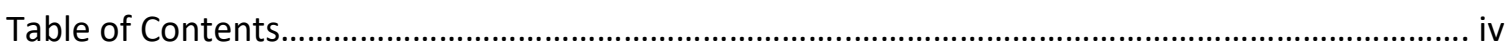

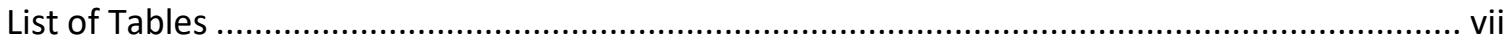

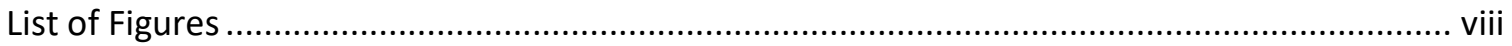

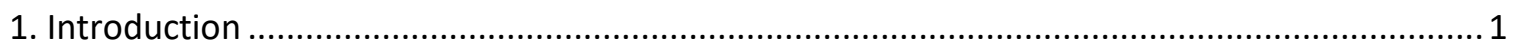

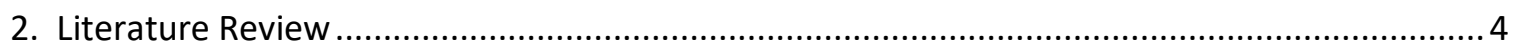

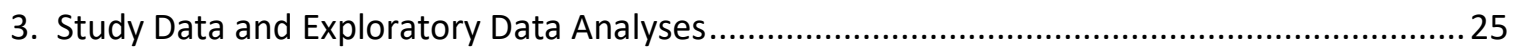

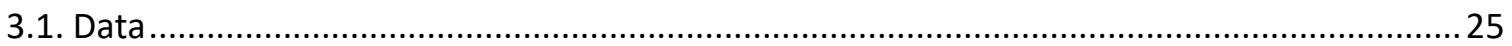

3.1.1. Definition of the Variables ..................................................................... 25

3.1.2. Structure of the Data Sets ....................................................................... 26

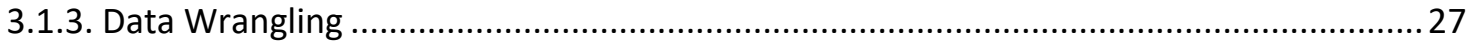

3.2. Exploratory Data Analyses ......................................................................... 28

3.2.1. Descriptive Statistics .............................................................................. 28

3.2.1.1. Defenders........................................................................................ 29

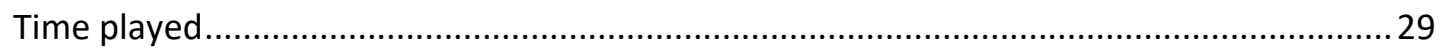

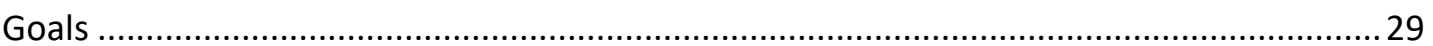

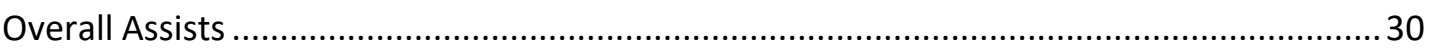


Warning Cards.

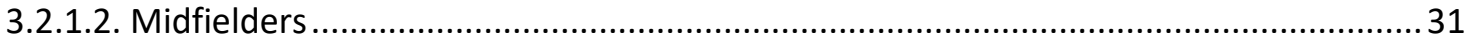

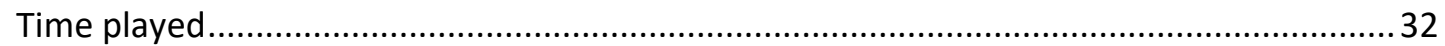

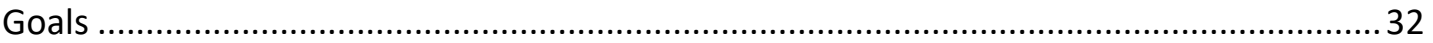

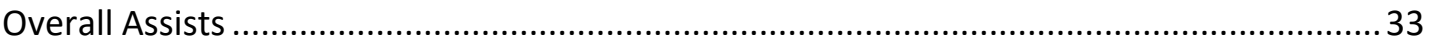

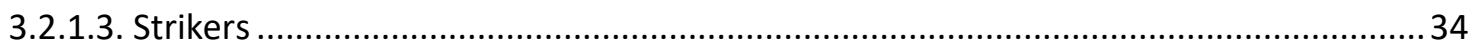

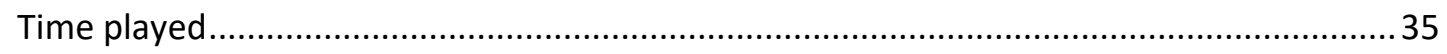

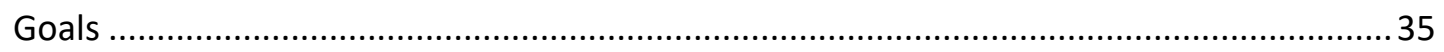

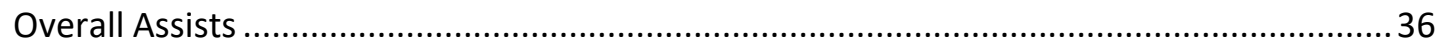

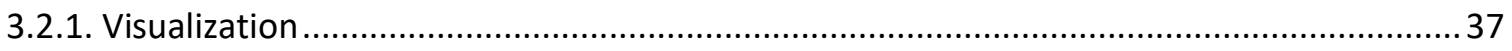

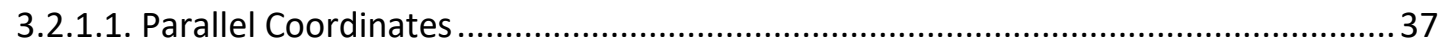

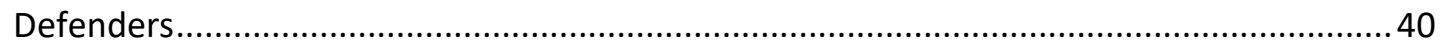

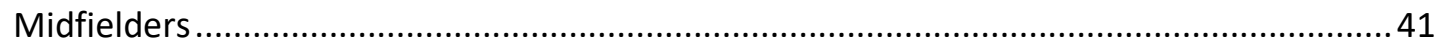

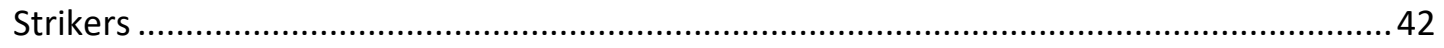

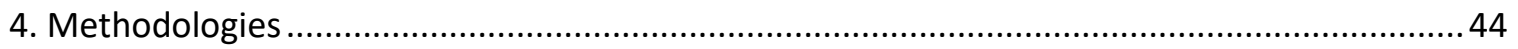

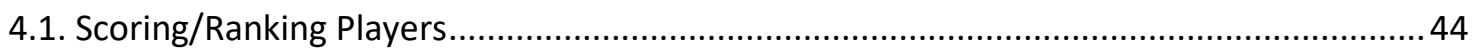

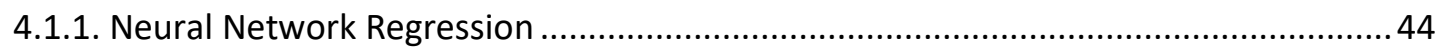

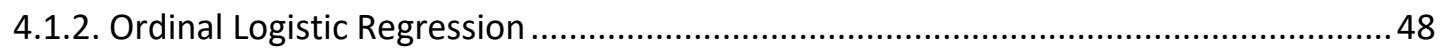

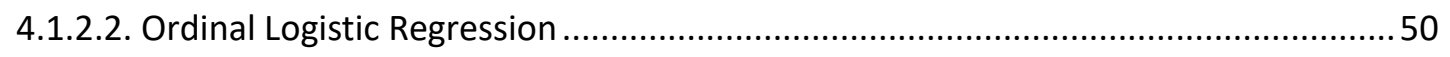

4.1.2.3 Comparison of scoring and ranking methods .................................................... 51 


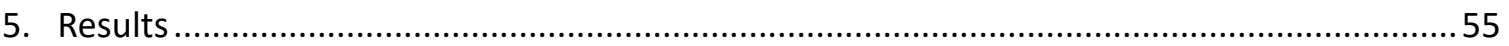

5.1. Scoring/Ranking Players Based on Performance during the 2015-16 Season..................55

5.1.1. Preparation of the Data for Scoring and Ranking ...........................................56

5.1.2. Scoring Players: Using Neural Networks ................................................... 59

5.1.3. Scoring/Ranking Model: Using Ordinal Regression .......................................... 79

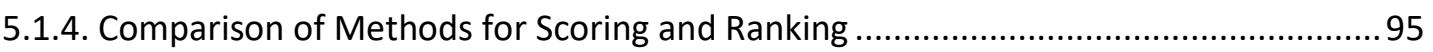

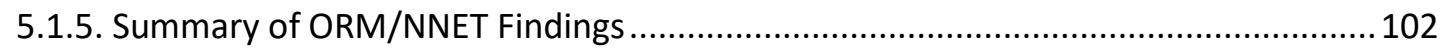

5.2. Association rule mining ........................................................................... 103

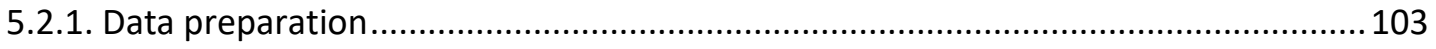

5.2.2. Results: Association rule mining .......................................................... 105

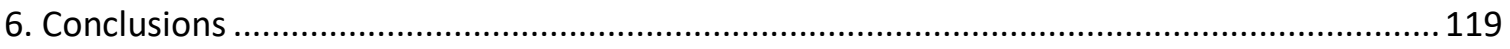

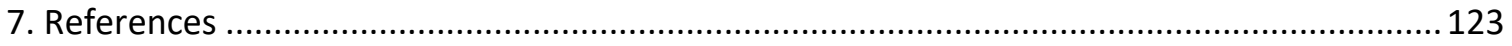




\section{List of Tables}

Table 1:Empirical studies with predominantly descriptive analysis.

Table 2:Comparative studies with predominantly comparative analysis according to the different functional positions of the players. 7

Table 3:Empirical studies with predominantly comparative analysis based on the different competitive levels.

Table 4:Empirical studies with situational - match status, quality of opposition and match location. 14

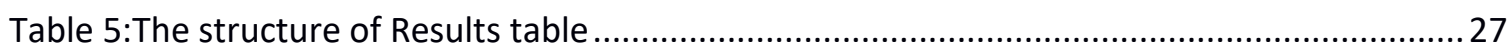

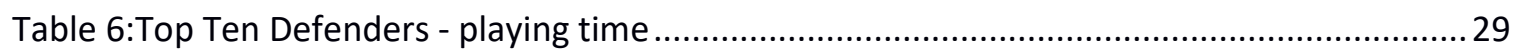

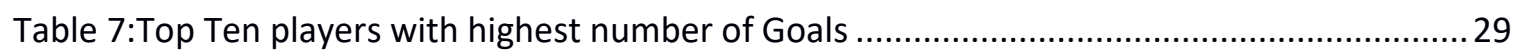

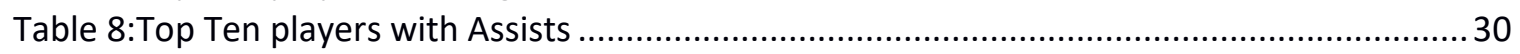

Table 9:Top Ten Defenders with highest number of warning cards ......................................... 31

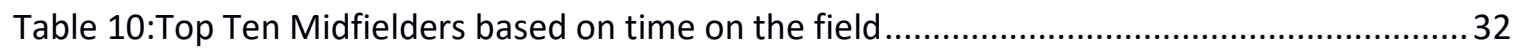

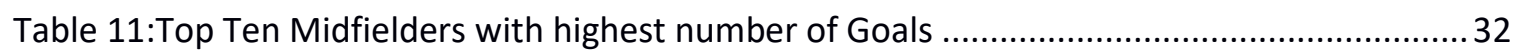

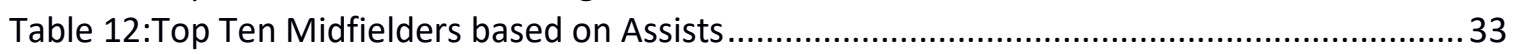

Table 13:Top Ten Midfielders with highest number of warning cards ....................................... 34

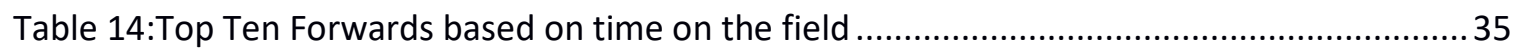

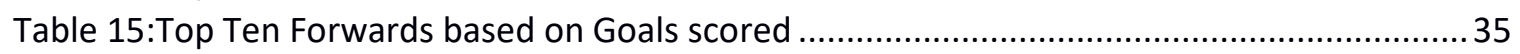

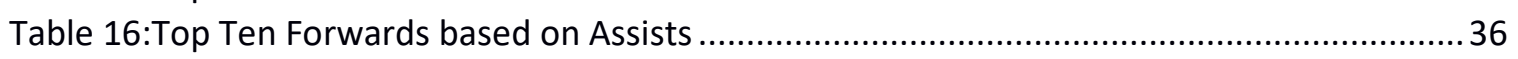

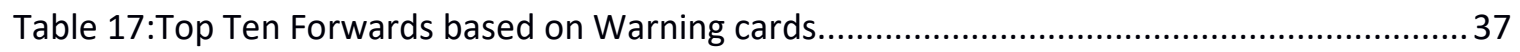

Table 18:The summary of NNET Model1 with two hidden nodes and no initial assigned weights

Table 19:The summary of NNET Model2 with two hidden nodes with starting weights from the NNET Model1

Table 20:The summary of NNET Model3 with ten nodes in hidden layer and no initial starting weights

Table 21:The summary of NNET Model 4 with 10 nodes in the hidden layer and starting weights

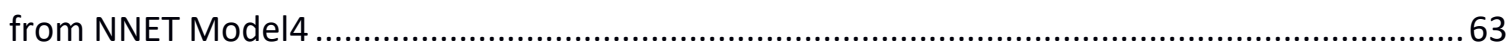

Table 22:Players with EASports score and prediction from NNET Model4 .................................64

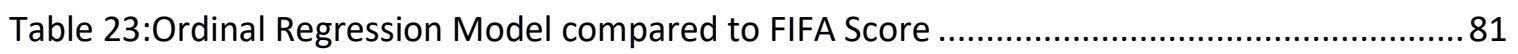

Table 24:repeated measures One-Way ANOVA Model................................................................96

Table 25:Tukey multiple comparisons of means $99 \%$ family-wise confidence level.....................98

Table 26:Mauchly test for sphericity ....................................................................................98

Table 27:Pairwise comparisons using Wilcoxon rank sum test * $p$-value adjustment method: BH



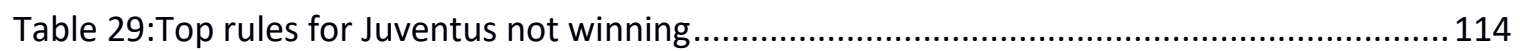




\section{List of Figures}

Figure 1: Opta Index Scores for Thierry Henry over season 2003-04 when playing for Arsenal

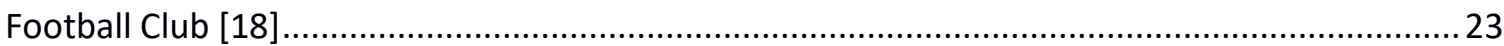

Figure 2: The evolution of Thierry Henry's financial value over season 2003-04 [18] .................23

Figure 3: The evolution of injuries for Manchester United in season 2003-04 ...........................24

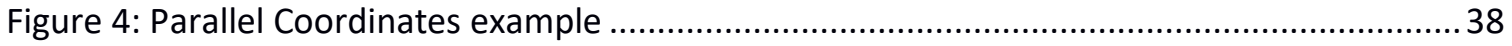

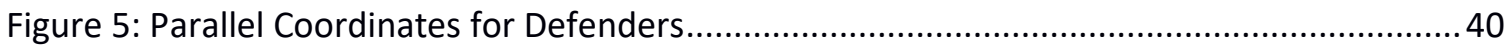

Figure 6: Parallel Coordinates for Midfielders ..................................................................... 41

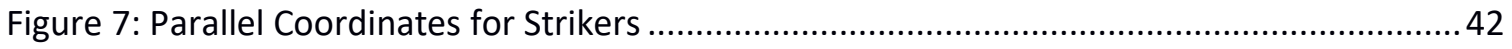

Figure 8: Chart of Correlation Matrix for predictor variables...................................................58

Figure 9: Residual Plot using 2 hidden Nodes with for NNet Model1 and random initial weights60

Figure 10: Residual Plot for NNET Model2 using 2 hidden nodes with initial weights from NNet

Model1

Figure 11: Residual Pot for NNET Model3 with ten nodes in hidden layer and no initial starting weights... . .62

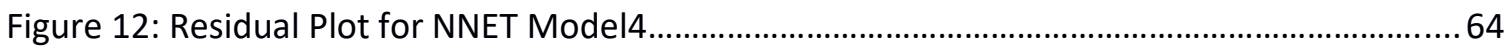

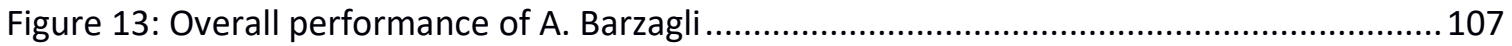

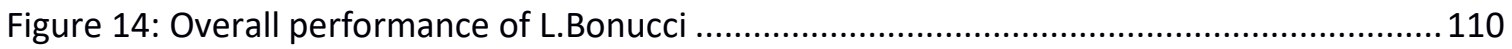

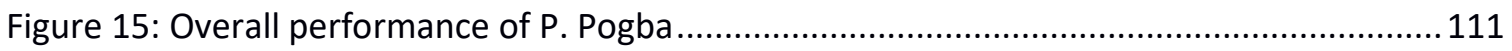

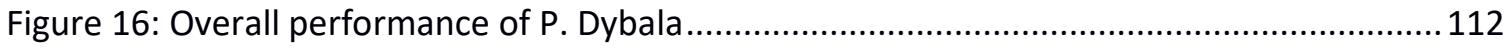

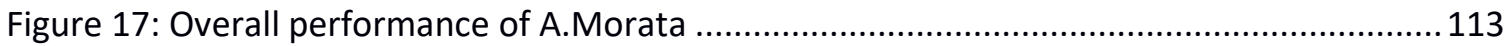

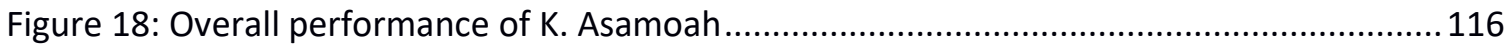

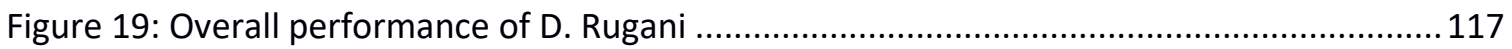

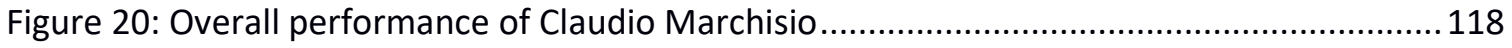

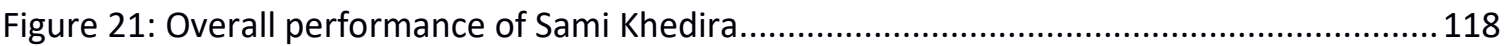




\section{Introduction}

Soccer is the world's largest grossing sport with annual revenues within some leagues surpassing the GDP of some small countries. In the last 30 years the development and implementation of data analytics in soccer has become increasingly popular. Predictive models from quantitative measurements have been shown to provide useful inferences that have not been available traditionally from experts within the sport. With the worldwide popularity of soccer, there exists significant incentive to perform such analyses since the rewards are potentially quite large. However, due to the dynamic nature of the sport, data analysis on a sport like soccer is quite challenging.

The results of this work can be used for different purposes. These analyses can be used by coaches, managers, players and agents. Also, these types of statistical analysis can be used by video game companies, betting organizations, and fans. It must be mentioned that this work can be used for other sports as well. Soccer is dynamic; players' decisions are evolving sequentially and contingent upon other players' choices amongst other phenomena. Although an immense amount of data is tracked and published, many of these sources are not free or readily available to the public. One firm that provides datasets is Opta [1]. Opta is one of the largest companies that provide data for other parties. They also have their own analytical team and prepare analytical inferences for different parties such as betting 
companies. Obtaining an accessible and suitable dataset is quite difficult; the task requires an immense amount of resources to gather and compile such a data set. The data that is readily available to the public is generally expressed in raw form and requires substantial manipulations, organization, and computational techniques in order to be brought into a form which allows for statistical inference. Statistical predictive modelling will be highly dependent upon obtaining a suitable data set. The statistical problem in mind must not only be well defined by the researcher but also, the methods and procedures used to attempt to solve the problem must be tailored in a manner that addresses the previous constraints.

This thesis explicitly considers the following questions:

1.) Can we use statistical learning methods to duplicate the FIFA rankings from EA Sports' 2016 players' rankings? (We did not have access to the formulae, or the complete data set implemented within that system).

2.) Can we find a methodology that provides insight into players or combinations of players that increase the chance of a team winning a match? Similarly, can we find a methodology that identifies players or combinations of players that decrease the chance of a team winning a match? One way of describing this objective in simpler qualitative terms is attempting to find a methodology that would identify a player or a set 
of players whose presence (or absence) makes a difference on winning a game.

We are interested in investigating whether statistical machine learning can address these questions. To conduct our research we will use data from Italian Serie A League for the 2015-2016 season [2]. Chapter 2 of this thesis provides a literature review summarizing relevant contributions to soccer analytics that exist within the academic literature. Chapter 3 discusses the dataset used and associated data wrangling. Chapter 4 presents methodological procedures proposed to address the research questions. The first section has the primary goal of examining methods for finding and assessing the accuracy of scoring/ranking models based on event data. Two different models proposed in this section are Neural Networks(NNET) and Ordinal Logistic Regression(ORM). We compare our results to those from the scores of EA Sports' FIFA 2015-16. The second section is concerned with methodology for finding a player or set of players that are associated with winning (or not winning) a match. For this objective, association rule mining is proposed. Chapter 4 concludes the explanation of the methodologies with a discussion of the relative utility of each methodology. Chapter 5 presents the results of each methodological procedure implemented within this thesis. Finally, Chapter 6 provides conclusions, a discussion about possible alternative methodologies, and motivates future research. 


\section{Literature Review}

This chapter presents a review of the literature relevant to the research questions posed in this thesis. Sarmento et al [3] published a paper that systematically reviewed and organised the literature on match analysis in 
adult male football in an attempt to identify the most common research topics, to characterise their methodologies, and to systematise the evolutionary tendencies on this topic. It contained a review of 53 papers and categorized them into four (4) categories:

1. Empirical studies with predominantly descriptive analysis.

2. Comparative studies with predominantly comparative analysis according to the different functional positions of the players.

3. Empirical studies with predominantly comparative analysis based on the different competitive levels.

4. Empirical studies with situational - match status, quality of opposition and match location.

Table 1:Empirical studies with predominantly descriptive analysis.

\begin{tabular}{|l|l|l|l|}
\hline Study & Sample & Movement Category & Procedure \\
\hline $\begin{array}{l}\text { Barros et al. } \\
(2007)\end{array}$ & $\begin{array}{l}\text { 55 players of First } \\
\text { Brazilian Division }\end{array}$ & $\begin{array}{l}\text { Standing/walking/jogging, } \\
\text { low-speed running, } \\
\text { moderate-speed running, } \\
\text { high-speed running, } \\
\text { sprinting. }\end{array}$ & $\begin{array}{l}\text { Video analysis of } \\
\text { the activity of } \\
\text { players. }\end{array}$ \\
\hline $\begin{array}{l}\text { Di Salvo et al. } \\
(2007)\end{array}$ & $\begin{array}{l}300 \text { players of } \\
\text { Spanish Premier } \\
\text { League }\end{array}$ & $\begin{array}{l}\text { Standing/walking/jogging, } \\
\text { low-speed running, } \\
\text { moderate-speed running, } \\
\text { high-speed running, } \\
\text { sprinting. }\end{array}$ & $\begin{array}{l}\text { Computerised } \\
\text { match analysis } \\
\text { system (AMISCO) }\end{array}$ \\
\hline
\end{tabular}




\begin{tabular}{|c|c|c|c|}
\hline $\begin{array}{l}\text { Rampinini, } \\
\text { Coutts, } \\
\text { Castagna, } \\
\text { Sassi, and } \\
\text { Impellizzeri } \\
\text { (2007) } \\
\end{array}$ & $\begin{array}{l}20 \text { players of a } \\
\text { successful team } \\
\text { that participated in } \\
\text { a major European } \\
\text { National League }\end{array}$ & $\begin{array}{l}\text { Standing, walking, } \\
\text { jogging, running, high- } \\
\text { speed running, sprinting. }\end{array}$ & $\begin{array}{l}\text { Computerised } \\
\text { match analysis } \\
\text { system } \\
\text { (ProZone) }\end{array}$ \\
\hline $\begin{array}{l}\text { Di Salvo, } \\
\text { Benito, } \\
\text { Calderon, Di } \\
\text { Salvo, and } \\
\text { Pigozzi (2008) }\end{array}$ & $\begin{array}{l}62 \text { goalkeepers of } \\
\text { English Premier } \\
\text { League }\end{array}$ & $\begin{array}{l}\text { Walking, jogging, running, } \\
\text { high-speed run, sprinting } \\
\text { and total distance. }\end{array}$ & $\begin{array}{l}\text { Computerised } \\
\text { match analysis } \\
\text { system } \\
\text { (ProZone) }\end{array}$ \\
\hline $\begin{array}{l}\text { Bradley, Di } \\
\text { Mascio,Peart, } \\
\text { Olsen, and } \\
\text { Sheldon (2010) }\end{array}$ & $\begin{array}{l}110 \text { players of } \\
\text { European } \\
\text { successful teams }\end{array}$ & $\begin{array}{l}\text { Standing, walking, } \\
\text { jogging, running, high- } \\
\text { speed running, sprinting. }\end{array}$ & $\begin{array}{l}\text { Computerised } \\
\text { match analysis } \\
\text { system } \\
\text { (ProZone) }\end{array}$ \\
\hline $\begin{array}{l}\text { Gregson, Drust, } \\
\text { Atkinson, and } \\
\text { Di Salvo (2010) }\end{array}$ & $\begin{array}{l}485 \text { players of the } \\
\text { English Premier } \\
\text { League }\end{array}$ & $\begin{array}{l}\text { Total high-speed running } \\
\text { (expressed as both high } \\
\text { speed running distance } \\
\text { completed with the } \\
\text { respective players team } \\
\text { in possession and without } \\
\text { possession), high-speed } \\
\text { running distance, total } \\
\text { sprint distance. }\end{array}$ & $\begin{array}{l}\text { Computerised } \\
\text { match analysis } \\
\text { system } \\
\text { (ProZone) }\end{array}$ \\
\hline $\begin{array}{l}\text { Vigne, } \\
\text { Gaudino, } \\
\text { Rogowski, } \\
\text { Alloatti, and } \\
\text { Hautier (2010) }\end{array}$ & $\begin{array}{l}388 \text { players of the } \\
\text { Italian Series A }\end{array}$ & $\begin{array}{l}\text { Walking, jogging, speed } \\
\text { below the anaerobic } \\
\text { threshold, speed above } \\
\text { the anaerobic threshold, } \\
\text { sprint. }\end{array}$ & $\begin{array}{l}\text { Computerised } \\
\text { match analysis } \\
\text { system (SICS) }\end{array}$ \\
\hline Carling (2011) & $\begin{array}{l}21 \text { players of } \\
\text { French League } 1 \\
\text { division }\end{array}$ & $\begin{array}{l}\text { Total distance covered in: } \\
\text { low-to-moderate } \\
\text { intensity; high intensity; } \\
\text { very high intensity. }\end{array}$ & $\begin{array}{l}\text { Computerised } \\
\text { match analysis } \\
\text { system (AMISCO) }\end{array}$ \\
\hline $\begin{array}{l}\text { Castellano, } \\
\text { Blanco- } \\
\text { Villaseñor, and } \\
\text { Álvarez (2011) }\end{array}$ & $\begin{array}{l}34 \text { players of } \\
\text { Spanish Premier } \\
\text { League }\end{array}$ & $\begin{array}{l}\text { Standing/walking/jogging, } \\
\text { low-speed running, } \\
\text { moderate-speed running, } \\
\text { high-speed running, very } \\
\text { high-speed running, } \\
\text { sprinting. }\end{array}$ & $\begin{array}{l}\text { Computerised } \\
\text { match analysis } \\
\text { system (AMISCO) }\end{array}$ \\
\hline $\begin{array}{l}\text { Robinson, } \\
\text { O'Donoghue, } \\
\text { and Wooster } \\
\text { (2011) }\end{array}$ & $\begin{array}{l}180 \text { players of the } \\
\text { English Premier } \\
\text { League }\end{array}$ & $\begin{array}{l}\text { Path changes of: } 45^{\circ} \text { to } \\
135 \text { o to the left; } 45^{\circ} \text { to } \\
135 \text { o to the right; more } \\
\text { than } 135^{\circ} \text { to the left or } \\
\text { the right. }\end{array}$ & $\begin{array}{l}\text { Computerised } \\
\text { match analysis } \\
\text { system } \\
\text { (ProZone) }\end{array}$ \\
\hline
\end{tabular}


Table 2:Comparative studies with predominantly comparative analysis according to the different functional positions of the players.

\begin{tabular}{|c|c|c|c|c|}
\hline Study & Sample & $\begin{array}{l}\text { Categories of } \\
\text { player } \\
\text { positions }\end{array}$ & $\begin{array}{l}\text { Analysed } \\
\text { variables }\end{array}$ & Main results \\
\hline $\begin{array}{l}\text { Barros et al. } \\
\text { (2007) }\end{array}$ & $\begin{array}{l}55 \text { players of } \\
\text { First } \\
\text { Brazilian } \\
\text { Division. }\end{array}$ & $\begin{array}{l}\text { Central } \\
\text { defenders, } \\
\text { external } \\
\text { defenders, } \\
\text { central } \\
\text { midfielder, } \\
\text { external } \\
\text { midfielder, } \\
\text { forwards. }\end{array}$ & $\begin{array}{l}\text { Distances } \\
\text { covered at } \\
\text { different } \\
\text { intensities. }\end{array}$ & $\begin{array}{l}\text { The distances } \\
\text { covered by } \\
\text { external } \\
\text { defenders, } \\
\text { central } \\
\text { midfielders } \\
\text { and } \\
\text { external } \\
\text { midfielders } \\
\text { were greater } \\
\text { than } \\
\text { forwards. The } \\
\text { forwards } \\
\text { covered } \\
\text { greater } \\
\text { distances } \\
\text { than central } \\
\text { defenders. }\end{array}$ \\
\hline $\begin{array}{l}\text { Bloomfield } \\
\text { et al. } \\
\text { (2007) }\end{array}$ & $\begin{array}{l}55 \text { of the English } \\
\text { Premier League. }\end{array}$ & $\begin{array}{l}\text { Defenders, } \\
\text { midfielders } \\
\text { and forwards. }\end{array}$ & $\begin{array}{l}\text { Purposeful } \\
\text { movements } \\
\text { (PM). }\end{array}$ & $\begin{array}{l}\text { The specific } \\
\text { position on } \\
\text { the field had a } \\
\text { significant } \\
\text { influence on } \\
\text { \%PM time } \\
\text { spent } \\
\text { sprinting, } \\
\text { running, } \\
\text { shuffling, } \\
\text { skipping and } \\
\text { standing still. } \\
\text { The } \\
\text { position had } \\
\text { no significant } \\
\text { influence } \\
\text { on the \%PM } \\
\text { time spent } \\
\text { performing }\end{array}$ \\
\hline
\end{tabular}




\begin{tabular}{|c|c|c|c|c|}
\hline & & & & $\begin{array}{l}\text { movement at } \\
\text { low, medium, } \\
\text { high or } \\
\text { very high } \\
\text { intensities. }\end{array}$ \\
\hline $\begin{array}{l}\text { Di Salvo et } \\
\text { al. } \\
(2007)\end{array}$ & $\begin{array}{l}300 \text { of Spanish } \\
\text { Premier League. }\end{array}$ & $\begin{array}{l}\text { Central } \\
\text { defenders, } \\
\text { external } \\
\text { defenders, } \\
\text { central } \\
\text { midfielder, } \\
\text { external } \\
\text { midfielder, } \\
\text { forwards. }\end{array}$ & $\begin{array}{l}\text { Distances } \\
\text { covered at } \\
\text { different } \\
\text { intensities. }\end{array}$ & $\begin{array}{l}\text { Midfield } \\
\text { players } \\
\text { covered a } \\
\text { significantly } \\
\text { greater total } \\
\text { distance than } \\
\text { the groups } \\
\text { of defenders } \\
\text { and forwards. } \\
\text { The } \\
\text { shortest } \\
\text { distance was } \\
\text { covered by } \\
\text { central } \\
\text { defenders. } \\
\end{array}$ \\
\hline $\begin{array}{l}\text { Rampinini } \\
\text { et al. } \\
\text { (2007) }\end{array}$ & $\begin{array}{l}20 \text { players of a } \\
\text { successful team } \\
\text { that } \\
\text { participated in a } \\
\text { major European } \\
\text { National League. }\end{array}$ & $\begin{array}{l}\text { Centre-back, } \\
\text { fullback, } \\
\text { midfielder, } \\
\text { forward. }\end{array}$ & $\begin{array}{l}\text { Match } \\
\text { activities, } \\
\text { match } \\
\text { distances, } \\
\text { other match } \\
\text { analysis } \\
\text { measures. }\end{array}$ & $\begin{array}{l}\text { Difference of } \\
\text { all variables } \\
\text { between } \\
\text { player } \\
\text { positions }\end{array}$ \\
\hline $\begin{array}{l}\text { Di Salvo et } \\
\text { al. } \\
(2009)\end{array}$ & $\begin{array}{l}563 \text { of the } \\
\text { English } \\
\text { Premier League. }\end{array}$ & $\begin{array}{l}\text { Central } \\
\text { defenders, } \\
\text { external } \\
\text { defenders, } \\
\text { central } \\
\text { midfielder, } \\
\text { external } \\
\text { midfielder, } \\
\text { forwards. }\end{array}$ & $\begin{array}{l}\text { High-intensity } \\
\text { running } \\
\text { activity. }\end{array}$ & $\begin{array}{l}\text { The total } \\
\text { high-intensity } \\
\text { running was } \\
\text { dependent } \\
\text { upon playing } \\
\text { position } \\
\text { with the } \\
\text { external } \\
\text { midfielders } \\
\text { completing } \\
\text { the highest } \\
\text { and lowest } \\
\text { distance, } \\
\text { respectively. }\end{array}$ \\
\hline $\begin{array}{l}\text { Dellal et al. } \\
\text { (2010) }\end{array}$ & $\begin{array}{l}3540 \text { players of } \\
\text { French League } 1 \\
\text { division. }\end{array}$ & $\begin{array}{l}\text { Central } \\
\text { defenders, } \\
\text { fullbacks, } \\
\text { central } \\
\text { defensive } \\
\text { midfielders, }\end{array}$ & $\begin{array}{l}\text { Physical } \\
\text { parameters } \\
\text { (distances } \\
\text { covered in } \\
\text { high intensity } \\
\text { and }\end{array}$ & $\begin{array}{l}\text { In the } \\
\text { offensive } \\
\text { phase, the } \\
\text { forwards } \\
\text { covered } \\
\text { about } 4 \text { times }\end{array}$ \\
\hline
\end{tabular}




\begin{tabular}{|c|c|c|c|c|}
\hline & & $\begin{array}{l}\text { wide } \\
\text { midfielders, } \\
\text { central } \\
\text { attacking } \\
\text { midfielders, } \\
\text { forwards. }\end{array}$ & $\begin{array}{l}\text { sprinting, of } \\
\text { ground } \\
\text { duels or } \\
\text { heading duels } \\
\text { won. Technical } \\
\text { parameters } \\
\text { (successful } \\
\text { passes, total } \\
\text { duration of } \\
\text { individual ball } \\
\text { possession, } \\
\text { number of } \\
\text { touches per } \\
\text { individual } \\
\text { possession). }\end{array}$ & $\begin{array}{l}\text { more the } \\
\text { total } \\
\text { distances in } \\
\text { sprinting than } \\
\text { central } \\
\text { defenders } \\
\text { and full backs. } \\
\text { Midfielders } \\
\text { performed } \\
\text { successful } \\
\text { passes } \\
\text { ranging from } \\
75 \% \text { to } 78 \%, \\
\text { whereas } \\
\text { lower values } \\
\text { were found } \\
\text { for the } \\
\text { forwards } \\
\text { (71\%) and } \\
\text { central } \\
\text { defenders } \\
\text { (63\%), } \\
\text { respectively }\end{array}$ \\
\hline $\begin{array}{l}\text { Di Salvo et } \\
\text { al. } \\
(2010)\end{array}$ & $\begin{array}{l}717 \text { players of } \\
\text { Champions } \\
\text { League } \\
\text { teams. }\end{array}$ & $\begin{array}{l}\text { Central } \\
\text { defenders, } \\
\text { external } \\
\text { defenders, } \\
\text { central } \\
\text { midfielder, } \\
\text { external } \\
\text { midfielder, } \\
\text { forwards. }\end{array}$ & $\begin{array}{l}\text { Total number } \\
\text { of sprints } \\
\text { and total } \\
\text { sprint distance } \\
\text { covered. }\end{array}$ & $\begin{array}{l}\text { Differences } \\
\text { were found in } \\
\text { most of the } \\
\text { analysed } \\
\text { variables } \\
\text { depending on } \\
\text { the } \\
\text { specific } \\
\text { position on } \\
\text { the field. } \\
\text { Wide } \\
\text { midfielders } \\
\text { performed a } \\
\text { higher } \\
\text { number of } \\
\text { sprints in all } \\
\text { five distance } \\
\text { categories } \\
\text { than all other } \\
\text { positions. }\end{array}$ \\
\hline $\begin{array}{l}\text { Vigne et al. } \\
\text { (2010) }\end{array}$ & $\begin{array}{l}388 \text { players of } \\
\text { the } \\
\text { Italian Series A. }\end{array}$ & $\begin{array}{l}\text { Defenders, } \\
\text { midfielders } \\
\text { and forwards. }\end{array}$ & $\begin{array}{l}\text { Distances } \\
\text { covered at } \\
\text { different } \\
\text { intensities. }\end{array}$ & $\begin{array}{l}\text { The } \\
\text { midfielders } \\
\text { covered } \\
\text { significantly }\end{array}$ \\
\hline
\end{tabular}




\begin{tabular}{|c|c|c|c|c|}
\hline & & & & $\begin{array}{l}\text { more distance } \\
\text { than players } \\
\text { in other } \\
\text { positions. For } \\
\text { midfielders, } \\
\text { the } \\
\text { number of } \\
\text { displacements } \\
\text { of } 2-40 \mathrm{~m} \\
\text { and the } \\
\text { number of } \\
\text { sprints } \\
\text { covering } \\
\text { between } 2 \\
\text { and } 9 \mathrm{~m} \text { and } \\
\text { between } 30 \\
\text { and } 40 \mathrm{~m} \text { are } \\
\text { considerably } \\
\text { greater } \\
\text { than for other } \\
\text { positions. }\end{array}$ \\
\hline $\begin{array}{l}\text { Dellal et al. } \\
\text { (2011) }\end{array}$ & $\begin{array}{l}5938 \text { of the } \\
\text { English } \\
\text { Premier League } \\
\text { and of Spanish } \\
\text { Premier League. }\end{array}$ & $\begin{array}{l}\text { Central } \\
\text { defenders, } \\
\text { fullbacks, } \\
\text { central } \\
\text { defensive } \\
\text { midfielders, } \\
\text { wide } \\
\text { midfielders, } \\
\text { central } \\
\text { attacking } \\
\text { midfielders, } \\
\text { forwards. }\end{array}$ & $\begin{array}{l}\text { Distances } \\
\text { covered at } \\
\text { different } \\
\text { intensities. } \\
\text { Technical } \\
\text { parameters. }\end{array}$ & $\begin{array}{l}\text { English } \\
\text { Premier } \\
\text { League and } \\
\text { Spanish } \\
\text { Premier } \\
\text { League teams } \\
\text { present } \\
\text { differences in } \\
\text { various } \\
\text { physical and } \\
\text { technical } \\
\text { aspects of } \\
\text { match play, } \\
\text { suggesting } \\
\text { that cultural } \\
\text { differences } \\
\text { may exist } \\
\text { across } \\
\text { professional } \\
\text { soccer } \\
\text { leagues and } \\
\text { playing } \\
\text { positions. }\end{array}$ \\
\hline
\end{tabular}


Table 3:Empirical studies with predominantly comparative analysis based on the different competitive levels.

\begin{tabular}{|c|c|c|c|c|}
\hline Study & Sample & $\begin{array}{l}\text { Number of } \\
\text { considered } \\
\text { levels }\end{array}$ & $\begin{array}{l}\text { Strategies used } \\
\text { to established } \\
\text { the levels }\end{array}$ & Results \\
\hline $\begin{array}{l}\text { O'Donoghue } \\
\text { et al. (2001) }\end{array}$ & $\begin{array}{l}72 \text { players of } \\
\text { the } \\
\text { English } \\
\text { Championships }\end{array}$ & Three & $\begin{array}{l}\text { Elite, amateurs } \\
\text { and semi- } \\
\text { professional } \\
\text { players }\end{array}$ & $\begin{array}{l}\text { Semi- } \\
\text { professional } \\
\text { players } \\
\text { performed } \\
\text { more } \\
\text { discrete } \\
\text { movements } \\
\text { than the } \\
\text { other } \\
\text { players. } \\
\text { Amateur } \\
\text { players } \\
\text { performed a } \\
\text { significantly } \\
\text { lower } \\
\text { number of } \\
\text { periods of } \\
\text { high- } \\
\text { intensity } \\
\text { activity than } \\
\text { elite and } \\
\text { amateur } \\
\text { players. } \\
\text { However, the } \\
\text { duration } \\
\text { of the } \\
\text { periods of } \\
\text { high- } \\
\text { intensity } \\
\text { activity } \\
\text { performed } \\
\text { by amateur } \\
\text { players was } \\
\text { significantly } \\
\text { longer than } \\
\text { those } \\
\text { performed }\end{array}$ \\
\hline
\end{tabular}




\begin{tabular}{|c|c|c|c|c|}
\hline & & & & $\begin{array}{l}\text { by the other } \\
\text { groups of } \\
\text { players. }\end{array}$ \\
\hline $\begin{array}{l}\text { Hughes and } \\
\text { Franks } \\
\text { (2005) }\end{array}$ & $\begin{array}{l}116 \text { matches of } \\
\text { the } \\
1990 \text { (Italy) and } \\
1994 \text { (USA) } \\
\text { World Cup }\end{array}$ & Two & $\begin{array}{l}\text { Successful teams } \\
\text { (quarterfinalists) } \\
\text { and unsuccessful } \\
\text { teams (first } \\
\text { round losers) }\end{array}$ & $\begin{array}{l}\text { For } \\
\text { successful } \\
\text { teams, } \\
\text { longer } \\
\text { passing } \\
\text { sequences } \\
\text { produced } \\
\text { more goals } \\
\text { per } \\
\text { possession } \\
\text { than shorter } \\
\text { passing } \\
\text { sequences. } \\
\text { For } \\
\text { unsuccessful } \\
\text { teams, } \\
\text { neither tactic } \\
\text { had a clear } \\
\text { advantage. }\end{array}$ \\
\hline $\begin{array}{l}\text { Rampinini } \\
\text { et al. } \\
\text { (2009) }\end{array}$ & $\begin{array}{l}186 \text { players of } \\
\text { the } \\
\text { Italian Series A }\end{array}$ & Two & $\begin{array}{l}\text { Successful teams } \\
\text { (ranked in the } \\
\text { first five } \\
\text { positions) vs. less } \\
\text { successful teams } \\
\text { (ranked in the } \\
\text { last five } \\
\text { positions) }\end{array}$ & $\begin{array}{l}\text { The players } \\
\text { from the } \\
\text { more } \\
\text { successful } \\
\text { teams } \\
\text { covered } \\
\text { greater total } \\
\text { distance with } \\
\text { the ball and } \\
\text { very high- } \\
\text { intensity } \\
\text { running } \\
\text { distance and } \\
\text { also had } \\
\text { more } \\
\text { involvements } \\
\text { with the ball, } \\
\text { completed } \\
\text { more short } \\
\text { passes, } \\
\text { successful } \\
\text { short } \\
\text { passes, } \\
\text { tackles, } \\
\text { dribbling, } \\
\text { shots, and }\end{array}$ \\
\hline
\end{tabular}




\begin{tabular}{|c|c|c|c|c|}
\hline & & & & $\begin{array}{l}\text { shots on } \\
\text { target } \\
\text { compared to } \\
\text { the less } \\
\text { successful } \\
\text { teams. }\end{array}$ \\
\hline $\begin{array}{l}\text { Bradley et } \\
\text { al. } \\
(2010)\end{array}$ & $\begin{array}{l}110 \text { players of } \\
\text { European } \\
\text { successful } \\
\text { teams }\end{array}$ & Two & $\begin{array}{l}\text { Elite domestic } \\
\text { players (that } \\
\text { played } \\
\text { in teams that } \\
\text { compete in one } \\
\text { of } \\
\text { the strongest } \\
\text { Leagues in the } \\
\text { world) vs. Elite } \\
\text { international } \\
\text { players (that } \\
\text { played in teams } \\
\text { ranked in the } \\
\text { Top } 10 \text { of the } \\
\text { FIFA }\end{array}$ & $\begin{array}{l}\text { No statistical } \\
\text { significant } \\
\text { differences } \\
\text { were } \\
\text { found } \\
\text { between the } \\
\text { groups for } \\
\text { high intensity } \\
\text { running } \\
\text { distance, } \\
\text { mean } \\
\text { recovery } \\
\text { time or } \\
\text { maximal } \\
\text { running } \\
\text { speed. }\end{array}$ \\
\hline $\begin{array}{l}\text { Lago- } \\
\text { Ballesteros } \\
\text { and Lago- } \\
\text { Peñas } \\
\quad(2010)\end{array}$ & $\begin{array}{l}380 \text { matches of } \\
\text { the } \\
\text { Spanish Premier } \\
\text { League }\end{array}$ & Three & $\begin{array}{l}\text { According to the } \\
\text { final ranking }\end{array}$ & $\begin{array}{l}\text { Top teams } \\
\text { had a higher } \\
\text { average of } \\
\text { goals for } \\
\text { total shots } \\
\text { and shots on } \\
\text { goal than } \\
\text { middle } \\
\text { and bottom } \\
\text { teams. } \\
\text { Bottom } \\
\text { teams } \\
\text { needed a } \\
\text { higher } \\
\text { number of } \\
\text { shots for } \\
\text { scoring a } \\
\text { goal than the } \\
\text { other groups } \\
\text { of } \\
\text { teams. } \\
\text { Middle } \\
\text { teams } \\
\text { showed a } \\
\text { lower }\end{array}$ \\
\hline
\end{tabular}




\begin{tabular}{|l|l|l|l|}
\hline & & value in \\
& & & assists and \\
ball \\
possession \\
than \\
top teams.
\end{tabular}

Table 4:Empirical studies with situational - match status, quality of opposition and match location.

\begin{tabular}{|c|c|c|c|c|}
\hline Study & Sample & Categories & Variable & Results \\
\hline $\begin{array}{l}\text { Lago and } \\
\text { Martín } \\
\text { (2007) }\end{array}$ & $\begin{array}{l}170 \text { games of } \\
\text { the } \\
\text { Spanish First } \\
\text { league }\end{array}$ & $\begin{array}{l}\text { Winning, } \\
\text { drawing, } \\
\text { losing } \\
\text { Home vs. away } \\
\text { Reference } \\
\text { team }\end{array}$ & $\begin{array}{l}\text { Percentage of } \\
\text { team } \\
\text { possession }\end{array}$ & $\begin{array}{l}\text { The teams } \\
\text { that played at } \\
\text { home had } \\
\text { more } \\
\text { possession } \\
\text { than the } \\
\text { teams playing } \\
\text { away. } \\
\text { When } \\
\text { loosing, } \\
\text { teams playing } \\
\text { at home had } \\
\text { more } \\
\text { possession } \\
\text { than when } \\
\text { they were } \\
\text { drawing or } \\
\text { winning. } \\
\text { The worse the } \\
\text { opposing } \\
\text { team, the } \\
\text { higher was } \\
\text { the } \\
\text { percentage of } \\
\text { ball } \\
\text { possession. }\end{array}$ \\
\hline $\begin{array}{l}\text { Taylor et al. } \\
(2008)\end{array}$ & $\begin{array}{l}40 \text { games of a } \\
\text { professional } \\
\text { English team }\end{array}$ & $\begin{array}{l}\text { Winning, } \\
\text { drawing, } \\
\text { losing }\end{array}$ & $\begin{array}{l}\text { Technical } \\
\text { Behaviours }\end{array}$ & $\begin{array}{l}\text { At winning: } \\
\text { teams } \\
\text { performed }\end{array}$ \\
\hline
\end{tabular}




\begin{tabular}{|c|c|c|c|c|}
\hline & & $\begin{array}{l}\text { Home vs. away } \\
\text { Home vs. away } \\
\text { Strong vs. weak }\end{array}$ & & $\begin{array}{l}\text { more } \\
\text { interception, } \\
\text { clearance and } \\
\text { aerial } \\
\text { challenge and } \\
\text { fewer } \\
\text { crosses, } \\
\text { passes and } \\
\text { dribbles. At } \\
\text { losing: teams } \\
\text { made more } \\
\text { crosses, } \\
\text { dribbles and } \\
\text { passes and } \\
\text { fewer } \\
\text { clearances } \\
\text { and } \\
\text { interceptions. } \\
\text { Playing at } \\
\text { home, } \\
\text { performed } \\
\text { more crosses } \\
\text { and shots, but } \\
\text { fewer } \\
\text { interceptions } \\
\text { and tackles. } \\
\text { When they } \\
\text { played } \\
\text { against strong } \\
\text { opponents, } \\
\text { they } \\
\text { performed } \\
\text { more passes } \\
\text { and less } \\
\text { dribbling. }\end{array}$ \\
\hline Lago (2009) & $\begin{array}{l}27 \text { games of the } \\
\text { Spanish first } \\
\text { League }\end{array}$ & $\begin{array}{l}\text { Winning, } \\
\text { drawing, } \\
\text { losing } \\
\text { Home vs. away } \\
\text { Strong vs. weak }\end{array}$ & $\begin{array}{l}\text { Percentage of } \\
\text { team } \\
\text { possession }\end{array}$ & $\begin{array}{l}\text { Possession } \\
\text { was greater } \\
\text { when losing } \\
\text { than when } \\
\text { winning or } \\
\text { drawing. } \\
\text { Playing } \\
\text { against strong } \\
\text { opponent } \\
\text { teams has } \\
\text { been } \\
\text { associated }\end{array}$ \\
\hline
\end{tabular}




\begin{tabular}{|c|c|c|c|c|}
\hline & & & & $\begin{array}{l}\text { with a } \\
\text { decrease in } \\
\text { time of } \\
\text { possession. } \\
\text { The } \\
\text { possession } \\
\text { was not } \\
\text { influenced by } \\
\text { the venue of } \\
\text { the game. }\end{array}$ \\
\hline $\begin{array}{l}\text { Lago et al. } \\
\text { (2010) }\end{array}$ & $\begin{array}{l}27 \text { players of } \\
\text { the } \\
\text { First Spanish } \\
\text { League }\end{array}$ & $\begin{array}{l}\text { Winning, } \\
\text { drawing, } \\
\text { losing } \\
\text { Home vs. away } \\
\text { Strong vs. weak }\end{array}$ & Work rate & $\begin{array}{l}\text { Playing } \\
\text { against strong } \\
\text { opponent } \\
\text { teams has } \\
\text { been } \\
\text { associated } \\
\text { with a } \\
\text { decrease in } \\
\text { time of } \\
\text { possession. } \\
\text { The } \\
\text { possession } \\
\text { was not } \\
\text { influenced by } \\
\text { the venue of } \\
\text { the game. } \\
\text { Players } \\
\text { covered } \\
\text { greater } \\
\text { distances } \\
\text { when they } \\
\text { played } \\
\text { against } \\
\text { strong } \\
\text { opposition. }\end{array}$ \\
\hline $\begin{array}{l}\text { Lago-Peñas } \\
\text { and } \\
\text { Dellal } \\
\text { (2010) }\end{array}$ & $\begin{array}{l}380 \text { games of } \\
\text { the } \\
\text { Spanish First } \\
\text { league }\end{array}$ & $\begin{array}{l}\text { Winning, } \\
\text { drawing, } \\
\text { losing } \\
\text { Home vs. away } \\
\text { Strong vs. weak }\end{array}$ & $\begin{array}{l}\text { Percentage of } \\
\text { team } \\
\text { possession }\end{array}$ & $\begin{array}{l}\text { The best } \\
\text { ranked teams } \\
\text { maintained a } \\
\text { high } \\
\text { percentage of } \\
\text { possession } \\
\text { and their } \\
\text { pattern of } \\
\text { play was } \\
\text { more stable. } \\
\text { Time }\end{array}$ \\
\hline
\end{tabular}




\begin{tabular}{|c|c|c|c|c|}
\hline & & & & $\begin{array}{l}\text { of possession } \\
\text { was greater } \\
\text { when teams } \\
\text { were losing } \\
\text { and when } \\
\text { they played at } \\
\text { home. Playing } \\
\text { against strong } \\
\text { opponents is } \\
\text { associated } \\
\text { with a } \\
\text { reduction in } \\
\text { time of } \\
\text { possession. }\end{array}$ \\
\hline $\begin{array}{l}\text { Lago-Peñas, } \\
\text { Lago- } \\
\text { Ballesteros, } \\
\text { et al. } \\
\text { (2011) }\end{array}$ & $\begin{array}{l}172 \text { players of } \\
\text { the } \\
\text { Spanish First } \\
\text { league }\end{array}$ & $\begin{array}{l}\text { Winning, } \\
\text { drawing, } \\
\text { losing } \\
\text { Home vs. away } \\
\text { Strong vs. weak }\end{array}$ & Work rate & $\begin{array}{l}\text { The elite } \\
\text { players } \\
\text { performed } \\
\text { less high } \\
\text { intensity } \\
\text { when winning } \\
\text { than when } \\
\text { losing. } \\
\text { The teams } \\
\text { playing at } \\
\text { home } \\
\text { covered } \\
\text { greater } \\
\text { distances at } \\
\text { low } \\
\text { intensity than } \\
\text { the teams } \\
\text { playing away. } \\
\text { Players } \\
\text { covered a } \\
\text { greater } \\
\text { distance } \\
\text { walking and } \\
\text { jogging when } \\
\text { playing } \\
\text { against } \\
\text { stronger } \\
\text { teams }\end{array}$ \\
\hline $\begin{array}{l}\text { Castellano } \\
\text { et al. } \\
(2011)\end{array}$ & $\begin{array}{l}434 \text { players of } \\
\text { the } \\
\text { Spanish First } \\
\text { league }\end{array}$ & $\begin{array}{l}\text { Winning, } \\
\text { drawing, } \\
\text { losing } \\
\text { Home vs. away }\end{array}$ & Work rate & $\begin{array}{l}\text { The total } \\
\text { distance } \\
\text { covered by } \\
\text { players at }\end{array}$ \\
\hline
\end{tabular}




\begin{tabular}{|l|l|l|l|}
\hline & $\begin{array}{l}\text { Strong, } \\
\text { medium } \\
\text { and weak }\end{array}$ & & $\begin{array}{l}\text { different } \\
\text { intensities } \\
\text { during the } \\
\text { effective time } \\
\text { of play was } \\
\text { higher when } \\
\text { playing at } \\
\text { home, when } \\
\text { the reference } \\
\text { team was } \\
\text { losing and } \\
\text { when the } \\
\text { opponent } \\
\text { team was } \\
\end{array}$ \\
& strong. \\
\hline
\end{tabular}

These research papers mostly show that there are high-intensity activity patterns in elite domestic and elite international players. The soccer players were assessed by the $10-\mathrm{x} 5$-m shuttle run test $(10 \times 5$ SRT) on a soccer field in a soccer season. These studies also showed that there are differences between different competitive levels. The professional players who play for more successful teams cover greater total distances with the ball and at very high-intensity running, have a higher average number of goals for total shots on target, higher number of passes, tackles, dribbling and shots on target compared to less successful teams. [4]

There are also studies that focus on the fatigue of the players and the effect of substitutions. These studies show that the performance of players does not change with the short recovery between matches. Di Salvo et al [5] use factorial linear mixed modeling to show the intensity activity of players is related to the position they play. Christopher Carling [6] used Friedman's 
repeated-measures analysis of variance on ranks test to assess differences in means in performance measures across separate time intervals. Followup univariate analyses using Tukey pairwise multiple comparison procedures were performed where appropriate. By using tracking data , they show that the covered distance during different periods of the match was higher in the first half than second half of a match. But the skill-related measures revealed no significant decline between halves. Also analysis of players' performance suggested that their performance did not change when competing in successive matches within a short time period. Lyons et al [7] mostly focused on predicting and finding the most effective way of playing, using multidimensional data instead of just onedimensional data.

Albin Tenga et al [8], using Norwegian elite soccer matches, were trying to examine the effect of playing tactics on achieving score-box possession by assessing opponent interactions. Using multiple logistic regression, they found that, for the main variable "team possession type", counterattacks were more effective than elaborate attacks when playing against an imbalanced defence (odds ratio: 2.69; 95\% confidence interval: 1.64 to 4.43) but not against a balanced defence (odds ratio: 1.14; 95\% confidence interval: 0.47 to 2.76 ).

Other studies examined, for each team, ball possession and the probability of scoring a goal. The first of these studies was by Reep et al [9], followed by 
the work of Mike Hughes et al [10], which was influenced by the earlier work of Reep and Benjamin [11]. But instead of finding how to score or how the goals were scored, Mike Hughes et al looked into the passing and shots in the soccer game and their effect on the quality and quantity of scoring.

The study by Carlos Lago-Peñas et al [12] identified the soccer gamerelated statistics that best discriminated home and visiting teams according to team quality.

Using the Kolmogorov-Smirnov test, only the variables possession, gains of possession and losses of possession were found to follow a Normal distribution. They used either a t-test or a Mann-Whitney U test, depending on the variable distribution, to identify univariate differences between the game-related statistics of home and away teams.

Using discriminant analysis, they were able to identify variables useful for discriminating between winning, drawing, and losing teams. They used all the games in 2008-2009 season of the Spanish pro league (380 matches). They used variables such as: total shots, shots on goal, effectiveness (Effectiveness=Shots on goal $\times 100 /$ Total shots), assists, crosses, offsides committed and received, corners, ball possession, crosses against, fouls committed and received, corners against, yellow and red cards, and venue. They used univariate (t-test) and multivariate (discriminant) analyses of data and concluded that winning teams had averages that were significantly higher for the following game statistics: total shots $(\mathrm{p}<$ 
$0.001)$, shots on goal $(p<0.01)$, effectiveness $(p<0.01)$, assists $(p<0.01)$, off-sides committed $(p<0.01)$, and crosses against $(p<0.01)$. Losing teams had significantly higher averages for the variables crosses $(p<0.01)$, off-sides received $(p<0.01)$, and red cards $(p<0.01)$. Using discriminant analysis, they concluded the following: the variables that discriminate between winning, drawing, and losing teams were the total shots, shots on goal, crosses, crosses against, ball possession and venue. [13] Utilizing data from the 2001-2002 FA Premiership season, Horn et al [14] found that, for the central area just outside the penalty area, $86 \%$ of the passes in this area go to the penalty area and therefore result in a shooting opportunity. In a similar study, Taylor and Williams [15] found how important it was in the 2002 World Cup finals for the winning side to retain possession. They reported that gaining possession in the defensive area resulted in more attempts on the goal, which was related to more goals and in a way means better defending and not giving the opponents the opportunity to score or attempt to score a goal.

In a similar study, Pollard [16] defined a variable called "Yield" which represents the number of actions that were successfully performed in the match. It was suggested that unsuccessful teams have a lower yield attribute. However, this variable is not very reliable for a soccer match, where the result of the entire game can turn at the last minute just by a mistake. 
Another article by Carlos Lago-Peñas and Alexandre Dellal [17] studied how longer possession time can result in more scoring and therefore result in winning. A standard multiple regression was used to examine how much ball possession was explained by contextual variables (match status, match location, quality of opposition and by the level of the team.

In a study on the performance of players, Radu S. Tunaru et al [18] examined how the form of a player can affect winning the Premier league championship in season 2003-2004. In this study they used an Opta Index [1] for the players and showed how the transfer value of Thiery Henry, who was playing for Arsenal in the 2003-4 season, changed throughout the season and how his performance affected his market value, as shown in Figures 1 and 2. 


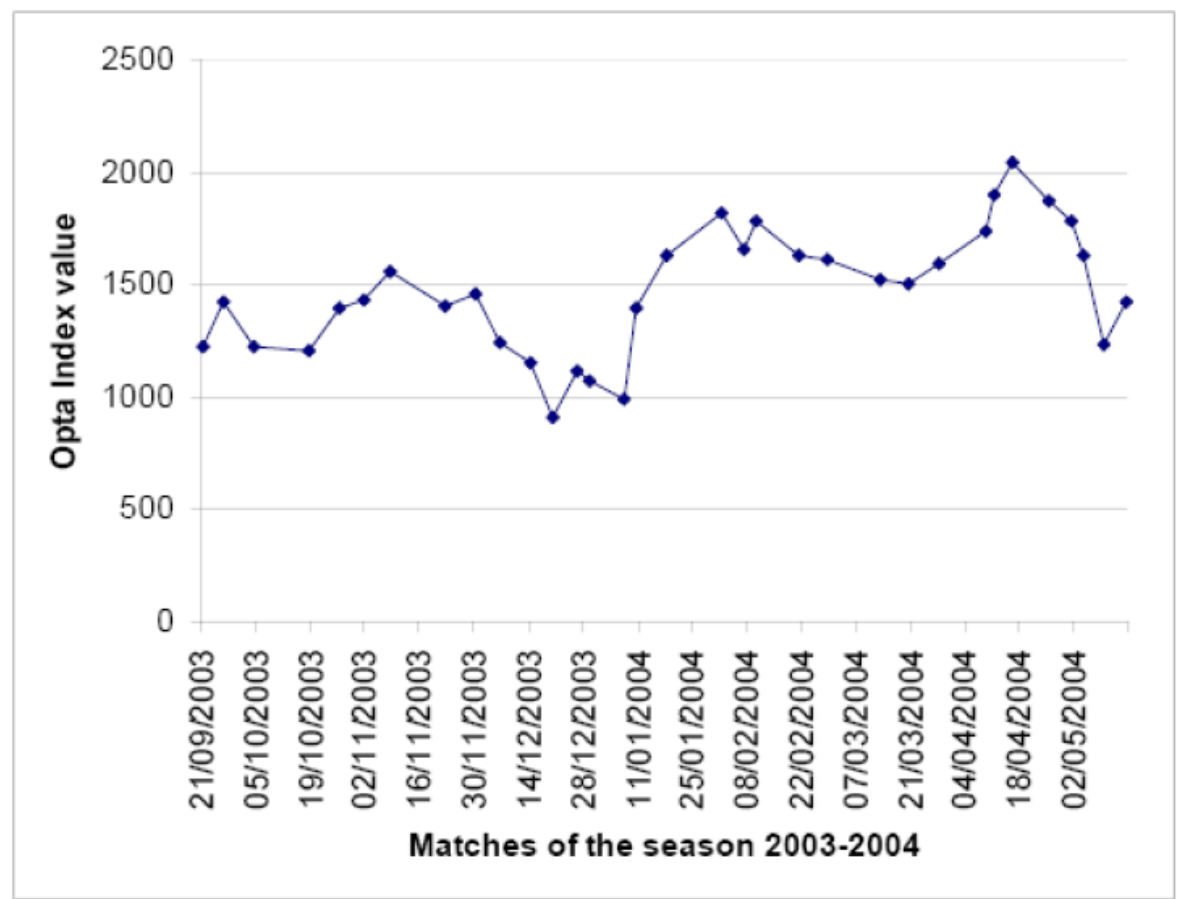

Figure 1: Opta Index Scores for Thierry Henry over season 2003-04 when playing for Arsenal Football Club [18]

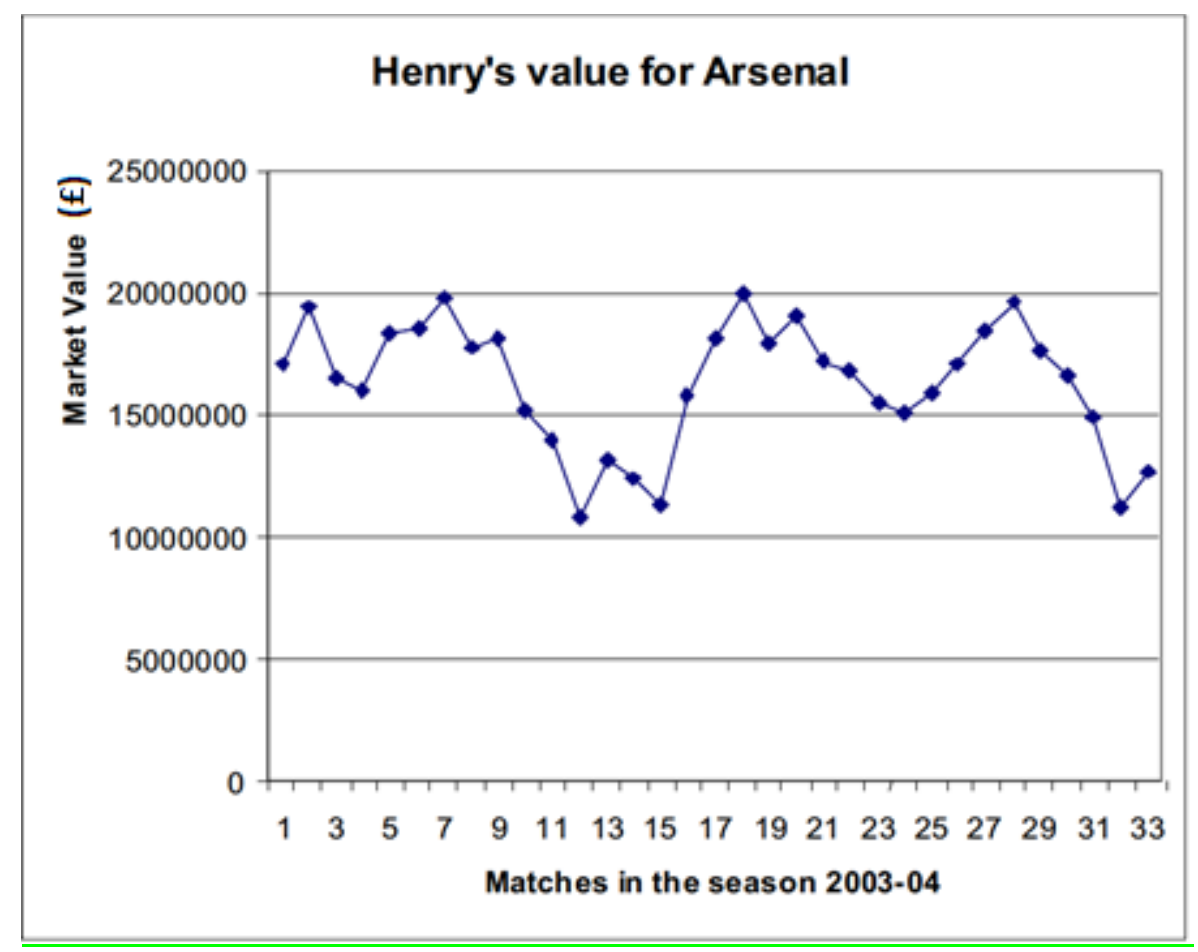

Figure 2: The evolution of Thierry Henry's financial value over season 2003-04 [18] 
In the same study [18] they noted the number of injured players the rivals of Arsenal for the championship- Manchester United (ManU)- had for that season. It is very clear that, for the second half of the season, ManU's number of injured players was high. Thus it was possible that, along with the Thiery Henry's form for the second part of the season, another reason that ManU could not compete with Arsenal and lost the championship was their high number of injured players together with not having good substitutes to play in the injured players' positions [18]. Figure 2 shows the player's market value after each game he played in that season. Figure 1 and Figure 2 are not necessarily correlated but when his Opta index is high, his market value increased as well.

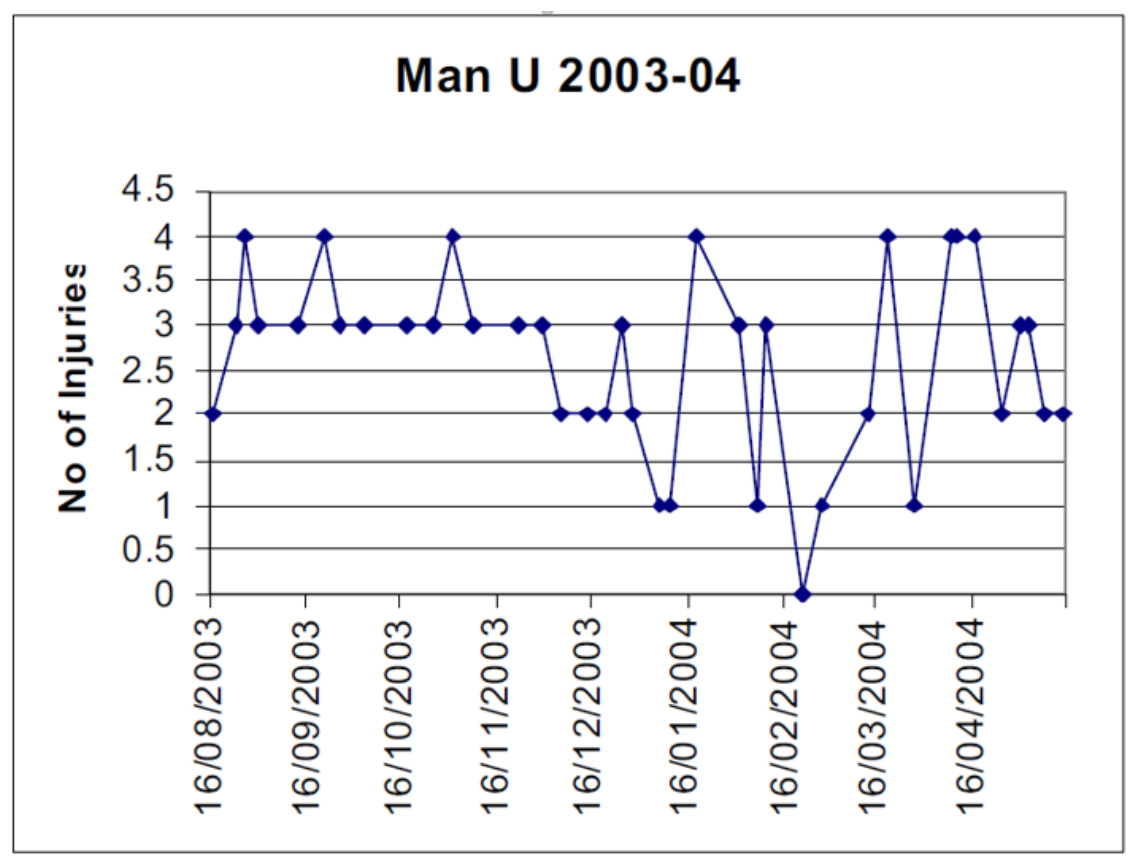

Figure 3: The evolution of injuries for Manchester United in season 2003-04 


\section{Study Data and Exploratory Data Analyses}

\subsection{Data}

Data for this thesis was gathered from the official Italian League Website [2]. The data set used was for the 2015-16 season for the professional Italian football league known as Serie A. There were 591 players listed on 20 different teams playing in the league. They played 38 games throughout the entire season - 19 games at home and 19 away games. The information

included time spent on the field for each game throughout the season for all the players that played in the Italian professional Serie A league in the season of 2015-16. Other information that was included were Assists, Goals scored, Position of the players, Yellow cards, Red cards, Clean sheet, Win/Lose/Draw table, and the result of the games.

\subsubsection{Definition of the Variables}

Assists are recorded for the last player who passed the ball for the goal scorer to score a goal.

Clean sheet means a team does not concede any goals in a match.

Positions are divided into Defence, Midfielder, and Striker.

Yellow cards and Red cards: Yellow cards represent a warning. If a player gets two yellow cards in one match, it becomes a red card and the player 
must leave the field; their team must play the rest of the game with a player short. a direct red card is when the foul is usually harsh and harmful to the other player. In the data sets made for the yellow card and red card, we have been combined results in such a way that if a player gets a red card without getting a yellow card, instead of recording a one in the yellow card column, a two was entered in the table since two yellow cards have the same weight as one red card.

\subsubsection{Structure of the Data Sets}

The datasets for Clean sheet, Yellow cards and Red cards, Time played, Goals Scored and Assists had the same structure. The first column was the name of the player, the second column was the team they played on, and the rest of the columns are the teams that they played against in the season. For instance, for the Time Played Table, the numbers represent the minutes played by a player in each game. 


\subsubsection{Data Wrangling}

The first table that needed preparation was the Results table. The Results table has the form below:

Table 5:The structure of Results table

\begin{tabular}{|llll|}
\hline & A & B & C \\
\hline A & & Number-Number & Number-Number \\
\hline B & Number-Number & & Number-Number \\
\hline C & Number-Number & Number-Number & \\
\hline
\end{tabular}

$\mathrm{A}, \mathrm{B}$ and $\mathrm{C}$ are the names of the teams. For any game, the column represents the home team and the row represents the away team. The first number is the number of goals that the home team scored, and the second number is the number of goals that the away team scored.

Based on the Results table, a few other tables were generated. The Win/Lose/Draw table and the Clean Sheet table were generated from this table. The Win/Lose/Draw table was made based on the difference of the two numbers in Table 5. A positive number means that the home team won the game, a negative means the away team won the game, and zero means that the game was a tie. For a win, all the winning players in that match were assigned a value of one, for a loss they were assigned -1 , and for a draw they were assigned zero. 
As explained earlier, if a team does not concede any goals in a match they have a clean sheet. If they had a clean sheet, in the Clean Sheet table, all the players on that team were assigned a value of 1 , otherwise they are assigned a value of zero.

Before starting work with the data, some minor changes had to be made. There were some players on the squad for each team that never got the chance to play at any time in the entire season therefore, all the variables for those players were zero. As a result, these players were removed from the data set.

\subsection{Exploratory Data Analyses}

\subsubsection{Descriptive Statistics}

The team with the largest number of Clean sheets (CS) was Juventus (22 games out of 38 games); Napoli and Fiorentina (with 15 and 14 Clean sheets, respectively) were next highest. It must be noted that, in the 201516 season, Juventus won the league and Napoli was in second place.

For each position, the list of the Top Ten players is presented, based on each variable. 


\subsubsection{Defenders}

In the following tables, the top 10 defenders based on each of: time played, number of assists, number of goals, and warning cards are shown.

Time played

Table 6:Top Ten Defenders - playing time

\begin{tabular}{|l|l|l|l|l|l|l|l|}
\hline \multicolumn{2}{|c|}{ Player } & Team & $\begin{array}{l}\text { Overall } \\
\text { CS }\end{array}$ & $\begin{array}{l}\text { Overall } \\
\text { Assists }\end{array}$ & $\begin{array}{l}\text { Overall } \\
\text { Cards }\end{array}$ & $\begin{array}{l}\text { Overall } \\
\text { Goals }\end{array}$ & $\begin{array}{l}\text { Overall } \\
\text { Time }\end{array}$ \\
\hline $\mathbf{1}$ & ELSEID HYSAJ & Napoli & 15 & 2 & 5 & 0 & 3441 \\
\hline $\mathbf{2}$ & FRANCESCO ACERBI & Sassuolo & 11 & 0 & 3 & 4 & 3426 \\
\hline $\mathbf{3}$ & MARIO RUI & Empoli & 12 & 2 & 8 & 0 & 3425 \\
\hline $\mathbf{4}$ & RAUL ALBIOL & Napoli & 15 & 1 & 10 & 1 & 3408 \\
\hline $\mathbf{5}$ & L. BONUCCI & $\begin{array}{l}\text { JUVENT } \\
\text { US }\end{array}$ & 22 & 1 & 6 & 2 & 3325 \\
\hline $\mathbf{6}$ & $\begin{array}{l}\text { GIANCARLO } \\
\text { GONZALEZ }\end{array}$ & Palermo & 10 & 0 & 10 & 0 & 3311 \\
\hline $\mathbf{7}$ & GONZALO RODRIGUEZ & Fiorentin & 14 & 0 & 7 & 4 & 3309 \\
\hline $\mathbf{8}$ & EMILIANO MORETTI & Torino & 6 & 1 & 4 & 1 & 3268 \\
\hline $\mathbf{9}$ & FEDERICO PELUSO & Sassuolo & 11 & 1 & 11 & 1 & 3237 \\
\hline $\mathbf{1 0}$ & SIME VRSALJKO & Sassuolo & 11 & 4 & 10 & 0 & 3226 \\
\hline
\end{tabular}

Goals

Table 7:Top Ten players with highest number of Goals

\begin{tabular}{|l|l|l|l|l|l|l|l|}
\hline \multicolumn{2}{|c|}{ Player } & Team & $\begin{array}{l}\text { Overall } \\
\text { clean } \\
\text { sheet }\end{array}$ & $\begin{array}{l}\text { Overall } \\
\text { Assist }\end{array}$ & $\begin{array}{l}\text { Overall } \\
\text { Cards }\end{array}$ & $\begin{array}{l}\text { Overall } \\
\text { Goals }\end{array}$ & $\begin{array}{l}\text { Overall } \\
\text { Time }\end{array}$ \\
\hline $\mathbf{1}$ & $\begin{array}{l}\text { EROS } \\
\text { PISANO }\end{array}$ & Verona & 0 & 0 & 6 & 5 & 3069 \\
\hline $\mathbf{2}$ & $\begin{array}{l}\text { FRANCESCO } \\
\text { ACERBI }\end{array}$ & Sassuolo & 11 & 0 & 3 & 4 & 3426 \\
\hline
\end{tabular}




\begin{tabular}{|l|l|l|l|l|l|l|l|}
\hline $\mathbf{3}$ & $\begin{array}{l}\text { GONZALO } \\
\text { RODRIGUEZ }\end{array}$ & Fiorentina & 14 & 0 & 7 & 4 & 3309 \\
\hline $\mathbf{4}$ & L.DIGNE & Roma & 8 & 3 & 4 & 3 & 2924 \\
\hline $\mathbf{5}$ & $\begin{array}{l}\text { LEONARDO } \\
\text { BLANCHARD }\end{array}$ & Frosinone & 7 & 1 & 4 & 3 & 2577 \\
\hline $\mathbf{6}$ & $\begin{array}{l}\text { LUCA } \\
\text { ROSSETTINI }\end{array}$ & Bologna & 13 & 1 & 12 & 3 & 2686 \\
\hline $\mathbf{7}$ & $\begin{array}{l}\text { LUCA } \\
\text { ANTONELLI }\end{array}$ & Milan & 11 & 1 & 5 & 3 & 2483 \\
\hline $\mathbf{8}$ & $\begin{array}{l}\text { ALEX } \\
\mathbf{9}\end{array}$ & $\begin{array}{l}\text { MARCOS } \\
\text { ALONSO }\end{array}$ & Fiorentina & 14 & 4 & 8 & 3 \\
\hline $\mathbf{1 0}$ & $\begin{array}{l}\text { ERVIN } \\
\text { ZUKANOVIC }\end{array}$ & Sampdoria & 7 & 0 & 6 & 3 & 2479 \\
\hline
\end{tabular}

Overall Assists

Table 8:Top Ten players with Assists

\begin{tabular}{|c|c|c|c|c|c|c|c|}
\hline & Player & Team & $\begin{array}{l}\text { Overall } \\
\text { Clean } \\
\text { Sheet }\end{array}$ & $\begin{array}{l}\text { Overall } \\
\text { Assist }\end{array}$ & $\begin{array}{l}\text { Overall } \\
\text { Cards }\end{array}$ & $\begin{array}{l}\text { Overall } \\
\text { Goals }\end{array}$ & $\begin{array}{l}\text { Overall } \\
\text { Time }\end{array}$ \\
\hline 1 & $\begin{array}{l}\text { CRISTIAN } \\
\text { ANSALDI }\end{array}$ & Genoa & 12 & 4 & 4 & 0 & 2132 \\
\hline 2 & $\begin{array}{l}\text { DANIEL } \\
\text { PAVLOVIC }\end{array}$ & Frosinone & 7 & 4 & 5 & 0 & 2036 \\
\hline 3 & $\begin{array}{l}\text { SIME } \\
\text { VRSALJKO }\end{array}$ & Sassuolo & 11 & 4 & 10 & 0 & 3226 \\
\hline 4 & $\begin{array}{l}\text { BRUNO } \\
\text { PERES }\end{array}$ & Torino & 6 & 4 & 9 & 2 & 2745 \\
\hline 5 & $\begin{array}{l}\text { ANDREA } \\
\text { RISPOLI }\end{array}$ & Palermo & 10 & 4 & 2 & 0 & 1511 \\
\hline 6 & $\begin{array}{l}\text { MARCOS } \\
\text { ALONSO }\end{array}$ & Fiorentina & 14 & 4 & 8 & 3 & 2479 \\
\hline 7 & L.DIGNE & Roma & 8 & 3 & 4 & 3 & 2924 \\
\hline 8 & $\begin{array}{l}\text { FABRIZIO } \\
\text { CACCIATORE }\end{array}$ & Chievo & 12 & 3 & 6 & 1 & 2444 \\
\hline 9 & $\begin{array}{l}\text { FAOUZI } \\
\text { GHOULAM }\end{array}$ & Napoli & 15 & 3 & 3 & 0 & 3066 \\
\hline 10 & $\begin{array}{l}\text { ADAM } \\
\text { MASINA }\end{array}$ & Bologna & 13 & 3 & 10 & 2 & 2820 \\
\hline
\end{tabular}


Table 9:Top Ten Defenders with highest number of warning cards

\begin{tabular}{|c|c|c|c|c|c|c|c|}
\hline & Player & Team & $\begin{array}{c}\text { Overal } \\
\text { I clean } \\
\text { sheet }\end{array}$ & $\begin{array}{l}\text { Overal } \\
\text { I assist }\end{array}$ & $\begin{array}{l}\text { Overal } \\
\text { l cards }\end{array}$ & $\begin{array}{l}\text { Over } \\
\text { all } \\
\text { Goal }\end{array}$ & $\begin{array}{l}\text { Ove } \\
\text { rall } \\
\text { time }\end{array}$ \\
\hline 1 & MAURICIO & LAZIO & 12 & 0 & 15 & 0 & 2050 \\
\hline 2 & $\begin{array}{l}\text { LARANGEIRA } \\
\text { DANILO }\end{array}$ & UDINESE & 9 & 0 & 13 & 0 & 3122 \\
\hline 3 & FELIPE & UDINESE & 9 & 1 & 13 & 1 & 2241 \\
\hline 4 & $\begin{array}{l}\text { LEONARDO } \\
\text { BLANCHARD }\end{array}$ & $\begin{array}{l}\text { FROSINON } \\
\text { E }\end{array}$ & 7 & 1 & 12 & 3 & 2577 \\
\hline 5 & ALJAZ STRUNA & PALERMO & 10 & 0 & 12 & 1 & 1915 \\
\hline 6 & $\begin{array}{l}\text { BOSTJAN } \\
\text { CESAR }\end{array}$ & CHIEVO & 12 & 0 & 11 & 1 & 2870 \\
\hline 7 & $\begin{array}{l}\text { KALIDOU } \\
\text { KOULIBALY }\end{array}$ & NAPOLI & 15 & 0 & 11 & 0 & 3039 \\
\hline 8 & $\begin{array}{l}\text { FEDERICO } \\
\text { PELUSO }\end{array}$ & $\begin{array}{l}\text { SASSUOL } \\
\mathrm{O}\end{array}$ & 11 & 1 & 11 & 1 & 3237 \\
\hline 9 & KAMIL GLIK & TORINO & 6 & 0 & 11 & 0 & 3162 \\
\hline 10 & $\begin{array}{l}\text { RICCARDO } \\
\text { GAGLIOLO }\end{array}$ & CARPI & 8 & 0 & 11 & 1 & 2792 \\
\hline
\end{tabular}

\subsubsection{Midfielders}

In the following tables the top 10 Midfielders based on: time played on the

field, number of assists, number of goals, warning cards are displayed. 
Time played

Table 10:Top Ten Midfielders based on time on the field

\begin{tabular}{|c|c|c|c|c|c|c|c|}
\hline \multicolumn{2}{|r|}{ Player } & Team & $\begin{array}{l}\text { Overal } \\
\text { I clean } \\
\text { sheet }\end{array}$ & $\begin{array}{l}\text { Over } \\
\text { all } \\
\text { assist } \\
\text { ss }\end{array}$ & $\begin{array}{l}\text { Over } \\
\text { all } \\
\text { cards }\end{array}$ & $\begin{array}{l}\text { Over } \\
\text { all } \\
\text { Goal }\end{array}$ & $\begin{array}{l}\text { Over } \\
\text { all } \\
\text { time }\end{array}$ \\
\hline 1 & MAREK HAMSIK & NAPOLI & 15 & 11 & 0 & 6 & 3362 \\
\hline 2 & $\begin{array}{l}\text { FRANCO } \\
\text { VAZQUEZ }\end{array}$ & PALERMO & 10 & 7 & 11 & 8 & 3343 \\
\hline 3 & $\begin{array}{l}\text { MARTEN DE } \\
\text { ROON }\end{array}$ & ATALANTA & 11 & 2 & 11 & 1 & 3270 \\
\hline 4 & DIEGO LAXALT & GENOA & 12 & 4 & 3 & 3 & 3261 \\
\hline 5 & $\begin{array}{l}\text { FRANCESCO } \\
\text { MAGNANELLI }\end{array}$ & SASSUOLO & 11 & 1 & 8 & 1 & 3241 \\
\hline 6 & P. POGBA & JUVENTUS & 22 & 12 & 10 & 8 & 3184 \\
\hline 7 & PIOTR ZIELINSKI & EMPOLI & 12 & 4 & 7 & 5 & 3175 \\
\hline 8 & BORJA VALERO & FIORE & 14 & 6 & 5 & 5 & 3157 \\
\hline 9 & TOMAS RINCON & GENOA & 12 & 5 & 9 & 3 & 3102 \\
\hline 10 & $\begin{array}{l}\text { RADJA } \\
\text { NAINGGOLAN }\end{array}$ & ROMA & 8 & 1 & 12 & 7 & 3084 \\
\hline
\end{tabular}

Goals

Table 11:Top Ten Midfielders with highest number of Goals

\begin{tabular}{|c|c|c|c|c|c|c|c|}
\hline & Players & Team & $\begin{array}{c}\text { Overall } \\
\text { clean } \\
\text { sheet }\end{array}$ & $\begin{array}{l}\text { Over } \\
\text { all } \\
\text { assist }\end{array}$ & $\begin{array}{l}\text { Over } \\
\text { all } \\
\text { cards }\end{array}$ & $\begin{array}{l}\text { Over } \\
\text { all } \\
\text { Goal }\end{array}$ & $\begin{array}{l}\text { Over } \\
\text { all } \\
\text { time }\end{array}$ \\
\hline 1 & JOSIP ILICIC & FIORE & 14 & 5 & 2 & 13 & 1984 \\
\hline 2 & $\begin{array}{l}\text { MIRALEM } \\
\text { PJANIC }\end{array}$ & ROMA & 8 & 12 & 12 & 9 & 2700 \\
\hline 3 & $\begin{array}{l}\text { FRANCO } \\
\text { VAZQUEZ }\end{array}$ & PALERMO & 10 & 7 & 11 & 8 & 3343 \\
\hline 4 & $\begin{array}{l}\text { ROBERTO } \\
\text { SORIANO }\end{array}$ & SAMP & 7 & 4 & 7 & 8 & 2953 \\
\hline 5 & P. POGBA & JUVENTUS & 22 & 12 & 10 & 8 & 3184 \\
\hline 6 & $\begin{array}{l}\text { ALESSANDRO } \\
\text { FLORENZI }\end{array}$ & ROMA & 8 & 3 & 4 & 7 & 2865 \\
\hline
\end{tabular}




\begin{tabular}{|r|l|l|r|r|r|r|r|}
\hline $\mathbf{7}$ & $\begin{array}{l}\text { RADJA } \\
\text { NAINGGOLAN }\end{array}$ & ROMA & 8 & 1 & 12 & 7 & 3084 \\
\hline $\mathbf{8}$ & $\begin{array}{l}\text { EMANUELE } \\
\text { GIACCHERINI }\end{array}$ & BOLOGNA & 13 & 0 & 7 & 7 & 2288 \\
\hline $\mathbf{9}$ & $\begin{array}{l}\text { VALTER } \\
\text { BIRSA }\end{array}$ & CHIEVO & 12 & 7 & 4 & 6 & 2401 \\
\hline $\mathbf{1 0}$ & SUSO & GENOA & 12 & 1 & 4 & 6 & 1211 \\
\hline
\end{tabular}

Overall Assists

Table 12:Top Ten Midfielders based on Assists

\begin{tabular}{|c|c|c|c|c|c|c|c|}
\hline \multicolumn{2}{|r|}{ Player } & Team & $\begin{array}{l}\text { Over } \\
\text { all } \\
\text { clean } \\
\text { sheet }\end{array}$ & $\begin{array}{l}\text { Over } \\
\text { all } \\
\text { assist }\end{array}$ & $\begin{array}{l}\text { Over } \\
\text { all } \\
\text { cards }\end{array}$ & $\begin{array}{c}\text { Over } \\
\text { all } \\
\text { Goal }\end{array}$ & $\begin{array}{c}\text { Over } \\
\text { all } \\
\text { time }\end{array}$ \\
\hline 1 & $\begin{array}{l}\text { MIRALEM } \\
\text { PJANIC }\end{array}$ & ROMA & 8 & 12 & 12 & 9 & 2700 \\
\hline 2 & P. POGBA & JUVENTUS & 22 & 12 & 10 & 8 & 3184 \\
\hline 3 & $\begin{array}{l}\text { MAREK } \\
\text { HAMSIK }\end{array}$ & NAPOLI & 15 & 11 & 0 & 6 & 3362 \\
\hline 4 & $\begin{array}{l}\text { RICCARDO } \\
\text { SAPONARA }\end{array}$ & EMPOLI & 12 & 10 & 8 & 5 & 2719 \\
\hline 5 & $\begin{array}{l}\text { BONAVENTUR } \\
\text { A }\end{array}$ & MILAN & 11 & 8 & 7 & 6 & 2811 \\
\hline 6 & VALTER BIRSA & CHIEVO & 12 & 7 & 4 & 6 & 2401 \\
\hline 7 & $\begin{array}{l}\text { FRANCO } \\
\text { VAZQUEZ }\end{array}$ & PALERMO & 10 & 7 & 11 & 8 & 3343 \\
\hline 8 & $\begin{array}{l}\text { BORJA } \\
\text { VALERO }\end{array}$ & FIORE & 14 & 6 & 5 & 5 & 3157 \\
\hline 9 & $\begin{array}{l}\text { FEDERICO } \\
\text { VIVIANI }\end{array}$ & Verona & 0 & 6 & 6 & 3 & 1688 \\
\hline 10 & $\begin{array}{l}\text { TOMAS } \\
\text { RINCON }\end{array}$ & GENOA & 12 & 5 & 9 & 3 & 3102 \\
\hline
\end{tabular}


Table 13:Top Ten Midfielders with highest number of warning cards

\begin{tabular}{|c|c|c|c|c|c|c|c|}
\hline \multicolumn{2}{|r|}{ Player } & Team & $\begin{array}{l}\text { Over } \\
\text { all } \\
\text { clean } \\
\text { sheet }\end{array}$ & $\begin{array}{l}\text { Over } \\
\text { all } \\
\text { assist }\end{array}$ & $\begin{array}{l}\text { Over } \\
\text { all } \\
\text { cards }\end{array}$ & $\begin{array}{l}\text { Over } \\
\text { all } \\
\text { Goal }\end{array}$ & $\begin{array}{l}\text { Over } \\
\text { all } \\
\text { time }\end{array}$ \\
\hline 1 & $\begin{array}{l}\text { LORENZO } \\
\text { LOLLO }\end{array}$ & CARPI & 8 & 1 & 14 & 3 & 2223 \\
\hline 2 & FERNANDO & SAMP & 7 & 2 & 14 & 4 & 3054 \\
\hline 3 & $\begin{array}{l}\text { MIRALEM } \\
\text { PJANIC }\end{array}$ & ROMA & 8 & 12 & 12 & 9 & 2700 \\
\hline 4 & $\begin{array}{l}\text { RADJA } \\
\text { NAINGGOLA } \\
\mathrm{N}\end{array}$ & ROMA & 8 & 1 & 12 & 7 & 3084 \\
\hline 5 & JORGINHO & NAPOLI & 15 & 4 & 12 & 0 & 3051 \\
\hline 6 & MIRKO GORI & FROSINONE & 7 & 0 & 11 & 0 & 2269 \\
\hline 7 & $\begin{array}{l}\text { DANILO } \\
\text { SODDIMO }\end{array}$ & FROSINONE & 7 & 2 & 11 & 1 & 1886 \\
\hline 8 & $\begin{array}{l}\text { AMADOU } \\
\text { DIAWARA }\end{array}$ & BOLOGNA & 13 & 1 & 11 & 0 & 2897 \\
\hline 9 & $\begin{array}{l}\text { MARTEN DE } \\
\text { ROON }\end{array}$ & ATALANTA & 11 & 2 & 11 & 1 & 3270 \\
\hline 10 & $\begin{array}{l}\text { GIUSEPPE } \\
\text { VIVES }\end{array}$ & TORINO & 6 & 1 & 11 & 1 & 2709 \\
\hline
\end{tabular}

\subsubsection{Strikers}

In the following, the top 10 Strikers based on: time played on the field, number of assists, number of goals, and warning cards are shown. 
Time played

Table 14:Top Ten Forwards based on time on the field

\begin{tabular}{|c|c|c|c|c|c|c|c|}
\hline \multicolumn{2}{|c|}{ Player } & Team & $\begin{array}{c}\text { Overall } \\
\text { clean } \\
\text { sheet }\end{array}$ & $\begin{array}{l}\text { Over } \\
\text { all } \\
\text { assist }\end{array}$ & $\begin{array}{l}\text { Over } \\
\text { all } \\
\text { cards }\end{array}$ & $\begin{array}{l}\text { Over } \\
\text { all } \\
\text { Goal }\end{array}$ & $\begin{array}{l}\text { Over } \\
\text { all } \\
\text { time }\end{array}$ \\
\hline 1 & $\begin{array}{l}\text { CARLOS } \\
\text { BACCA }\end{array}$ & MILAN & 11 & 2 & 2 & 18 & 3316 \\
\hline 2 & $\begin{array}{l}\text { MANUEL } \\
\text { PUCCIARELLI }\end{array}$ & EMPOLI & 12 & 3 & 2 & 6 & 3220 \\
\hline 3 & $\begin{array}{l}\text { GONZALO } \\
\text { HIGUAIN }\end{array}$ & NAPOLI & 15 & 2 & 3 & 36 & 3090 \\
\hline 4 & $\begin{array}{l}\text { DANIEL } \\
\text { CIOFANI }\end{array}$ & $\begin{array}{l}\text { FROSINON } \\
\text { E }\end{array}$ & 7 & 1 & 1 & 9 & 3039 \\
\hline 5 & $\begin{array}{l}77 \text { CYRIL } \\
\text { THEREAU }\end{array}$ & UDINESE & 9 & 3 & 4 & 11 & 2950 \\
\hline 6 & $\begin{array}{l}\text { ALEJANDRO } \\
\text { GOMEZ }\end{array}$ & $\begin{array}{l}\text { ATALANT } \\
\text { A }\end{array}$ & 11 & 7 & 6 & 7 & 2946 \\
\hline 7 & $\begin{array}{l}\text { JOSE' } \\
\text { CALLEJON }\end{array}$ & NAPOLI & 15 & 7 & 4 & 7 & 2934 \\
\hline 8 & $\begin{array}{l}\text { MOHAMED } \\
\text { SALAH }\end{array}$ & ROMA & 8 & 6 & 3 & 13 & 2838 \\
\hline 9 & $\begin{array}{l}\text { MASSIMO } \\
\text { MACCARONE }\end{array}$ & EMPOLI & 12 & 5 & 4 & 13 & 2778 \\
\hline 10 & $\begin{array}{l}\text { NIKOLA } \\
\text { KALINIC }\end{array}$ & FIORE & 14 & 3 & 5 & 12 & 2727 \\
\hline
\end{tabular}

Goals

Table 15:Top Ten Forwards based on Goals scored

\begin{tabular}{|c|c|c|c|c|c|c|c|}
\hline \multicolumn{2}{|r|}{ Player } & Team & $\begin{array}{l}\text { Over } \\
\text { all } \\
\text { clean } \\
\text { sheet }\end{array}$ & $\begin{array}{l}\text { Over } \\
\text { all } \\
\text { assist }\end{array}$ & $\begin{array}{l}\text { Over } \\
\text { all } \\
\text { cards }\end{array}$ & $\begin{array}{l}\text { Over } \\
\text { all } \\
\text { Goal }\end{array}$ & $\begin{array}{l}\text { Over } \\
\text { all } \\
\text { time }\end{array}$ \\
\hline 1 & $\begin{array}{l}\text { GONZALO } \\
\text { HIGUAIN }\end{array}$ & NAPOLI & 15 & 2 & 3 & 36 & 3090 \\
\hline 2 & P. DYBALA & JUVENTUS & 22 & 9 & 1 & 19 & 2547 \\
\hline 3 & $\begin{array}{l}\text { CARLOS } \\
\text { BACCA }\end{array}$ & MILAN & 11 & 2 & 2 & 18 & 3316 \\
\hline 4 & $\begin{array}{l}\text { MAURO } \\
\text { ICARDI }\end{array}$ & INTER & 15 & 4 & 1 & 16 & 2699 \\
\hline 5 & $\begin{array}{l}\text { LEONARDO } \\
\text { PAVOLETTI }\end{array}$ & GENOA & 12 & 3 & 5 & 14 & 2118 \\
\hline 6 & $\begin{array}{l}\text { MOHAMED } \\
\text { SALAH }\end{array}$ & ROMA & 8 & 6 & 3 & 13 & 2838 \\
\hline
\end{tabular}




\begin{tabular}{|r|l|l|r|r|r|r|r|}
\hline $\mathbf{7}$ & $\begin{array}{l}\text { MASSIMO } \\
\text { MACCARON } \\
\text { E EMPOLI }\end{array}$ & 12 & 5 & 4 & 13 & 2778 \\
\hline $\mathbf{8}$ & $\begin{array}{l}\text { LORENZO } \\
\text { INSIGNE }\end{array}$ & NAPOLI & 15 & 10 & 2 & 12 & 2682 \\
\hline $\mathbf{9}$ & $\begin{array}{l}\text { ANDREA } \\
\text { BELOTTI }\end{array}$ & TORINO & 6 & 4 & 4 & 12 & 2646 \\
\hline $\mathbf{1 0}$ & $\begin{array}{l}\text { NIKOLA } \\
\text { KALINIC }\end{array}$ & FIORE & 14 & 3 & 5 & 12 & 2727 \\
\hline
\end{tabular}

Overall Assists

Table 16:Top Ten Forwards based on Assists

\begin{tabular}{|c|c|c|c|c|c|c|c|}
\hline & Player & Team & $\begin{array}{c}\text { Overall } \\
\text { clean } \\
\text { sheet }\end{array}$ & $\begin{array}{l}\text { Over } \\
\text { all } \\
\text { assist }\end{array}$ & $\begin{array}{l}\text { Over } \\
\text { all } \\
\text { cards }\end{array}$ & $\begin{array}{l}\text { Over } \\
\text { all } \\
\text { Goal }\end{array}$ & $\begin{array}{l}\text { Over } \\
\text { all } \\
\text { time }\end{array}$ \\
\hline 1 & $\begin{array}{l}\text { LORENZO } \\
\text { INSIGNE }\end{array}$ & NAPOLI & 15 & 10 & 2 & 12 & 2682 \\
\hline 2 & P. DYBALA & JUVENTUS & 22 & 9 & 1 & 19 & 2547 \\
\hline 3 & D.PEROTTI & ROMA & 8 & 7 & 2 & 3 & 1275 \\
\hline 4 & $\begin{array}{l}\text { RICCARDO } \\
\text { MEGGIORI } \\
\text { NI }\end{array}$ & CHIEVO & 12 & 7 & 10 & 5 & 1712 \\
\hline 5 & $\begin{array}{l}\text { JOSE' } \\
\text { CALLEJON }\end{array}$ & NAPOLI & 15 & 7 & 4 & 7 & 2934 \\
\hline 6 & $\begin{array}{l}\text { ALEJANDR } \\
\text { O GOMEZ }\end{array}$ & ATALANTA & 11 & 7 & 6 & 7 & 2946 \\
\hline 7 & $\begin{array}{l}\text { MIROSLAV } \\
\text { KLOSE }\end{array}$ & LAZIO & 12 & 7 & 3 & 7 & 1442 \\
\hline 8 & $\begin{array}{l}\text { A. } \\
\text { MORATA }\end{array}$ & JUVENTUS & 22 & 7 & 6 & 7 & 1554 \\
\hline 9 & $\begin{array}{l}\text { MOHAMED } \\
\text { SALAH }\end{array}$ & ROMA & 8 & 6 & 3 & 13 & 2838 \\
\hline 10 & $\begin{array}{l}\text { EDIN } \\
\text { DZEKO }\end{array}$ & ROMA & 8 & 6 & 6 & 8 & 2070 \\
\hline
\end{tabular}


Table 17:Top Ten Forwards based on Warning cards

\begin{tabular}{|c|c|c|c|c|c|c|c|}
\hline \multicolumn{2}{|r|}{ Player } & Team & $\begin{array}{c}\text { Over } \\
\text { all } \\
\text { clean } \\
\text { sheet }\end{array}$ & $\begin{array}{c}\text { Over } \\
\text { all } \\
\text { assist }\end{array}$ & $\begin{array}{c}\text { Over } \\
\text { all } \\
\text { cards }\end{array}$ & $\begin{array}{c}\text { Over } \\
\text { all } \\
\text { Goal }\end{array}$ & $\begin{array}{c}\text { Over } \\
\text { all } \\
\text { time }\end{array}$ \\
\hline 1 & $\begin{array}{l}\text { FEDERICO } \\
\text { DIONISI }\end{array}$ & FROSINONE & 7 & 4 & 12 & 9 & 2580 \\
\hline 2 & $\begin{array}{l}\text { DOMENICO } \\
\text { BERARDI }\end{array}$ & SASSUOLO & 11 & 6 & 11 & 7 & 2257 \\
\hline 3 & $\begin{array}{l}\text { RICCARDO } \\
\text { MEGGIORINI }\end{array}$ & CHIEVO & 12 & 7 & 10 & 5 & 1712 \\
\hline 4 & $\begin{array}{l}10 \text { RIGHT } \\
\text { MATT }\end{array}$ & BOLOGNA & 13 & 3 & 9 & 8 & 2257 \\
\hline 5 & $\begin{array}{l}\text { MAURICIO } \\
\text { PINILLA }\end{array}$ & ATALANTA & 11 & 2 & 9 & 5 & 1412 \\
\hline 6 & $\begin{array}{l}\text { NICOLA } \\
\text { SANSONE }\end{array}$ & SASSUOLO & 11 & 4 & 8 & 7 & 2520 \\
\hline 7 & $\begin{array}{l}\text { SIMONE } \\
\text { ZAZA }\end{array}$ & JUVENTUS & 22 & 0 & 8 & 5 & 721 \\
\hline 8 & $\begin{array}{l}14 \text { DRIES } \\
\text { MERTENS }\end{array}$ & NAPLES & 15 & 5 & 7 & 5 & 1192 \\
\hline 9 & $\begin{array}{l}\text { MARKO } \\
\text { LIVAJA }\end{array}$ & EMPOLI & 12 & 0 & 7 & 1 & 672 \\
\hline 10 & EDIN DZEKO & ROME & 8 & 6 & 6 & 8 & 2070 \\
\hline & & & & & & & \\
\hline
\end{tabular}

\subsubsection{Visualization}

\subsubsection{Parallel Coordinates}

In order to have a better understanding of how the players performed, a parallel coordinates plot was constructed.

The lines represent all the players for a particular position. The colour scheme we have implemented is to bring attention to players with notable 
characteristics. For instance, if a player is coloured differently than yellow it indicates that the player achieved either the highest or lowest value of a certain variable. If two or more players tie for the highest (lowest) value for a particular variable, they are colour-coded the same.

To better understand this graph (since other graphs are too busy) an example with 10 players is presented below.

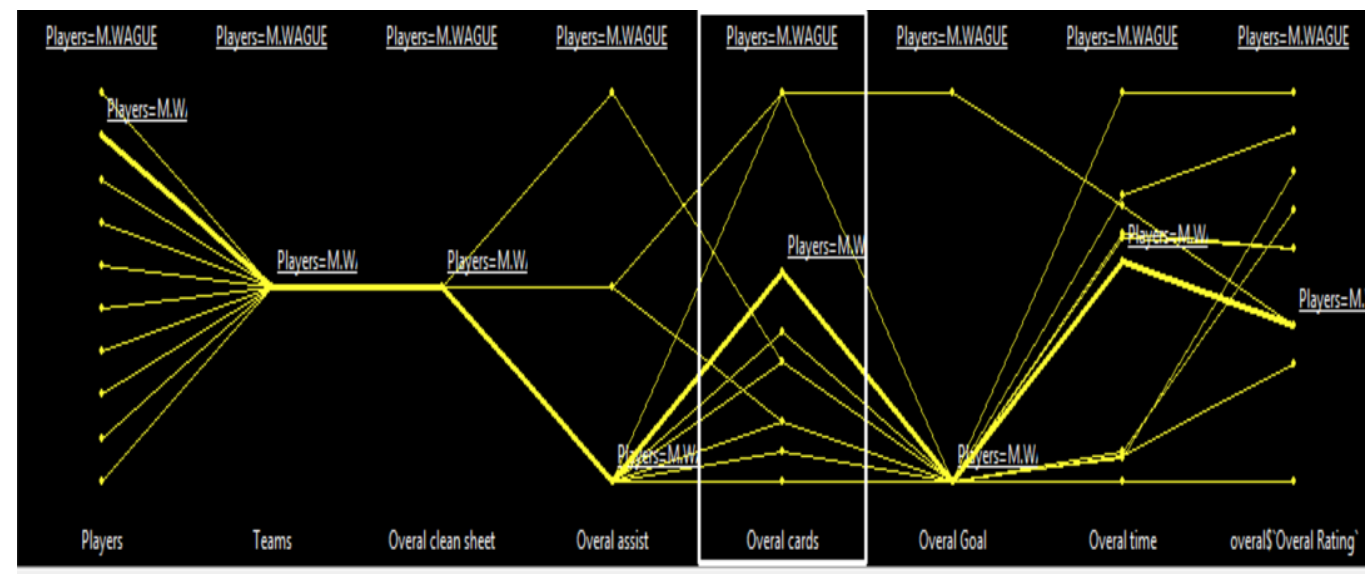

Figure 4: Parallel Coordinates example

Ggobi is an interactive tool within $\mathrm{R}$ that can be used to better understand Ggobi we can hover over a point and identify the player associated with that reading. In the parallel coordinates plot above, the defender M. Wague is highlighted in yellow and we can follow his performance on different attributes. For instance, he has the second highest number of warning cards 
amongst all the defenders, he did not score any goals that season and also, he is ranked fourth among his team mates in overall time played on the field. This graph will be used later in the association rule mining section. 


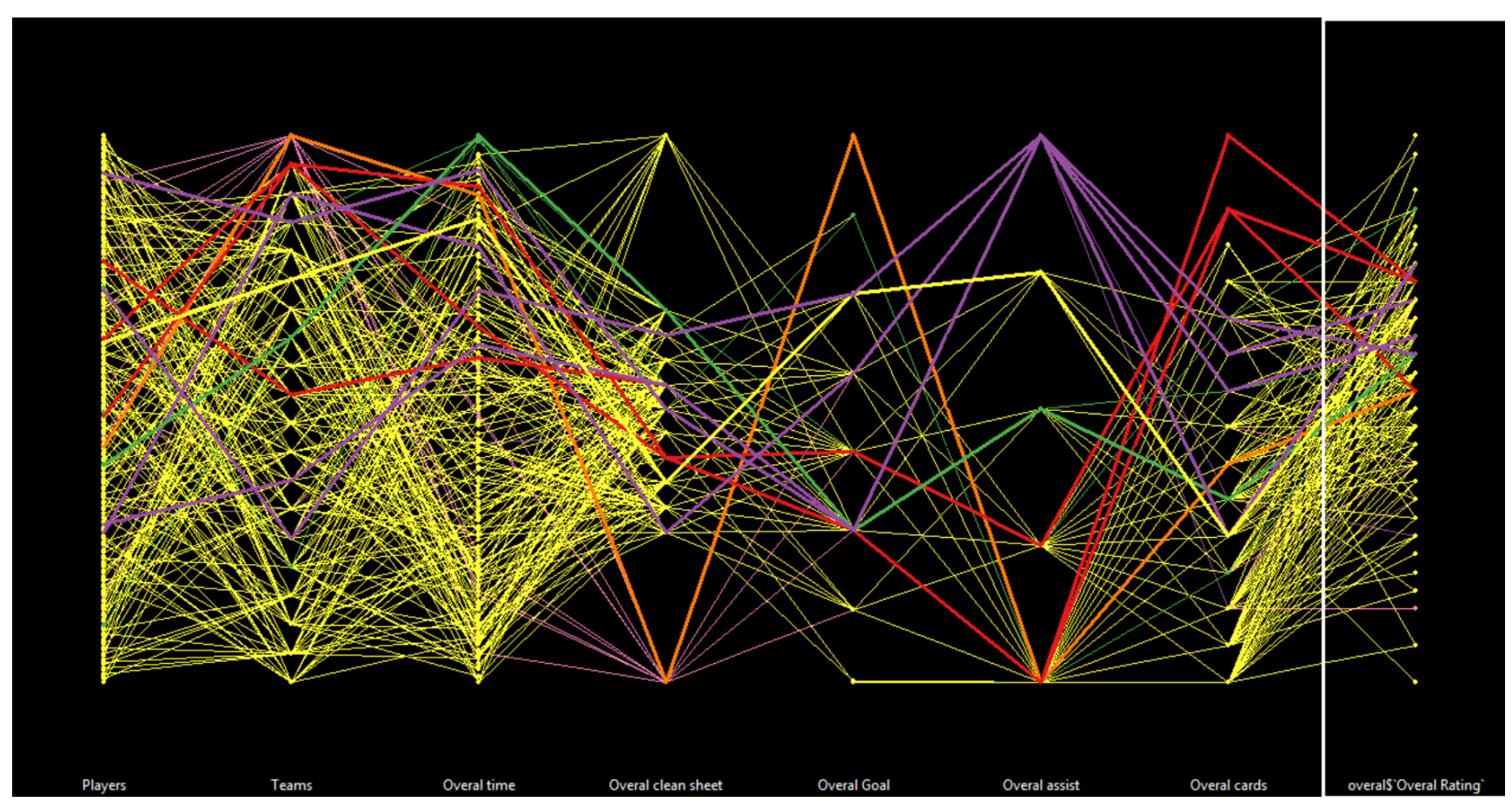

Figure 5: Parallel Coordinates for Defenders 
Midfielders

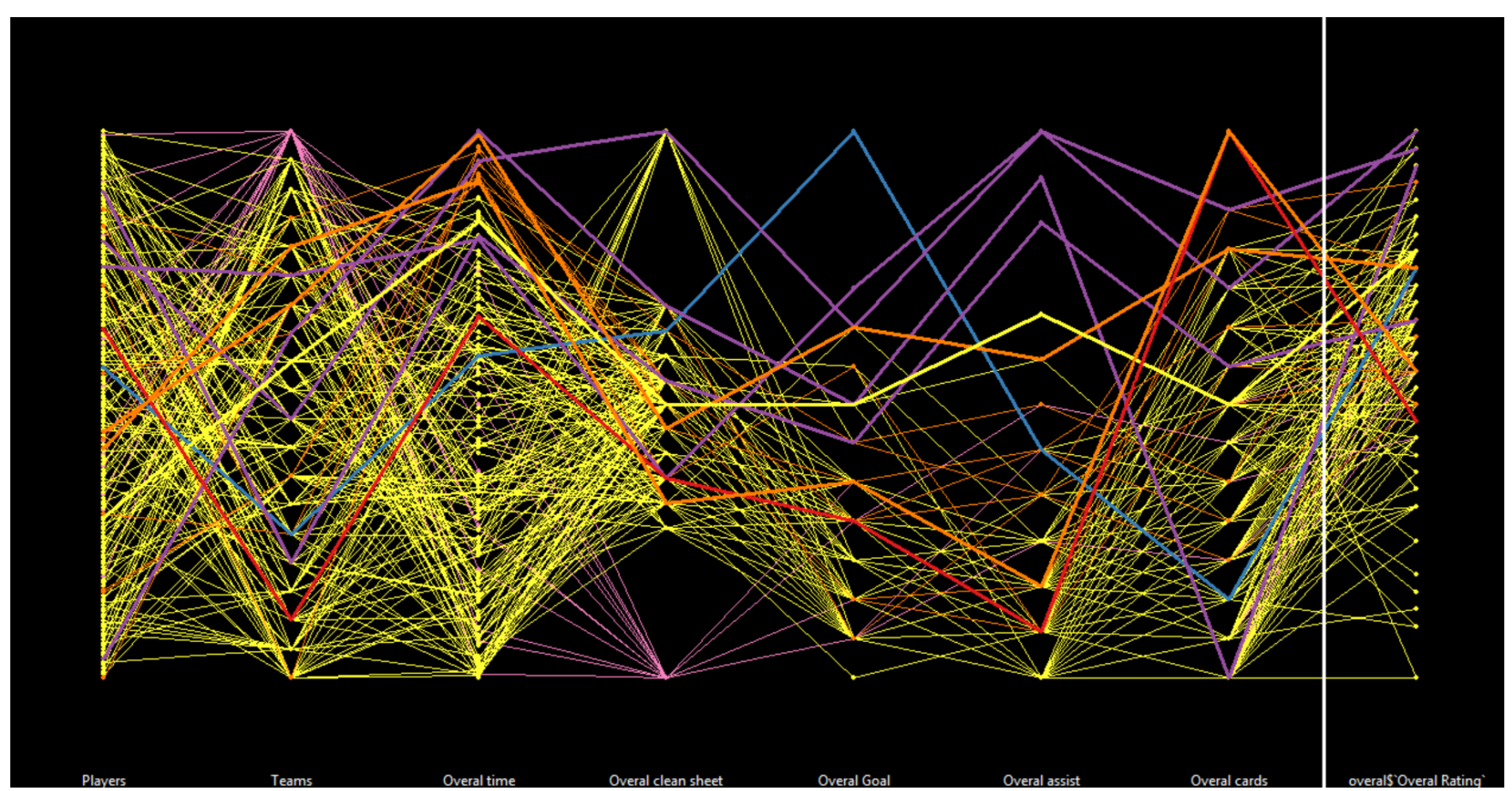

Figure 6: Parallel Coordinates for Midfielders 


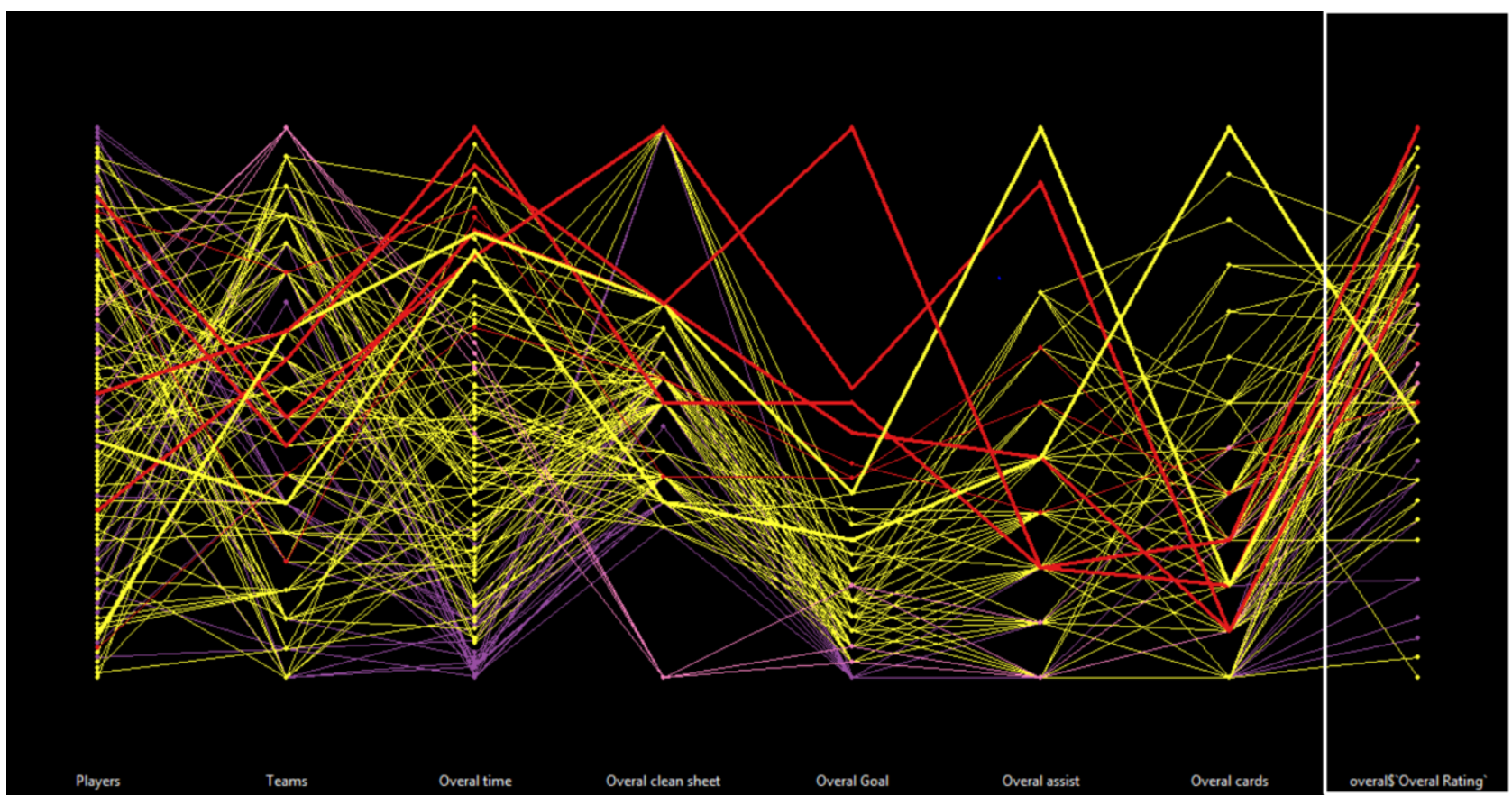

Figure 7: Parallel Coordinates for Strikers 


\subsubsection{Findings Based on the Parallel Coordinates Plots}

With parallel coordinates, we can examine players based on their performance. Recall, if a striker gets a lot of warning cards, it can be troublesome for the team at some point during the season because five (5) yellow cards in different matches or a red card or (2 yellow cards) in a match will result in the player being banned for the next game, resulting in the team being unable to play that player in the next game. Another reason that a striker receives warning cards may be due to the style of game play and tactics used by a team. Usually this type of game play and style requires a striker who is always pressuring the opponent's defenders, thereby causing them to make mistakes.

Another use of parallel coordinates is to examine the overall performance of the players, variable by variable.

From Figures 4-6, it is obvious that, among all 20 teams in the league, only one team had no clean sheets - the team (Frosinone) with the silver color legend. Note that their strikers have not scored many goals - only nine (9) goals in total (Federico Dionisi). In the entire season the team scored only 35 goals, compared to Roma which was the highest scoring team with 83 goals.

Later in the research parallel coordinates will be used to show the performance of a player compared to his teammates. 
4. Methodologies

In this chapter, we outline the methodologies proposed to address our research questions.

\subsection{Scoring/Ranking Players}

The first question was: Can we duplicate the EA Sports' FIFA 2015-16 players' scorings/rankings (since we did not have access to the formulae or the complete data set implemented within the system)?

The two methods we propose are Neural Networks Regression and Ordinal Logistic Regression.

\subsubsection{Neural Network Regression}

A multiple regression model is a linear combination of $p-1$ predictors such that

$$
E\left\{Y_{i}\right\}=\beta_{0}+\beta_{1} X_{i 1}+\cdots+\beta_{p-1} X_{i, p-1} .
$$

A Neural Networks regression model is used to model the response variable as a nonlinear function of various linear combinations of the predictor variables. It is a nonlinear statistical model that contains many more parameters than a linear statistical model. One of the major shortcomings of neural networks regression modelling is that it will usually be over-parameterized - there are parameters that are uninterpretable. On the other hand, neural network regression models often perform better in predicting future responses than regression models. 
The simplest but at the same time the most widely-used neural network model, the single-hidden-layer, feedforward neural network, is described below. This model is also referred to as a single-layer perceptron. In this neural networks model, there is one hidden layer with $m$ nodes in the hidden layer and the $i$ th response $Y_{i}=1, \ldots, n$, is modeled as a nonlinear function $g_{Y}$ of $m$ derived predictor values $H_{i 0}, H_{i 1}, \ldots, H_{i, m-1}$ :

$$
Y_{i}=g_{Y}\left(\beta_{0} H_{i 0}+\beta_{1} H_{i 1}++\beta_{i, m-1} H_{i, m-1}\right)=g_{Y}\left(\boldsymbol{H}_{\boldsymbol{i}}^{\prime} \boldsymbol{\beta}\right)
$$

where

$$
\boldsymbol{\beta}_{m \times 1}=\left[\begin{array}{c}
\beta_{0} \\
\beta_{1} \\
\vdots \\
\beta_{m-1}
\end{array}\right] \text { and } \quad \boldsymbol{H}_{i_{m \times 1}}=\left[\begin{array}{c}
H_{i 0} \\
H_{i 1} \\
\vdots \\
H_{i, m-1}
\end{array}\right] \text { and } H_{i 0}=1
$$

The $\mathrm{j}^{\text {th }}$ predictor value $H_{i j}, j=1, \ldots, m-1$ for the $i^{\text {th }}$ observation is a nonlinear function $g_{j}$ of a linear combination of the original $p-1$ input predictor variables and the bias term, i.e.,

$$
H_{i j}=g_{j}\left(\boldsymbol{X}_{i}^{\prime} \boldsymbol{\alpha}_{j}\right) \quad j=, \ldots, m-1
$$

where:

$$
\boldsymbol{\alpha}_{j_{p \times 1}}=\left[\begin{array}{c}
\alpha_{j 0} \\
\alpha_{j 1} \\
\vdots \\
\alpha_{j, p-1}
\end{array}\right] \text { and } \boldsymbol{X}_{i_{p \times 1}}=\left[\begin{array}{c}
X_{i 0} \\
X_{i 1} \\
\vdots \\
X_{i, p-1}
\end{array}\right]
$$

and $X_{i 0}=1$. Note that $\boldsymbol{X}_{\boldsymbol{i}}^{\prime}$ is the $\mathrm{i}^{\text {th }}$ row of the $\boldsymbol{X}$ input matrix of predictor variables. Equations 1 and 3 together form the neural network model: 


$$
Y_{i}=g_{Y}\left(\boldsymbol{H}_{i}^{\prime} \boldsymbol{\beta}\right)=g_{Y}\left[\beta_{0}+\sum_{j=1}^{m-1} \beta_{j} g_{i}\left(\boldsymbol{X}_{i}^{\prime} \boldsymbol{\alpha}_{j}\right)\right]
$$

The functions $g_{Y}, g_{1}, \ldots, g_{m-1}$ are called activation functions in the neural networks literature. To completely specify the neural network model, it is necessary to identify the $m$ activation functions. A common choice for each of these functions is the logistic function:

$$
g(Z)=1 /\left(1+e^{-Z}\right)=\left[1+e^{-Z}\right]^{-1}
$$

This function is flexible and can be adapted to a variety of circumstances.

Use of n (5) for each of $g_{Y}, g_{1}, \ldots, g_{m-1}$ in (4) yields the specific neural network model to be discussed in this section:

$$
\begin{aligned}
Y_{i} & =\left[1+\exp \left(-\boldsymbol{H}_{i}^{\prime} \boldsymbol{\beta}\right)\right]^{-1} \\
& =f\left(\boldsymbol{X}_{i}, \alpha_{1}, \ldots, \alpha_{m-1}, \boldsymbol{\beta}\right)
\end{aligned}
$$

where $\beta, \alpha_{1}, \ldots, \alpha_{m-1}$ are unknown parameter vectors, $\boldsymbol{X}_{i}$ is a vector of known constants.

Neural networks model $f\left(\boldsymbol{X}_{i}, \alpha_{1}, \ldots, \alpha_{m-1}, \beta\right)$ is a special case of a nonlinear regression model. Recall, however, that these models are generally over-parameterized and use of standard estimation methods will result in fitted models that generally have poor 
predictive ability. This is analogous to leaving too many unimportant predictors in a linear regression model.

Note that because the logistic activation function is bounded between 0 and 1 , it is necessary to scale $Y_{i}$ so that the scaled value $Y_{i}^{s c}$ also falls within these limits. This can be accomplished by using:

$$
\frac{Y_{i}-Y_{\min }}{Y_{\max }-Y_{\min }}
$$

where $Y_{\min }$ and $Y_{\max }$ are the minimum and maximum values, respectively, of the response variable. It is also common practice to center and scale each of the predictors to have mean 0 and standard deviation 1 . In our work, the response variable is overall player performance rankings from EA Sports' FIFA 2015-16 season. The predictor variables used are, for each player, playing time, goals scored, assists, and warning cards.

The reason that Neural Network (NNET was chosen, is that this machine learning model has not been examined for use in this context before and also NNET addresses the non-linearity of the problem. Moreover, NNET does not have assumptions and it can be used for almost any type of modeling.

There are other choices for activation functions $g$ for NNET such as: Rectified linear unit (ReLU), Exponential linear unit (ELU) and Tanh. As mentioned before, we used a logistic activation function since it can capture the non-linearity of the relationship between response and predictor variables. 


\subsubsection{Ordinal Logistic Regression}

\subsubsection{Multiple Logistic Regression Model}

Following Kutner et al in [19], when the response variable is binary, we consider that the response variables $Y_{i}$ are independent Bernoulli random variables with expected values $E\left\{Y_{i}\right\}=\pi_{i}$ where $\pi_{i}$ represents the probability of $Y_{i}=1$. Then

$$
E\left\{Y_{i}\right\}=\pi_{i}=\frac{\exp \left(\beta_{0}+\beta_{1} X_{i}\right)}{1+\exp \left(\beta_{0}+\beta_{1} X_{i}\right)}
$$

It is simple to extend the equation above to more than one predictor variable. In extending the simple logistic regression model, we simply replace $\beta_{0}+\beta_{1} X_{i}$ by $\beta_{0}+$ $\beta_{1} X_{i}+\cdots+\beta_{p-1} X_{p-1}$. To simplify the formulae, we use matrix notation:

$$
\boldsymbol{\beta}_{p \times 1}=\left[\begin{array}{c}
\beta_{0} \\
\beta_{1} \\
\vdots \\
\beta_{p-1}
\end{array}\right], \quad \boldsymbol{X}_{n x p}=\left[\begin{array}{c}
\boldsymbol{X}_{1} \\
\boldsymbol{X}_{2} \\
\vdots \\
\boldsymbol{X}_{n}
\end{array}\right], \quad \boldsymbol{X}_{i p \times 1}=\left[\begin{array}{c}
1 \\
X_{i 1} \\
X_{i 2} \\
\vdots \\
X_{i, p-1}
\end{array}\right], i=1, \ldots, n
$$

With this notation, the simple logistic response function extends to the multiple logistic response function as follows:

$$
E\left\{Y_{i}\right\}=\pi_{i}=\frac{\exp \left(\boldsymbol{X}_{\boldsymbol{i}}^{\prime} \boldsymbol{\beta}\right)}{1+\exp \left(\boldsymbol{X}_{\boldsymbol{i}}^{\prime} \boldsymbol{\beta}\right)}
$$


and

$$
E\{\boldsymbol{Y}\}=\boldsymbol{\pi}=\frac{\exp \left(\boldsymbol{X}^{\prime} \boldsymbol{\beta}\right)}{1+\exp \left(\boldsymbol{X}^{\prime} \boldsymbol{\beta}\right)}
$$

The logit transformation is:

$$
\pi^{\prime}=\log _{e}\left(\frac{\pi}{1-\pi}\right)
$$

and gives the logit response function in the form of a linear predictor:

$$
\boldsymbol{\pi}^{\prime}=\boldsymbol{X}^{\prime} \boldsymbol{\beta}
$$

The multiple logistic regression model can therefore be stated as follows:

$Y_{i}$ are independent Bernoulli random variables with expected values $E\left\{Y_{i}\right\}=\pi_{i}$ where

$$
E\left\{Y_{i}\right\}=\pi_{i}=\frac{\exp \left(\boldsymbol{X}_{\boldsymbol{i}}^{\prime} \boldsymbol{\beta}\right)}{1+\exp \left(\boldsymbol{X}_{\boldsymbol{i}}^{\prime} \boldsymbol{\beta}\right)}
$$

where the observations $\mathrm{X}$ are considered to be known constants. Alternatively, if the X are random, $E\left\{Y_{i}\right\}$ is viewed as a conditional mean, given the values of $X_{i 1}, \ldots, X_{i, p-1}$.

Like the simple logistic response function, the multiple logistic response function is monotonic and sigmoidal in shape with respect to $\boldsymbol{X}^{\prime} \boldsymbol{\beta}$ and is almost linear when $\pi$ is between 0.2 and 0.8 . The $\boldsymbol{X}$ predictor variables may be quantitative or qualitative and represented by indicator variables. This flexibility makes the multiple logistic regression model very attractive. 


\subsubsection{Ordinal Logistic Regression}

Following Winship and de Mane [20] and Liu et al [21], an ordinal logistic regression model is a generalization of a binary logistic regression model when the outcome variable has more than two ordinal levels. It estimates the probability of being at or below a specific outcome level, conditional on a collection of explanatory variables.

The ordinal logistic model can be expressed as a latent variable model [22] [23]. Consider a set of observations $\mathrm{n}$ and vectors $X_{1}, X_{2}, \ldots, X_{p-1}$ that represent our predictor variables and responses $Y_{1}, Y_{2}, \ldots, Y_{k}$ where $Y_{i}$ is an ordinal variable $1, \ldots, k$. We fit a coefficient vector $\boldsymbol{\beta}$ of length $p$ and a set of thresholds $\theta_{1}, \ldots, \theta_{k}$ where $\theta_{1}<$ $\theta_{2}<\cdots<\theta_{k}$ is always true.

These thresholds divide the real number line into k disjoint segments, corresponding to the $\mathrm{k}$ responses [24]. Now the model becomes

$$
\operatorname{Pr}(Y \leq i \mid \boldsymbol{X})=\frac{1}{1+e^{-\left(\theta_{i}-\boldsymbol{\beta}^{\prime} \cdot \boldsymbol{X}\right)}} .
$$

Assuming the latent variable model $Y^{*}$ exists, it will be determined as

$$
Y^{*}=\boldsymbol{\beta}^{\prime} \boldsymbol{X}+\varepsilon
$$

where $\varepsilon$ is distributed $N(0,1)$ conditioned on X. The values of the observed ordinal variable $\mathrm{Y}$ fall within the regions divided by the cut points (thresholds). For example, $Y=0$ if $Y^{*} \leq \theta_{1}$. and 


$$
y=\left\{\begin{array}{cc}
1 & \text { if } y^{*} \leq \theta_{1} \\
2 & \text { if } \theta_{1}<y^{*} \leq \theta_{2} \\
3 & \text { if } \theta_{2}<y^{*} \leq \theta_{3} \\
\vdots & \vdots \\
k & \text { if } \theta_{k-1}<y^{*} \leq \theta_{k}
\end{array}\right\}
$$

We then find the conditional distribution of $Y$ as

$$
\begin{aligned}
& P(Y=k \mid \boldsymbol{X})=P\left(\theta_{k-1}<Y^{*} \leq \theta_{k} \mid \boldsymbol{X}\right) \\
& =P\left(\theta_{k-1}<\boldsymbol{\beta}^{\prime} \boldsymbol{X}+\varepsilon \leq \theta_{k}\right) \\
& =\Phi\left(\theta_{k}-\boldsymbol{\beta}^{\prime} \boldsymbol{X}\right)-\Phi\left(\theta_{k-1}-\boldsymbol{\beta}^{\prime} \boldsymbol{X}\right)
\end{aligned}
$$

where $\Phi$ is the cumulative distribution function of the standard normal distribution. The log-likelihood of the model for a single training example $\boldsymbol{x}_{i}, y_{i}$ can now be written as:

$$
\operatorname{loglikelihood}(\boldsymbol{\beta}, \boldsymbol{\theta} \mid \boldsymbol{x}, y)=\sum_{j=1}^{k}\left[y_{i}=j\right] \log \left[\Phi\left(\theta_{j}-\boldsymbol{\beta}^{\prime} \boldsymbol{X}\right)-\Phi\left(\theta_{j-1}-\boldsymbol{\beta}^{\prime} \boldsymbol{X}\right)\right]
$$

\subsubsection{Comparison of scoring and ranking methods}

To compare the two proposed scoring methods with the FIFA EASports scoring, we use repeated measures one-way ANOVA and, if we conclude there are differences, employ multiple comparison methods to assess the differences. To compare the three ranking methods, we use Spearman correlations and inter-rater reliability methods (IRR). 


\subsection{Methodology to address the second research question: Association}

\section{rule mining}

The second research question was: Is there a way to find if a player playing in a match increases the chance of winning for his particular team? Furthermore, can we find the combinations of players that are associated with a team winning (or losing)? In order to answer these questions, we employ association rule mining.

It is most often applied to binary-valued data $X_{j} \in\{0,1\}$, where it is referred to as "market basket" analysis. In that context the observations are sales transactions, such as those occurring at the checkout counter of a store. The variables represent all of the items sold in the store. For observation $i$, each variable $X_{j}$ is assigned one of two values; $x_{i j}=1$ if the $j^{\text {th }}$ item is purchased as part of the transaction, whereas $x_{i j}=0$ if it was not purchased. In any row, those variables that frequently have joint values of one represent items that are frequently purchased together. More generally, the basic goal of association rule analysis is to find a collection of prototypes $X$-values $v_{1}, \ldots, v_{L}$ for the feature vector $X$, such that the probability density $\operatorname{Pr}\left(v_{l}\right)$ evaluated at each of those values is relatively large. In this general framework the problem can be viewed as "mode finding" or "bump hunting." As formulated, this problem is impossibly difficult. A natural estimator for each $\operatorname{Pr}\left(v_{l}\right)$ is the fraction of observations for which $X=v_{l}$. For problems that involve more than a small number of values, the number of observations for which $X=v_{l}$ will nearly always be too small for reliable estimation. 
In order to have a tractable problem, both the goals of the analysis and the generality of the data to which it is applied must be greatly simplified.

An association rule is a rule such that "If a customer buys Item A and Item B, they often buy C as well"

$$
\text { i.e. } A \text { and } B \Rightarrow C
$$

\subsubsection{The Apriorl Algorithm}

The Apriori algorithm uses three key components to determine how a rule is a good rule. These components are: support, confidence and lift. The idea is to only look at the highly probable sets and combine them; otherwise, since the number of items are high, it makes it impossible to inspect all combinations of items. The Apriori algorithm uses the fact that if an itemset is infrequent, then all the combinations of that itemset with other itemsets must also be infrequent.

Below are definitions of support, confidence and lift that are used to examine rules that are found.

The first key component is support:

$$
\text { Support }(A, B, C)=\left(\frac{\text { Number of items contating } A, B \text { and } C}{\text { Total number of baskets }}\right) \times 100 \%
$$




$$
=P(A \cap B \cap C)
$$

Only those sets exceeding a specified level of support are considered as candidates for further analysis. This will reduce the number of rules and combinations.

The second key component is confidence:

$$
\begin{aligned}
\operatorname{Confidence}(\text { rule }) & =\left(\frac{\operatorname{Support}(A, B, C)}{\operatorname{Support}(A, B)}\right) \times 100 \% \\
& =P(C \mid A \cap B)
\end{aligned}
$$

By setting the confidence of a rule fairly high and restricting the rules to combinations of A and B only with sufficient support, still the desired results have to actually hold high confidence.

The last component is lift of a rule of the form $A$ and $B \Rightarrow C$ :

$$
\begin{gathered}
\operatorname{Lift}(\text { rule })=\left(\frac{\text { Confidence }(A, B, C)}{\text { Confidence }(A, B)}\right) \times 100 \% \\
=\frac{P(C \mid A \cap B)}{P(C)}
\end{gathered}
$$

In short, after restricting the results to things that occur often enough (support) and looking at how confident the rule would hold (confidence), interesting rules are the ones that really result in significant "improvement" (lift). 
If we go back to the research question, we are interested to find out which player or set of players is most associated with a t team winning (or losing) a match.

5. Results

\subsection{Scoring/Ranking Players Based on Performance during the 2015-16 Season}

The variables used in the analyses were:

- the number of clean sheets during the entire season

- the number of goals scored

- the number of assists

- the total time they spent on the pitch

- the number of warning cards

It is already known [25] that the more warning cards a player has, the greater the potential of having a negative effect on team performance, either as result of being 
banned from a game or even being sent off during the same match if the player gets two (2) yellow cards in the same match or one (1) red card, (which will also result in

being banned from the next match). In some cases, based on the intensity of the foul, a player can even get banned for a few matches.

We used two methods to score (and subsequently rank) players. We compared the results with a reference method - the best available was for FIFA from EASports, which is a football video game [26]. We tested to determine if either or both of these methods could duplicate the FIFA EASports scoring.

\subsubsection{Preparation of the Data for Scoring and Ranking}

First, we needed to remove players for whom there was no record in EASports, since they were not ranked by FIFA [26]. Goalkeepers are not included in our analysis so they were removed as well from the dataset. This reduced the number of players to 544. We also noted that there were players for whom there were no readings for the variables. Removing them reduced the dataset to 489 players. These 489 players all played at least one minute during the season and their EASports FIFA ranking existed. In the following we discuss how our scoring models were built.

\subsubsection{Predictor Variables}

We began by examining relationships among the predictor variables. Including variables that are highly correlated with each other may result in unstable models due 
to multicollinearity. The Performance Analytics package in R [27] was used to obtain Figure 20, the chart of the correlation matrix for the variables. From this visualization, we found the correlation between Overall Time and Total cards was 0.69 and between Overall goals and Overall assists was 0.55 . 


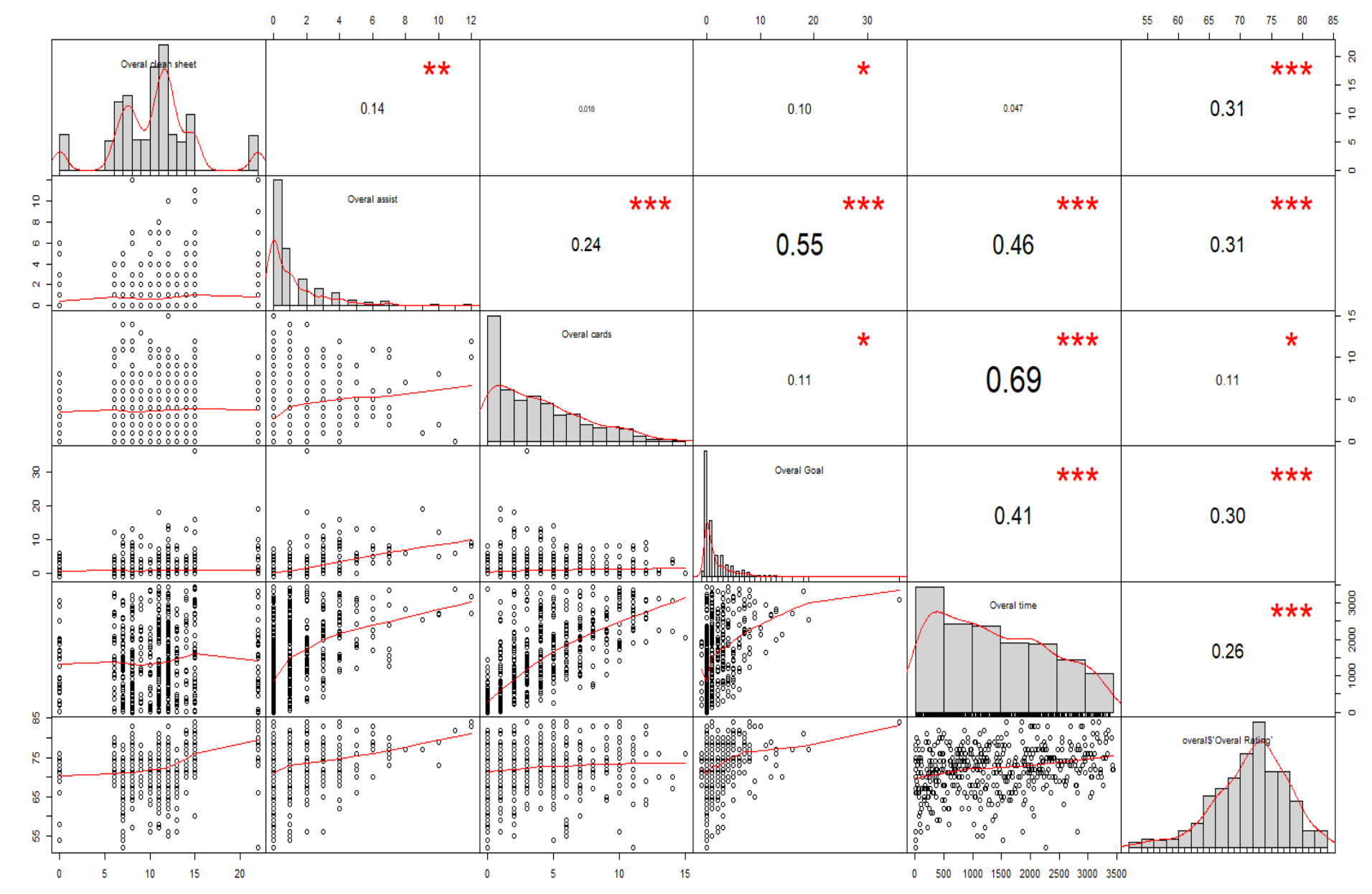

Figure 8:Chart of Correlation Matrix for predictor variables 


\subsubsection{Scoring Players: Using Neural Networks}

As mentioned before, the predictor variables for this model were:

- Overall time played during the season

- Total number of goals scored by the player

- Total number of warning cards received by the player (Combination of red cards and yellow cards. Each red card was treated as equivalent to two yellow cards)

- Total Clean sheets for the entire season

- Total number of assists by the player for the entire season

- Indicator of position played. Two indicator variables were used in order to define position- the first was the defender indicator; the second was the midfield indicator. If both were zero the player was a striker.

\subsubsection{Building the Model}

The first attempt to build the model used a Neural Network with a single hidden layer with two nodes in the hidden layer and did not define any starting weights in the code, hence the starting weights were randomly chosen. 
The results were as follows:

Sum Square of Errors (Model 1) $=10974.57$

Summary Statistics from fitted predictions:

Table 18:The summary of NNET Model1 with two hidden nodes and no initial assigned weights

\begin{tabular}{|ll|}
\hline Min & 73.83 \\
\hline 1st Quarter & 73.83 \\
\hline Median & 73.83 \\
\hline Mean & 73.83 \\
\hline 3rd Quarter & 73.83 \\
\hline Max & 73.83 \\
\hline
\end{tabular}

These results indicated that all of the predictions were 73.83; this did not seem reasonable and the sum of squares for error (SSE) was very high. The residuals plot below (Fig. 21) showed the poor fit of this initial model.

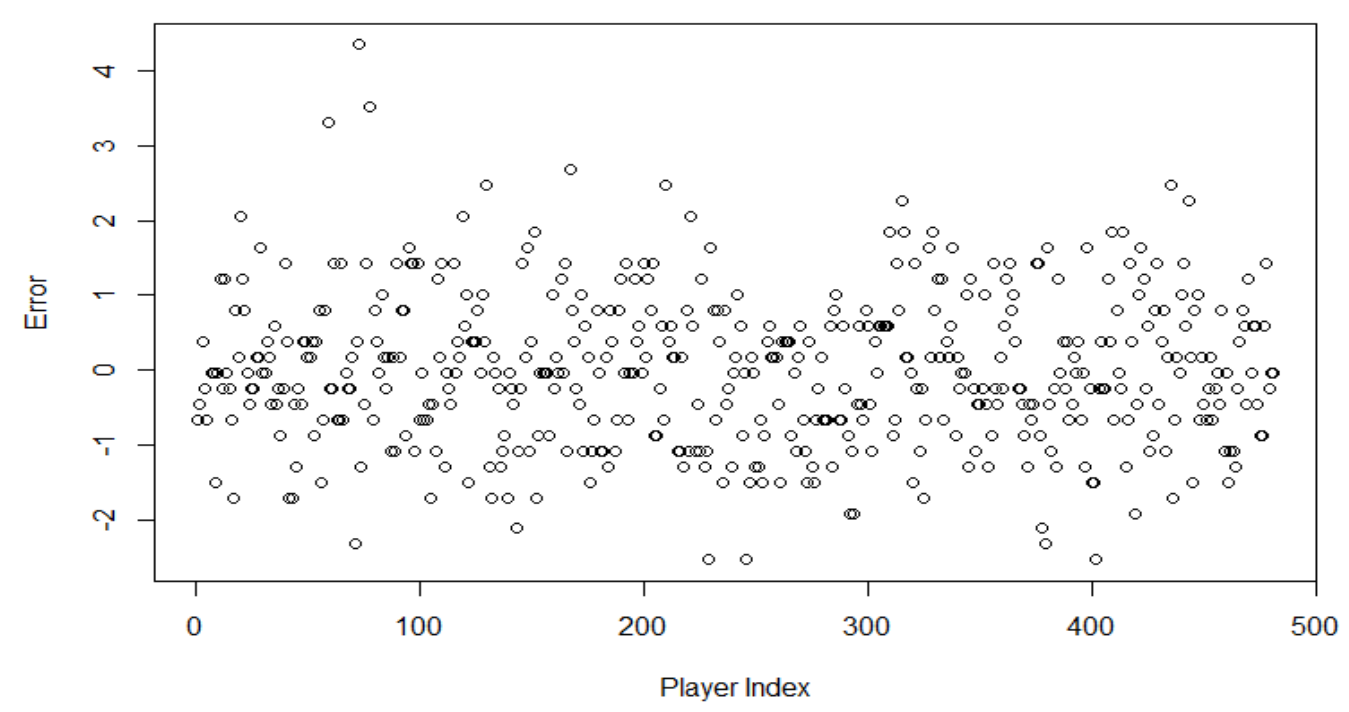

Figure 9: Residual Plot using 2 hidden Nodes with for NNet Model1 and random initial weights 
The second attempt used the final weights from this first model as a starting point and built a model again with two nodes in the hidden layer. The results were follows:

Table 19:The summary of NNET Model2 with two hidden nodes with starting weights from the NNET Model1

\begin{tabular}{|l|r|}
\hline Min & 73.83 \\
\hline 1st Quarter & 73.83 \\
\hline Median & 73.83 \\
\hline Mean & 73.83 \\
\hline 3rd Quarter & 73.83 \\
\hline Max & 73.83 \\
\hline
\end{tabular}

As shown in Table 19, the results were still not good This second model shows the same SSE for as Model 1(=10974.57). The corresponding plot of residuals (Fig. 9) demonstrated that there were many predictions that were far from the EASports' scorings.

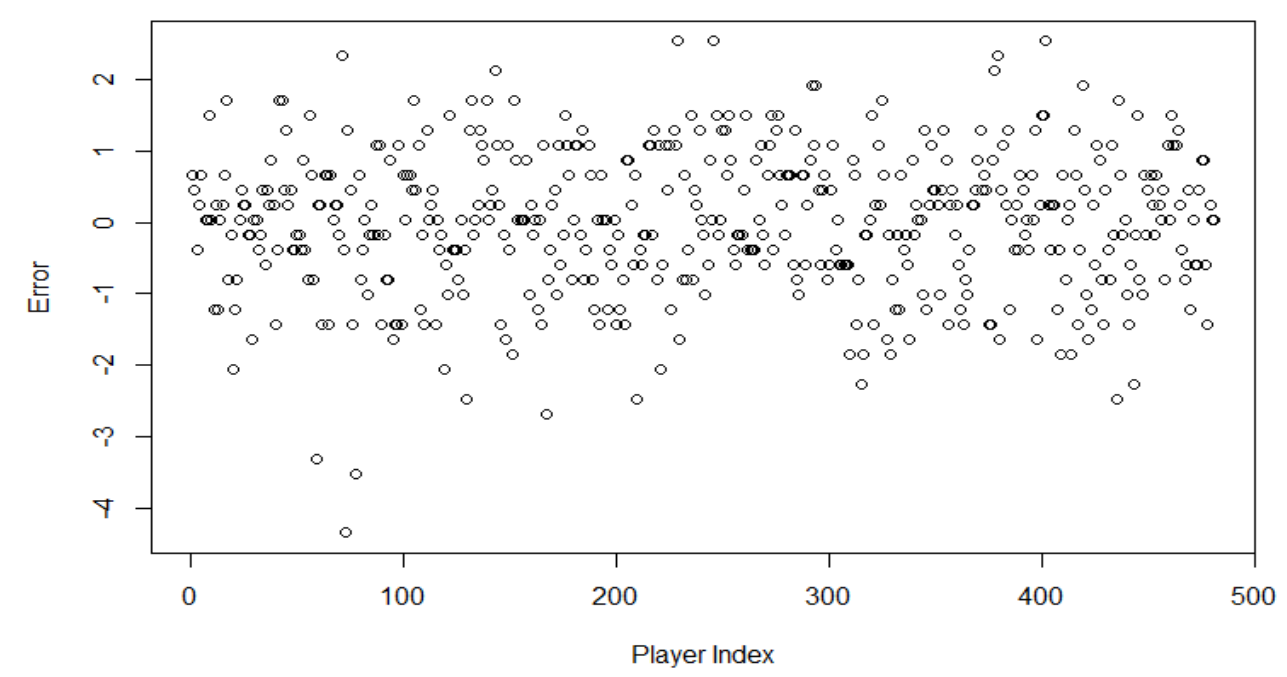

Figure 10: Residual Plot for NNET Model2 using 2 hidden nodes with initial weights from NNet Model1 
The next attempt added more nodes to the hidden layer. It consisted of ten (10)

hidden nodes, without predefining any starting weights. The results were as follows:

Table 20:The summary of NNET Model3 with ten nodes in hidden layer and no initial starting weights

\begin{tabular}{|lr|}
\hline Min & 58.99 \\
\hline 1st Quarter & 71.86 \\
\hline Median & 73.17 \\
\hline Mean & 73.83 \\
\hline 3rd Quarter & 75.41 \\
\hline Max & 83 \\
\hline
\end{tabular}

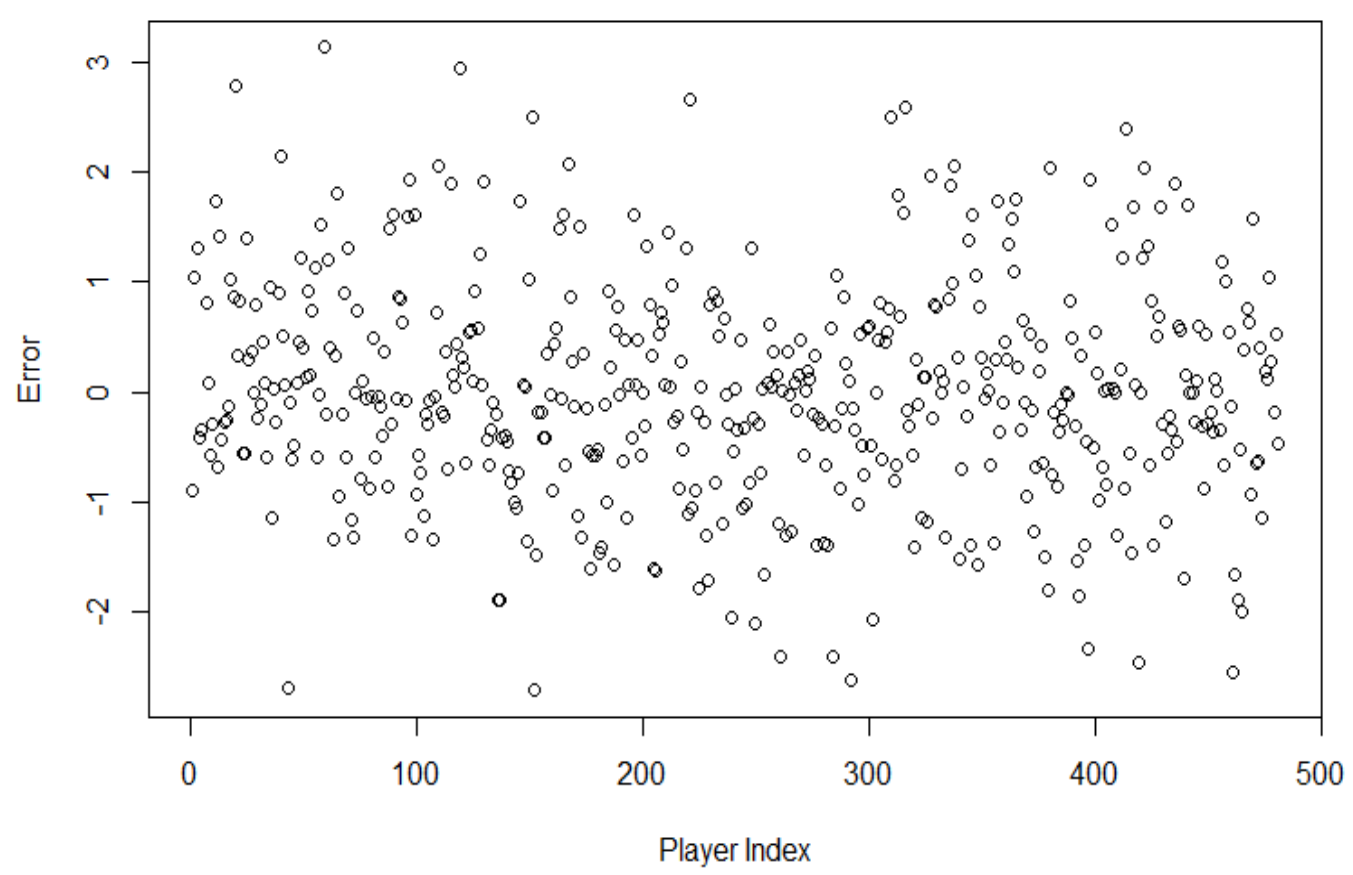

Figure 11:. Residual Pot for NNET Model3 with ten nodes in hidden layer and no initial starting weights 
In NNET Model3 we note that the distribution of errors appeared random and there were no obvious trends or systematic patterns in the plot. The SSE Model $3=4908.264$ has improved substantially.

Re-running the analysis but with starting weights obtained from the final weights of NNET Model3, we obtained NNET Model4. This model resulted in the same SSE ( $=4908.264)$ as Model3.

The result of the model is as follows:

Table 21:The summary of NNET Model4 with 10 nodes in the hidden layer and starting weights from NNET Model4

\begin{tabular}{|l|l|}
\hline Min & 52.94 \\
\hline 1st Quarter & 71.89 \\
\hline Median & 73.44 \\
\hline Mean & 73.83 \\
\hline 3rd Quarter & 75.55 \\
\hline Max & 86.69 \\
\hline
\end{tabular}

The residual plot in Figure 11 shows randomness with most readings around zero. 


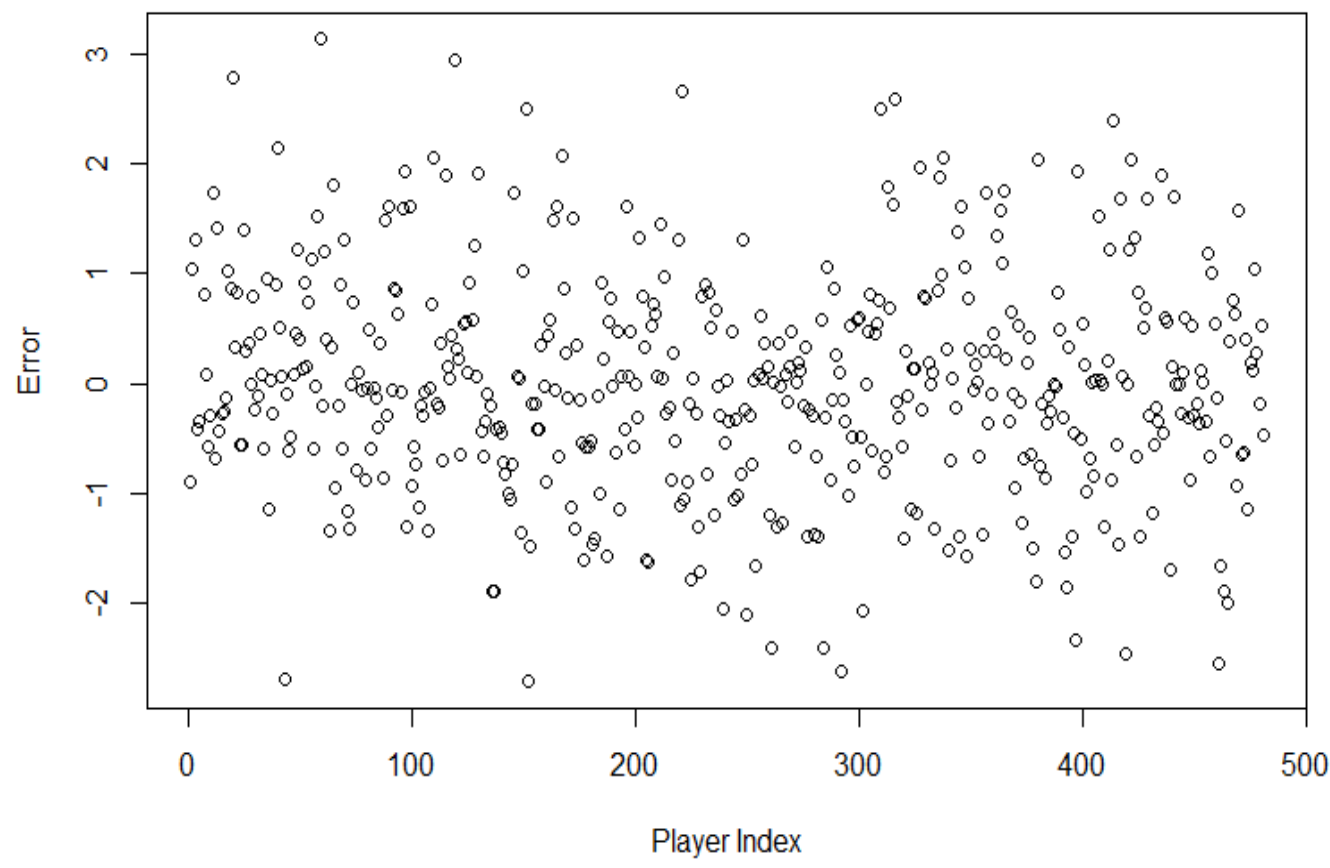

Figure 12: Residual Plot for NNET Model4

Using NNET Model4 we obtained the following table of predicted scores for the players:

Table 22:Players with EASports score and prediction from NNET Model4

\begin{tabular}{llcc|}
\hline Player & Team & $\begin{array}{c}\text { FIFA } \\
\text { Rating }\end{array}$ & $\begin{array}{c}\text { Predicted } \\
\text { Value }\end{array}$ \\
\hline GONZALO HIGUAIN & NAPOLI & 86 & 86.69 \\
\hline P. POGBA & JUVENTUS & 86 & 85.30 \\
\hline P. DYBALA & JUVENTUS & 81 & 84.26 \\
\hline L. BONUCCI & JUVENTUS & 83 & 83.40 \\
\hline MIRALEM PJANIC & ROMA & 84 & 82.92 \\
\hline M. MANDZUKIC & JUVENTUS & 82 & 82.61 \\
\hline A. MORATA & JUVENTUS & 80 & 82.46 \\
\hline MAURO ICARDI & INTER & 80 & 82.31 \\
\hline P. EVRA & JUVENTUS & 81 & 82.12 \\
\hline LORENZO INSIGNE & NAPOLI & 82 & 82.03 \\
\hline
\end{tabular}




\begin{tabular}{|c|c|c|c|}
\hline A. BARZAGLI & JUVENTUS & 85 & 81.95 \\
\hline JUAN CUADRADO & JUVENTUS & 81 & 81.90 \\
\hline CLAUDIO MARCHISIO & JUVENTUS & 84 & 81.26 \\
\hline ALEX SANDRO & JUVENTUS & 82 & 81.09 \\
\hline S. LICHTSTEINER & JUVENTUS & 82 & 81.04 \\
\hline MAREK HAMSIK & NAPOLI & 82 & 80.95 \\
\hline G. CHIELLINI & JUVENTUS & 86 & 80.89 \\
\hline SAMI KHEDIRA & JUVENTUS & 81 & 80.57 \\
\hline CARLOS BACCA & MILAN & 82 & 80.49 \\
\hline JOSE' CALLEJON & NAPOLI & 81 & 80.15 \\
\hline HERNANES & INTER & 80 & 79.98 \\
\hline SIMONE ZAZA & JUVENTUS & 79 & 79.93 \\
\hline RAUL ALBIOL & NAPOLI & 81 & 79.84 \\
\hline JOSIP ILICIC & FIORE & 80 & 79.78 \\
\hline EDER & SAMP & 79 & 79.65 \\
\hline JORGINHO & NAPOLI & 79 & 79.55 \\
\hline RICCARDO SAPONARA & EMPOLI & 78 & 79.48 \\
\hline MIRANDA & INTER & 85 & 79.43 \\
\hline ELSEID HYSAJ & NAPOLI & 77 & 79.37 \\
\hline I.PERISIC & INTER & 81 & 79.35 \\
\hline MIROSLAV KLOSE & LAZIO & 79 & 79.35 \\
\hline DANIELE RUGANI & JUVENTUS & 78 & 79.30 \\
\hline EL SHAARAWY & ROMA & 79 & 79.19 \\
\hline KALIDOU KOULIBALY & NAPOLI & 80 & 79.16 \\
\hline JEISON MURILLO & INTER & 79 & 79.16 \\
\hline MOHAMED SALAH & ROMA & 80 & 79.16 \\
\hline FRANCESCO ACERBI & SASSUOLO & 79 & 79.12 \\
\hline S. STURARO & JUVENTUS & 77 & 79.01 \\
\hline ADEM LJAJIC & ROMA & 79 & 78.99 \\
\hline HERNANES & JUVENTUS & 80 & 78.93 \\
\hline FAOUZI GHOULAM & NAPOLI & 78 & 78.66 \\
\hline ALLAN & NAPOLI & 80 & 78.61 \\
\hline BORJA VALERO & FIORE & 82 & 78.61 \\
\hline D.PEROTTI & ROMA & 79 & 78.52 \\
\hline GONZALO RODRIGUEZ & FIORE & 81 & 78.38 \\
\hline KWADWO ASAMOAH & JUVENTUS & 79 & 78.31 \\
\hline MASSIMO MACCARONE & EMPOLI & 75 & 78.26 \\
\hline ALEJANDRO GOMEZ & ATALANTA & 78 & 78.21 \\
\hline
\end{tabular}




\begin{tabular}{|c|c|c|c|}
\hline MARIO LEMINA & JUVENTUS & 76 & 78.19 \\
\hline FEDERICO BERNARDESCHI & FIORE & 77 & 78.17 \\
\hline BONAVENTURA & MILAN & 80 & 78.17 \\
\hline MARCELO BROZOVIC & INTER & 78 & 78.10 \\
\hline VICTOR IBARBO & ROMA & 78 & 78.06 \\
\hline KINGSLEY COMAN & JUVENTUS & 78 & 78.01 \\
\hline VALTER BIRSA & CHIEVO & 75 & 78.01 \\
\hline ADAM MASINA & BOLOGNA & 73 & 78.00 \\
\hline MARCOS ALONSO & FIORE & 75 & 78.00 \\
\hline VICTOR IBARBO & ROMA & 78 & 77.96 \\
\hline FERNANDO LLORENTE & JUVENTUS & 80 & 77.94 \\
\hline R. PEREYRA & JUVENTUS & 80 & 77.91 \\
\hline MARIO RUI & EMPOLI & 76 & 77.85 \\
\hline FRANCO VAZQUEZ & PALERMO & 80 & 77.84 \\
\hline EDIN DZEKO & ROMA & 80 & 77.74 \\
\hline RICCARDO MEGGIORINI & CHIEVO & 75 & 77.72 \\
\hline MARTIN CACERES & JUVENTUS & 80 & 77.69 \\
\hline DAVIDE ASTORI & FIORE & 79 & 77.67 \\
\hline SIMONE PADOIN & JUVENTUS & 74 & 77.64 \\
\hline GARY MEDEL & INTER & 81 & 77.62 \\
\hline MATTIA DESTRO & BOLOGNA & 76 & 77.60 \\
\hline SIME VRSALJKO & SASSUOLO & 77 & 77.60 \\
\hline DOMENICO BERARDI & SASSUOLO & 81 & 77.56 \\
\hline LUCA ANTONELLI & MILAN & 77 & 77.54 \\
\hline DRIES MERTENS & NAPOLI & 81 & 77.54 \\
\hline TOMAS RINCON & GENOA & 75 & 77.54 \\
\hline FACUNDO RONCAGLIA & FIORE & 75 & 77.53 \\
\hline MANUEL PUCCIARELLI & EMPOLI & 73 & 77.49 \\
\hline GERVINHO & ROMA & 80 & 77.40 \\
\hline MAURICIO ISLA & JUVENTUS & 75 & 77.30 \\
\hline RODRIGO PALACIO & INTER & 79 & 77.23 \\
\hline LEONARDO PAVOLETTI & GENOA & 75 & 77.22 \\
\hline PIOTR ZIELINSKI & EMPOLI & 74 & 77.16 \\
\hline FEDERICO PELUSO & SASSUOLO & 73 & 77.11 \\
\hline ANDREA BELOTTI & TORINO & 75 & 77.10 \\
\hline LUIS MURIEL & SAMP & 75 & 77.04 \\
\hline ALBERTO PALOSCHI & CHIEVO & 77 & 77.00 \\
\hline CYRIL THEREAU & UDINESE & 77 & 77.00 \\
\hline
\end{tabular}




\begin{tabular}{|c|c|c|c|}
\hline BOSTJAN CESAR & CHIEVO & 77 & 76.92 \\
\hline NICOLA SANSONE & SASSUOLO & 77 & 76.89 \\
\hline ARMANDO IZZO & GENOA & 74 & 76.89 \\
\hline DANIEL CIOFANI & FROSINONE & 72 & 76.82 \\
\hline DUSAN BASTA & LAZIO & 79 & 76.81 \\
\hline STEVAN JOVETIC & INTER & 80 & 76.78 \\
\hline MATIAS VECINO & FIORE & 75 & 76.77 \\
\hline MARTEN DE ROON & ATALANTA & 76 & 76.75 \\
\hline DIEGO LAXALT & GENOA & 73 & 76.69 \\
\hline BOUKARY DRAME' & ATALANTA & 74 & 76.68 \\
\hline MASSIMO GOBBI & CHIEVO & 73 & 76.66 \\
\hline DANIELE GASTALDELLO & BOLOGNA & 76 & 76.62 \\
\hline ANTONIO CANDREVA & LAZIO & 81 & 76.61 \\
\hline FELIPE MELO & INTER & 79 & 76.60 \\
\hline LUCA ROSSETTINI & BOLOGNA & 74 & 76.57 \\
\hline ALESSIO ROMAGNOLI & MILAN & 76 & 76.54 \\
\hline YUTO NAGATOMO & INTER & 74 & 76.49 \\
\hline FELIPE ANDERSON & LAZIO & 79 & 76.46 \\
\hline GEOFFREY KONDOGBIA & INTER & 76 & 76.46 \\
\hline MILAN BADELJ & FIORE & 78 & 76.39 \\
\hline FRANCESCO TOTTI & ROMA & 79 & 76.39 \\
\hline SENAD LULIC & LAZIO & 77 & 76.33 \\
\hline P.KONE & FIORE & 75 & 76.31 \\
\hline MANOLO GABBIADINI & NAPOLI & 78 & 76.31 \\
\hline M'BAYE NIANG & MILAN & 75 & 76.26 \\
\hline ALEX TELLES & INTER & 76 & 76.22 \\
\hline A.IONITA & Verona & 74 & 76.20 \\
\hline LUCAS CASTRO & CHIEVO & 75 & 76.16 \\
\hline LUCAS BIGLIA & LAZIO & 81 & 76.11 \\
\hline MAURICIO & LAZIO & 78 & 76.11 \\
\hline FABRIZIO CACCIATORE & CHIEVO & 72 & 76.09 \\
\hline LEANDRO PAREDES & EMPOLI & 74 & 76.04 \\
\hline FRANCESCO MAGNANELLI & SASSUOLO & 76 & 76.01 \\
\hline DANILO D'AMBROSIO & INTER & 74 & 75.99 \\
\hline LORENZO TONELLI & EMPOLI & 78 & 75.97 \\
\hline A. RUDIGER & ROMA & 76 & 75.93 \\
\hline PAOLO CANNAVARO & SASSUOLO & 75 & 75.88 \\
\hline NICOLAS BURDISSO & GENOA & 76 & 75.82 \\
\hline
\end{tabular}




\begin{tabular}{|c|c|c|c|}
\hline C.TELLO & FIORE & 78 & 75.81 \\
\hline EMILIANO MORETTI & TORINO & 77 & 75.80 \\
\hline OSCAR HILEMARK & PALERMO & 72 & 75.77 \\
\hline MARCO PAROLO & LAZIO & 80 & 75.71 \\
\hline GREGOIRE DEFREL & SASSUOLO & 73 & 75.68 \\
\hline ADAM LAJIC & INTER & 79 & 75.66 \\
\hline LARANGEIRA DANILO & UDINESE & 76 & 75.66 \\
\hline SEBASTIAN DE MAIO & GENOA & 76 & 75.64 \\
\hline MARCO BORRIELLO & CARPI & 74 & 75.62 \\
\hline FABIO QUAGLIARELLA & TORINO & 78 & 75.60 \\
\hline KEITA & LAZIO & 77 & 75.50 \\
\hline CRISTIAN ANSALDI & GENOA & 79 & 75.49 \\
\hline FEDERICO DIONISI & FROSINONE & 72 & 75.46 \\
\hline NENAD TOMOVIC' & FIORE & 75 & 75.42 \\
\hline LUCA TONI & Verona & 74 & 75.41 \\
\hline EMANUELE GIACCHERINI & BOLOGNA & 77 & 75.38 \\
\hline ALFRED DUNCAN & SASSUOLO & 73 & 75.32 \\
\hline MARIOS OIKONOMOU & BOLOGNA & 75 & 75.23 \\
\hline ANTHONY MOUNIER & BOLOGNA & 76 & 75.19 \\
\hline ROBERTO SORIANO & SAMP & 76 & 75.14 \\
\hline SIMONE PEPE & CHIEVO & 76 & 75.14 \\
\hline M.BISEVAC & LAZIO & 77 & 75.13 \\
\hline JURAJ KUCKA & MILAN & 77 & 75.04 \\
\hline SAPHIR TAIDER & BOLOGNA & 73 & 74.96 \\
\hline ANTONIO DI NATALE & UDINESE & 77 & 74.94 \\
\hline C.IMOOBILE & TORINO & 79 & 74.93 \\
\hline SANTIAGO GENTILETTI & LAZIO & 77 & 74.91 \\
\hline WESLEY HOEDT & LAZIO & 75 & 74.90 \\
\hline ANDREA MASIELLO & ATALANTA & 73 & 74.89 \\
\hline ANDREA MASIELLO & ATALANTA & 73 & 74.89 \\
\hline FRANCO BRIENZA & BOLOGNA & 75 & 74.89 \\
\hline I.ABATE & MILAN & 77 & 74.84 \\
\hline MATIAS FERNANDEZ & FIORE & 76 & 74.84 \\
\hline RICCARDO MONTOLIVO & MILAN & 79 & 74.83 \\
\hline BLERIM DZEMAILI & GENOA & 72 & 74.83 \\
\hline JONATHAN BIABIANY & INTER & 77 & 74.82 \\
\hline MAXIMILIANO MORALEZ & ATALANTA & 76 & 74.82 \\
\hline FREDY GUARIN & INTER & 79 & 74.78 \\
\hline
\end{tabular}




\begin{tabular}{|c|c|c|c|}
\hline MAURICIO PINILLA & ATALANTA & 76 & 74.77 \\
\hline GABRIEL PALETTA & ATALANTA & 77 & 74.77 \\
\hline IVAN RADOVANOVIC & CHIEVO & 73 & 74.76 \\
\hline MANUEL PASQUAL & FIORE & 72 & 74.76 \\
\hline FABIO QUAGLIARELLA & SAMP & 78 & 74.74 \\
\hline LUIZ ADRIANO & MILAN & 79 & 74.71 \\
\hline KHOUMA BABACAR & FIORE & 75 & 74.69 \\
\hline ANDREA COSTA & EMPOLI & 74 & 74.67 \\
\hline KOSTAS MANOLAS & ROMA & 83 & 74.65 \\
\hline PERPARIM HETEMAJ & CHIEVO & 75 & 74.63 \\
\hline MAURO ZARATE & FIORE & 76 & 74.59 \\
\hline VINCENT LAURINI & EMPOLI & 71 & 74.55 \\
\hline DANILO CATALDI & LAZIO & 73 & 74.54 \\
\hline DUVAN ZAPATA & UDINESE & 77 & 74.54 \\
\hline NICOLA RIGONI & CHIEVO & 72 & 74.54 \\
\hline LUCA SILIGARDI & Verona & 73 & 74.50 \\
\hline FILIP DJORDJEVIC & LAZIO & 79 & 74.50 \\
\hline RADJA NAINGGOLAN & ROMA & 83 & 74.43 \\
\hline ALESSANDRO FLORENZI & ROMA & 79 & 74.43 \\
\hline L.CIGARINI & ATALANTA & 76 & 74.42 \\
\hline DAVIDE SANTON & INTER & 75 & 74.41 \\
\hline BRUNO FERNANDES & UDINESE & 75 & 74.40 \\
\hline JASMIN KURTIC & ATALANTA & 74 & 74.39 \\
\hline DOMENICO MAIETTA & BOLOGNA & 73 & 74.35 \\
\hline MATTEO POLITANO & SASSUOLO & 69 & 74.35 \\
\hline OMAR EL KADDOURI & NAPOLI & 77 & 74.34 \\
\hline FELIPE & UDINESE & 73 & 74.33 \\
\hline ANTONIO FLORO FLORES & SASSUOLO & 72 & 74.33 \\
\hline MAXI LOPEZ & TORINO & 77 & 74.28 \\
\hline ALEX & MILAN & 79 & 74.25 \\
\hline FERNANDO & SAMP & 70 & 74.22 \\
\hline FEDERICO VIVIANI & Verona & 73 & 74.20 \\
\hline MARCEL BUCHEL & EMPOLI & 71 & 74.16 \\
\hline JUAN JESUS & INTER & 75 & 74.13 \\
\hline ALEX FERRARI & BOLOGNA & 67 & 74.13 \\
\hline IAGO FALQUE & ROMA & 78 & 74.10 \\
\hline GIUSEPPE ROSSI & FIORE & 78 & 74.08 \\
\hline LUCA RIZZO & BOLOGNA & 71 & 74.08 \\
\hline
\end{tabular}




\begin{tabular}{|c|c|c|c|}
\hline ROBERTO INGLESE & CHIEVO & 70 & 74.08 \\
\hline GODFRED DONSAH & BOLOGNA & 73 & 74.07 \\
\hline RICCARDO GAGLIOLO & CARPI & 71 & 74.07 \\
\hline DIEGO PEROTTI & GENOA & 79 & 74.06 \\
\hline ALJAZ STRUNA & PALERMO & 67 & 74.04 \\
\hline ANTONIO DI GAUDIO & CARPI & 72 & 74.03 \\
\hline SUSO & GENOA & 75 & 74.03 \\
\hline GIAMPAOLO PAZZINI & Verona & 74 & 74.00 \\
\hline AMAURI & TORINO & 74 & 74.00 \\
\hline L.DIGNE & ROMA & 77 & 73.99 \\
\hline ACHRAF LAZAAR & PALERMO & 73 & 73.99 \\
\hline S.FLOCCARI & BOLOGNA & 73 & 73.98 \\
\hline KEISUKE HONDA & MILAN & 77 & 73.98 \\
\hline DAVID LOPEZ & NAPOLI & 76 & 73.90 \\
\hline ALESSANDRO GAMBERINI & CHIEVO & 77 & 73.88 \\
\hline MARCO D'ALESSANDRO & ATALANTA & 69 & 73.84 \\
\hline KEVIN LASAGNA & CARPI & 71 & 73.83 \\
\hline P.WSZOLEK & Verona & 72 & 73.81 \\
\hline VLAD CHIRICHES & NAPOLI & 76 & 73.79 \\
\hline A.CERCI & GENOA & 77 & 73.79 \\
\hline EDER & INTER & 79 & 73.78 \\
\hline MATTIA DE SCIGLIO & MILAN & 75 & 73.77 \\
\hline ALESSANDRO MATRI & LAZIO & 77 & 73.75 \\
\hline L.PASCIUTI & CARPI & 71 & 73.73 \\
\hline EMMANUEL BADU & UDINESE & 74 & 73.72 \\
\hline SALIH UCAN & ROMA & 73 & 73.7 \\
\hline SERGEJ MILINKOVIC-SAVIC & LAZIO & 75 & 73.70 \\
\hline SIMONE MISSIROLI & SASSUOLO & 75 & 73.70 \\
\hline K.STROOTMAN & ROMA & 80 & 73.65 \\
\hline GAETANO LETIZIA & CARPI & 72 & 73.63 \\
\hline S.SABELLI & CARPI & 67 & 73.62 \\
\hline JAKUB BLASZCZYKOWSKI & FIORE & 78 & 73.61 \\
\hline PANAGIOTIS KONE & UDINESE & 75 & 73.54 \\
\hline PANAGIOTIS TACHTSIDIS & GENOA & 74 & 73.53 \\
\hline EZEQUIEL MUNOZ & GENOA & 72 & 73.53 \\
\hline DANIELE BASELLI & TORINO & 78 & 73.51 \\
\hline DARIO DAINELLI & CHIEVO & 74 & 73.50 \\
\hline SERGE GAKPE' & GENOA & 74 & 73.49 \\
\hline
\end{tabular}




\begin{tabular}{|c|c|c|c|}
\hline PONTUS JANSSON & TORINO & 75 & 73.49 \\
\hline GERMAN DENIS & ATALANTA & 75 & 73.48 \\
\hline GERMAN DENIS & ATALANTA & 75 & 73.48 \\
\hline ANDREA BERTOLACCI & MILAN & 76 & 73.48 \\
\hline MATTEO BRIGHI & BOLOGNA & 70 & 73.47 \\
\hline ABDOULAY KONKO & LAZIO & 75 & 73.46 \\
\hline IBRAHIMA MBAYE & BOLOGNA & 68 & 73.44 \\
\hline MATO JAJALO & PALERMO & 72 & 73.43 \\
\hline MARCO BORRIELLO & ATALANTA & 74 & 73.42 \\
\hline LEONARDO BLANCHARD & FROSINONE & 71 & 73.42 \\
\hline BRUNO PERES & TORINO & 80 & 73.39 \\
\hline NICOLAS FREY & CHIEVO & 72 & 73.37 \\
\hline STEFANO MAURI & LAZIO & 79 & 73.37 \\
\hline SERGIO PELLISSIER & CHIEVO & 72 & 73.36 \\
\hline SINISA ANDELKOVIC & PALERMO & 74 & 73.35 \\
\hline KAMIL GLIK & TORINO & 82 & 73.35 \\
\hline R.ALVAREZ & SAMP & 77 & 73.32 \\
\hline ANDREA RISPOLI & PALERMO & 64 & 73.26 \\
\hline J.DE GUZMAN & CARPI & 76 & 73.24 \\
\hline LORENZO LOLLO & CARPI & 71 & 73.22 \\
\hline STEFAN RADU & LAZIO & 79 & 73.21 \\
\hline MARKO LIVAJA & EMPOLI & 69 & 73.21 \\
\hline MARIO BALOTELLI & MILAN & 79 & 73.18 \\
\hline SIMONE ROMAGNOLI & CARPI & 70 & 73.15 \\
\hline JUANITO GOMEZ & Verona & 73 & 73.13 \\
\hline DIEGO FALCINELLI & SASSUOLO & 69 & 73.08 \\
\hline MIRKO VALDIFIORI & NAPOLI & 76 & 73.06 \\
\hline IVAYLO CHOCHEV & PALERMO & 70 & 73.05 \\
\hline U.EMANUELSON & Verona & 74 & 73.05 \\
\hline CHRISTIAN MAGGIO & NAPOLI & 75 & 73.02 \\
\hline CRISTIAN ZACCARDO & CARPI & 73 & 72.99 \\
\hline DANIELE CROCE & EMPOLI & 74 & 72.99 \\
\hline DANIELE CROCE & EMPOLI & 74 & 72.99 \\
\hline ANDREA LAZZARI & CARPI & 72 & 72.97 \\
\hline RAMAN CHIBSAH & FROSINONE & 68 & 72.97 \\
\hline SAMUELE LONGO & FROSINONE & 69 & 72.96 \\
\hline ROBIN QUAISON & PALERMO & 73 & 72.95 \\
\hline OGENYI ONAZI & LAZIO & 75 & 72.88 \\
\hline
\end{tabular}




\begin{tabular}{|c|c|c|c|}
\hline AFRIYIE ACQUAH & TORINO & 73 & 72.84 \\
\hline SILVAN WIDMER & UDINESE & 75 & 72.82 \\
\hline GORAN PANDEV & GENOA & 74 & 72.82 \\
\hline SERGIO FLOCCARI & SASSUOLO & 73 & 72.82 \\
\hline EDENILSON & UDINESE & 74 & 72.81 \\
\hline JERRY MBAKOGU & CARPI & 73 & 72.81 \\
\hline V.REGINI & NAPOLI & 71 & 72.80 \\
\hline K. BOATENG & MILAN & 77 & 72.80 \\
\hline A. TABACCHI & BOLOGNA & 67 & 72.78 \\
\hline ALEKSANDAR TRAJKOVSKI & PALERMO & 67 & 72.74 \\
\hline LUCA RIGONI & GENOA & 73 & 72.74 \\
\hline ANDREA POLI & MILAN & 75 & 72.72 \\
\hline RICARDO KISHNA & LAZIO & 75 & 72.70 \\
\hline MARTIN MONTOYA & INTER & 78 & 72.69 \\
\hline MATTEO MANCOSU & BOLOGNA & 70 & 72.68 \\
\hline A.FLORO FLORES & CHIEVO & 72 & 72.67 \\
\hline IVAN STRINIC & NAPOLI & 73 & 72.67 \\
\hline RAFAEL MARQUEZ & Verona & 76 & 72.65 \\
\hline LUCA PAGANINI & FROSINONE & 65 & 72.64 \\
\hline OLIVIER NTCHAM & GENOA & 64 & 72.63 \\
\hline FEDERICO BARBA & EMPOLI & 71 & 72.62 \\
\hline ANGELO PALOMBO & SAMP & 71 & 72.62 \\
\hline MARCO ZAMBELLI & EMPOLI & 68 & 72.61 \\
\hline DANIELE DE ROSSI & ROMA & 82 & 72.59 \\
\hline S.GAKPE & ATALANTA & 74 & 72.57 \\
\hline R.FREULER & ATALANTA & 67 & 72.56 \\
\hline B.CRISTANTE & PALERMO & 72 & 72.55 \\
\hline ALESSIO CERCI & MILAN & 77 & 72.53 \\
\hline J.OBI & TORINO & 72 & 72.53 \\
\hline RODRIGO AGUIRRE & UDINESE & 67 & 72.53 \\
\hline GIAMPIERO PINZI & CHIEVO & 73 & 72.53 \\
\hline ANDREA RANOCCHIA & INTER & 77 & 72.53 \\
\hline DANIEL PAVLOVIC' & FROSINONE & 65 & 72.51 \\
\hline ERICK PULGAR & BOLOGNA & 68 & 72.50 \\
\hline MARCO BENASSI & TORINO & 75 & 72.48 \\
\hline CHRISTIAN ZAPATA & MILAN & 76 & 72.46 \\
\hline LORENZO PELLEGRINI & SASSUOLO & 65 & 72.44 \\
\hline GUILHERME & UDINESE & 74 & 72.44 \\
\hline
\end{tabular}




\begin{tabular}{|c|c|c|c|}
\hline GERMAN DENIS & ATALANTA & 75 & 72.44 \\
\hline GERMAN DENIS & ATALANTA & 75 & 72.44 \\
\hline RAFFAELE BIANCO & CARPI & 69 & 72.44 \\
\hline SUSO & MILAN & 75 & 72.43 \\
\hline ISAAC COFIE & CARPI & 71 & 72.40 \\
\hline LEVAN MCHEDLIDZE & EMPOLI & 71 & 72.39 \\
\hline N.SPOLLI & CHIEVO & 74 & 72.39 \\
\hline ROMULO & Verona & 73 & 72.39 \\
\hline IVAN PIRIS & UDINESE & 75 & 72.37 \\
\hline GUGLIELMO STENDARDO & ATALANTA & 74 & 72.37 \\
\hline M.WAGUE & UDINESE & 73 & 72.34 \\
\hline GILBERTO & FIORE & 69 & 72.33 \\
\hline JOAQUIN CORREA & SAMP & 71 & 72.32 \\
\hline U. COSIC & EMPOLI & 68 & 72.32 \\
\hline A. FARNERUD & TORINO & 72 & 72.29 \\
\hline J.ZUNIGA & BOLOGNA & 72 & 72.27 \\
\hline J.MENEZ & MILAN & 81 & 72.27 \\
\hline NIGEL DE JONG & MILAN & 77 & 72.24 \\
\hline T. MATAVZ & GENOA & 72 & 72.22 \\
\hline GIUSEPPE VIVES & TORINO & 74 & 72.22 \\
\hline LORENZO CRISETIG & BOLOGNA & 71 & 72.21 \\
\hline ALEKSANDAR TONEV & FROSINONE & 67 & 72.21 \\
\hline TINO COSTA & GENOA & 76 & 72.20 \\
\hline STIPE PERICA & UDINESE & 70 & 72.17 \\
\hline ISSA CISSOKHO & GENOA & 73 & 72.17 \\
\hline DANILO SODDIMO & FROSINONE & 68 & 72.16 \\
\hline GASTON BRUGMAN & PALERMO & 68 & 72.16 \\
\hline FRANCESCO LODI & UDINESE & 73 & 72.14 \\
\hline DANILO AVELAR & TORINO & 75 & 72.13 \\
\hline FILIPPO FALCO & BOLOGNA & 64 & 72.12 \\
\hline ANDREA CONTI & ATALANTA & 67 & 72.11 \\
\hline LUCA RIGONI & PALERMO & 73 & 72.10 \\
\hline GIOVANNI MARCHESE & GENOA & 74 & 72.08 \\
\hline DANIELE CROCE & EMPOLI & 74 & 72.07 \\
\hline DANIELE CROCE & EMPOLI & 74 & 72.07 \\
\hline PAOLO SAMMARCO & FROSINONE & 68 & 72.06 \\
\hline KARIM LARIBI & SASSUOLO & 69 & 72.05 \\
\hline EROS PISANO & Verona & 72 & 72.04 \\
\hline
\end{tabular}




\begin{tabular}{|c|c|c|c|}
\hline DANIELE VERDE & FROSINONE & 69 & 72.02 \\
\hline GIOVANNI PASQUALE & UDINESE & 69 & 72.01 \\
\hline NENAD KRSTICIC & SAMP & 72 & 72.00 \\
\hline MARQUINHO & UDINESE & 76 & 72.00 \\
\hline PAWL WSZOLEK & SAMP & 72 & 72.00 \\
\hline RAFFAELE MAIELLO & EMPOLI & 66 & 71.99 \\
\hline MATTEO FEDELE & CARPI & 67 & 71.97 \\
\hline NICOLO' CHERUBIN & ATALANTA & 72 & 71.96 \\
\hline MATTEO BIANCHETTI & Verona & 71 & 71.95 \\
\hline DIEGO CAPEL & GENOA & 75 & 71.93 \\
\hline GIANPAOLO BELLINI & ATALANTA & 68 & 71.92 \\
\hline JUAN ITURBE & ROMA & 77 & 71.92 \\
\hline F.HELANDER & Verona & 73 & 71.91 \\
\hline ALBERTO GRASSI & ATALANTA & 70 & 71.90 \\
\hline ALESSANDRO FRARA & FROSINONE & 67 & 71.89 \\
\hline EDOARDO GOLDANIGA & PALERMO & 70 & 71.87 \\
\hline G.MONACHELLO & ATALANTA & 66 & 71.84 \\
\hline MIRKO GORI & FROSINONE & 66 & 71.84 \\
\hline MASSIMILIANO CARLINI & FROSINONE & 67 & 71.82 \\
\hline NICOLAS CASTILLO & FROSINONE & 73 & 71.81 \\
\hline DAVIDE BIONDINI & SASSUOLO & 70 & 71.81 \\
\hline J.SALA & SAMP & 72 & 71.80 \\
\hline JURAJ KUCKA & GENOA & 77 & 71.79 \\
\hline ARCHIMEDE MORLEO & BOLOGNA & 70 & 71.79 \\
\hline LUCA MARONE & CARPI & 70 & 71.78 \\
\hline EVANGELOS MORAS & Verona & 74 & 71.77 \\
\hline DAVIDE BRIVIO & ATALANTA & 72 & 71.76 \\
\hline MATTIA CASSANI & SAMP & 72 & 71.75 \\
\hline MICHEL MORGANELLA & PALERMO & 67 & 71.73 \\
\hline G.SILVA & GENOA & 70 & 71.73 \\
\hline MANUEL ITURRA & UDINESE & 74 & 71.72 \\
\hline ANTONIO NOCERINO & MILAN & 72 & 71.71 \\
\hline ALEANDRO ROSI & FROSINONE & 70 & 71.68 \\
\hline CRISTIAN RAIMONDI & ATALANTA & 67 & 71.65 \\
\hline K.CONSTANT & BOLOGNA & 71 & 71.64 \\
\hline GIULIO MIGLIACCIO & ATALANTA & 71 & 71.63 \\
\hline ENZO MARESCA & PALERMO & 74 & 71.61 \\
\hline M.MANCOSU & CARPI & 70 & 71.60 \\
\hline
\end{tabular}




\begin{tabular}{|c|c|c|c|}
\hline GENNARO SARDO & CHIEVO & 66 & 71.56 \\
\hline CARLOS CARMONA & ATALANTA & 74 & 71.56 \\
\hline WALLACE & CARPI & 67 & 71.55 \\
\hline S.VERDI & CARPI & 71 & 71.55 \\
\hline MAICON & ROMA & 77 & 71.50 \\
\hline JOSE' MAURI & MILAN & 72 & 71.48 \\
\hline MARCELLO GAZZOLA & SASSUOLO & 66 & 71.47 \\
\hline MATIAS SILVESTRE & SAMP & 73 & 71.47 \\
\hline M.CRIMI & CARPI & 66 & 71.45 \\
\hline R. FIAMOZZI & GENOA & 65 & 71.45 \\
\hline L.ANTEI & SASSUOLO & 71 & 71.44 \\
\hline LUCA BITTANTE & EMPOLI & 67 & 71.43 \\
\hline R.MARTINHO & CARPI & 72 & 71.43 \\
\hline L.MARONE & Verona & 70 & 71.42 \\
\hline GABRIEL SILVA & CARPI & 70 & 71.40 \\
\hline JACOPO SALA & Verona & 72 & 71.37 \\
\hline EMIL HALLFREDSSON & Verona & 74 & 71.37 \\
\hline EDGAR BARRETO & SAMP & 73 & 71.32 \\
\hline L. DE SILVESTRI & SAMP & 76 & 71.23 \\
\hline EDSON BRAAFHEID & LAZIO & 72 & 71.22 \\
\hline PHILIPPE MEXES & MILAN & 77 & 71.15 \\
\hline ALESSANDRO GAZZI & TORINO & 74 & 71.09 \\
\hline Z.KUZMANOVIC & UDINESE & 74 & 71.09 \\
\hline FRANCELINO MATUZALEM & Verona & 71 & 71.00 \\
\hline FEDERICO MATTIELLO & CHIEVO & 71 & 71.00 \\
\hline CESARE BOVO & TORINO & 75 & 70.99 \\
\hline NIKLAS MOISANDER & SAMP & 74 & 70.99 \\
\hline PEDRO PEREIRA & SAMP & 65 & 70.98 \\
\hline DAVID IVAN & SAMP & 67 & 70.96 \\
\hline CRISTIAN MOLINARO & TORINO & 75 & 70.88 \\
\hline EMERSON & ROMA & 68 & 70.86 \\
\hline THOMAS HEURTAUX & UDINESE & 77 & 70.85 \\
\hline EMANUELE TERRANOVA & SASSUOLO & 70 & 70.84 \\
\hline ABDELHAMID EL KAOUTARI & PALERMO & 73 & 70.82 \\
\hline B.DJIMSITI & ATALANTA & 62 & 70.80 \\
\hline STEFAN DE VRIJ & LAZIO & 81 & 70.79 \\
\hline LORENZO ARIAUDO & SASSUOLO & 71 & 70.78 \\
\hline MARCELO ESTIGARRIBIA & ATALANTA & 73 & 70.72 \\
\hline
\end{tabular}




\begin{tabular}{|c|c|c|c|}
\hline A.CODA & SAMP & 70 & 70.69 \\
\hline ROBERTO CRIVELLO & FROSINONE & 67 & 70.68 \\
\hline RODRIGO ELY & MILAN & 70 & 70.67 \\
\hline BOSKO JANKOVIC & Verona & 73 & 70.66 \\
\hline ROBERT GUCHER & FROSINONE & 70 & 70.63 \\
\hline DODO & SAMP & 73 & 70.56 \\
\hline ROBERTO VITIELLO & PALERMO & 72 & 70.55 \\
\hline ERVIN ZUKANOVIC & SAMP & 71 & 70.55 \\
\hline T.CIONEK & PALERMO & 70 & 70.54 \\
\hline FABIO DAPRELA & PALERMO & 67 & 70.51 \\
\hline E.ZUKANOVIC & ROMA & 74 & 70.46 \\
\hline M.DOMIZZI & UDINESE & 73 & 70.42 \\
\hline MATTEO CIOFANI & FROSINONE & 68 & 70.37 \\
\hline M.FARES & Verona & 65 & 70.32 \\
\hline DAVIDE ZAPPACOSTA & TORINO & 76 & 70.29 \\
\hline E.SUAGHER & CARPI & 70 & 70.26 \\
\hline DAVIDE BERTONCINI & FROSINONE & 61 & 70.25 \\
\hline GASTON SILVA & TORINO & 70 & 70.24 \\
\hline LEANDRO GRECO & Verona & 72 & 70.22 \\
\hline F.POLI & CARPI & 68 & 70.14 \\
\hline ANDREA RANOCHIA & SAMP & 77 & 70.12 \\
\hline NICOLAS SPOLLI & CARPI & 74 & 70.12 \\
\hline NIKOLA MAKSIMOVIC & TORINO & 80 & 70.08 \\
\hline LEANDRO CASTAN & ROMA & 79 & 70.07 \\
\hline ROBERT ACQUAFRESCA & BOLOGNA & 68 & 70.06 \\
\hline PIERLUIGI GOLLINI & Verona & 70 & 70.00 \\
\hline IGOR BUBNJIC & CARPI & 72 & 69.94 \\
\hline VASSILIS TOROSIDIS & ROMA & 76 & 69.93 \\
\hline ADRIANO RUSSO & FROSINONE & 67 & 69.92 \\
\hline O.KRAGL & FROSINONE & 66 & 69.88 \\
\hline ANTE REBIC' & FIORE & 69 & 69.83 \\
\hline MICHELE CAMPORESE & EMPOLI & 67 & 69.81 \\
\hline DJAMEL MESBAH & SAMP & 71 & 69.80 \\
\hline A.REBIC & Verona & 69 & 69.78 \\
\hline VASCO REGINI & SAMP & 71 & 69.76 \\
\hline $\begin{array}{l}\text { MICHELANGELO } \\
\text { ALBERTAZZI }\end{array}$ & Verona & 67 & 69.75 \\
\hline MOBIDO DIAKITE & SAMP & 75 & 69.64 \\
\hline FRANCO SIGNORELLI & EMPOLI & 68 & 69.36 \\
\hline
\end{tabular}




\begin{tabular}{llll|}
\hline ASSANE GNOUKOURI & INTER & 69 & 69.06 \\
\hline T.COSTA & FIORE & 71 & 69.04 \\
\hline GILBERTO & Verona & 69 & 69.00 \\
\hline LUIGI GIORGI & ATALANTA & 67 & 68.90 \\
\hline KAMIL WILCZEK & CARPI & 70 & 68.81 \\
\hline RONALDO & EMPOLI & 62 & 68.61 \\
\hline F.DAPRELA & CARPI & 67 & 68.38 \\
\hline SAMUEL SOUPRAYEN & Verona & 70 & 67.94 \\
\hline S.LONGO & FROSINONE & 69 & 67.89 \\
\hline EMIL KRAFTH & BOLOGNA & 67 & 67.76 \\
\hline F.ZUCULINI & BOLOGNA & 70 & 66.84 \\
\hline M.ZAMBELLI & EMPOLI & 68 & 66.78 \\
\hline ALEXANDER MERKEL & UDINESE & 68 & 66.69 \\
\hline N.NINKOVIC & CHIEVO & 68 & 66.49 \\
\hline M.TROTTA & SASSUOLO & 68 & 66.30 \\
\hline D.FURMAN & Verona & 66 & 66.00 \\
\hline FEDERICO BONAZZOLI & SAMP & 62 & 65.12 \\
\hline SADIQ & ROMA & 63 & 63.69 \\
\hline LUCA MARTINELLI & EMPOLI & 63 & 63.00 \\
\hline ALEJANDRO RODRIGUEZ & SAMP & 66 & 62.80 \\
\hline ANTONINO LA GUMINA & PALERMO & 58 & 60.32 \\
\hline A.BENTIVEGNA & PALERMO & 57 & 57.18 \\
\hline A. FAVILLI & JUVENTUS & 53 & 52.94 \\
\hline & & & \\
\hline
\end{tabular}

It must be mentioned that to get Table 22 above, the Neural Network algorithm was repeated 1000 times for each number of hidden nodes ranging from 1 to 10 . This was performed in order to find the number of nodes in the hidden layer that generated the lowest SSE. Additionally, the algorithm was also run with more than 10 nodes in the hidden layer, just to see what the best number of nodes in the hidden layer might be. 
Below are some players for whom there were substantial differences from their FIFA scores The young star Paulo Dybala from Juventus was bought from Palermo for $40 \mathrm{M} €$ when he was only 21 years old. At the time he was showing promise of becoming a talented player. During his first season he scored 19 goals and had 9 assists, therefore indicating this money was well spent. Our scoring results are based solely on the 2015-16 season and score him higher than his EASports FIFA score. That latter score is based on historical data and does not capture his improved performance.

Another player chosen for further examination was Gonzalo Higuain. One should note that the predicted score for Higuain of 86.69 from the Neural Network model was almost equivalent to the score generated from the EASports' scores which was 86. However, Higuain was chosen because of his phenomenal performance - during the 2015-2016 season, Higuain set a record for most goals scored by a player in a single season.

The next player is Georgio Chiellini. He is one of the best defenders among the squad, based on the FIFA scores. But the model shows a drop of five points for the 2015-2016 season. This may be related to the fact that he was injured most of the season and he could not play as much as other defenders.

The summary of the NNet Model4 model is presented as follows: 
a 7-10-1 network with 91 weights options were - linear output units

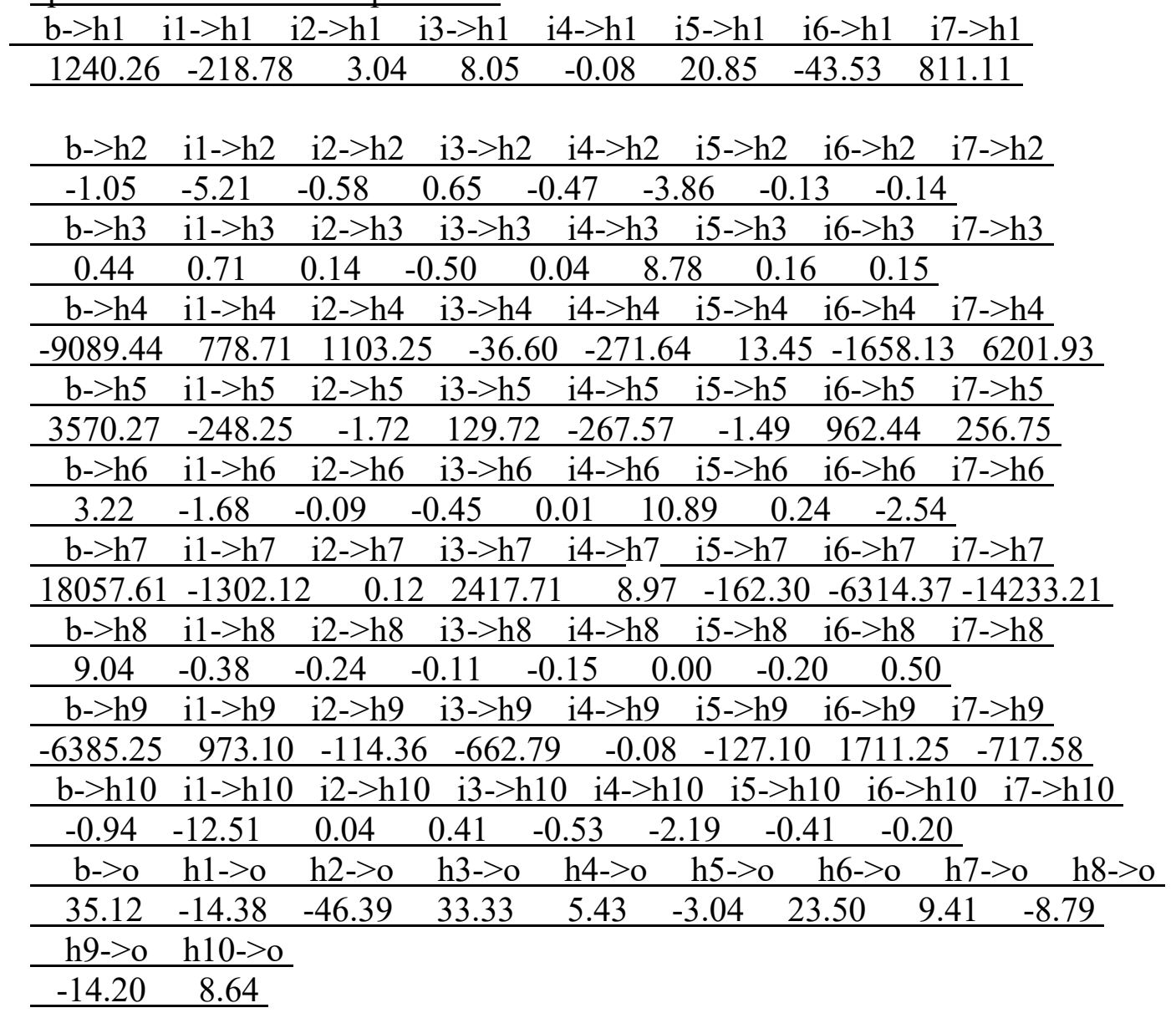

\subsubsection{Scoring/Ranking Model: Using Ordinal Regression Modelling}

The same data set was used for ordinal regression modelling as for Neural Network modelling. The function "orm" (Ordinal Regression Model) in the R package rms was used.

As per Leard [28] there are four assumptions that must hold in order to perform ORM. First, the dependent variable must be measured at ordinal levels. The 
second assumption is that the predictor variables must be continuous, ordinal or categorical. The third assumption is that there should not be any multicollinearity among the predictor variables. Lastly, we require the assumption of proportional odds. This requires that each predictor variable has an identical effect at each cumulative split of the ordinal dependent variable (parallelism) [28]. The last assumption has been tested using the Brant Package and none of the variables reached our significance level hence [29] all assumptions are met, and we can continue with the model. (The threshold for this analysis was 0.05 .)

H0: The assumption of parallelism holds

H1: The assumption of parallelism does not hold

\begin{tabular}{|lr|}
\hline Variables & \multicolumn{1}{|c|}{ P-value } \\
\hline Omnibus & 0.003 \\
\hline $\begin{array}{l}\text { Overall Clean } \\
\text { Sheet }\end{array}$ & 0.07 \\
\hline Overall Assists & 0.54 \\
\hline Overall Cards & 0.30 \\
\hline Overall Goal & 0.27 \\
\hline Overall time & 0.82 \\
\hline
\end{tabular}


The summary of the ORM is

\begin{tabular}{|lr|}
\hline Min & -2.87 \\
\hline 1st Quarter & -0.62 \\
\hline Median & 0.19 \\
\hline Mean & 0.36 \\
\hline 3rd Quarter & 1.08 \\
\hline Max & 6.82 \\
\hline
\end{tabular}

The latent variable results using ORM are shown in the table below:

Table 23:Ordinal Regression Model compared to FIFA Score

\begin{tabular}{|c|c|c|c|c|}
\hline Player & Team & $\begin{array}{l}\text { FIFA } \\
\text { Rating }\end{array}$ & $\begin{array}{l}\text { Latent } \\
\text { Variable }\end{array}$ & $\begin{array}{l}\text { Transferred } \\
\text { Values }\end{array}$ \\
\hline P. DYBALA & JUVENTUS & 81 & 6.82 & 85.95 \\
\hline GONZALO HIGUAIN & NAPOLI & 86 & 6.56 & 85.07 \\
\hline P. POGBA & JUVENTUS & 86 & 6.09 & 83.49 \\
\hline LORENZO INSIGNE & NAPOLI & 82 & 5.06 & 79.99 \\
\hline MAREK HAMSIK & NAPOLI & 82 & 4.74 & 78.90 \\
\hline M. MANDZUKIC & JUVENTUS & 82 & 4.47 & 77.98 \\
\hline MAURO ICARDI & INTER & 80 & 4.40 & 77.73 \\
\hline A. MORATA & JUVENTUS & 80 & 4.30 & 77.39 \\
\hline JOSE' CALLEJON & NAPOLI & 81 & 4.04 & 76.51 \\
\hline CARLOS BACCA & MILAN & 82 & 3.95 & 76.19 \\
\hline JUAN CUADRADO & JUVENTUS & 81 & 3.82 & 75.76 \\
\hline MASSIMO & & & & \\
\hline MACCARONE & EMPOLI & 75 & 3.73 & 75.45 \\
\hline I.PERISIC & INTER & 81 & 3.60 & 74.99 \\
\hline L. BONUCCI & JUVENTUS & 83 & 3.49 & 74.63 \\
\hline MIRALEM PJANIC & ROMA & 84 & 3.44 & 74.47 \\
\hline RICCARDO & & & & \\
\hline SAPONARA & EMPOLI & 78 & 3.36 & 74.20 \\
\hline ALEJANDRO GOMEZ & ATALANTA & 78 & 3.33 & 74.08 \\
\hline MOHAMED SALAH & ROMA & 80 & 3.29 & 73.95 \\
\hline JOSIP ILICIC & FIORE & 80 & 3.28 & 73.93 \\
\hline BORJA VALERO & FIORE & 82 & 3.27 & 73.90 \\
\hline SAMI KHEDIRA & JUVENTUS & 81 & 3.23 & 73.75 \\
\hline P. EVRA & JUVENTUS & 81 & 3.15 & 73.49 \\
\hline FRANCO VAZQUEZ & PALERMO & 80 & 3.15 & 73.48 \\
\hline
\end{tabular}




\begin{tabular}{|c|c|c|c|c|}
\hline \multicolumn{5}{|l|}{ LEONARDO } \\
\hline PAVOLETTI & GENOA & 75 & 3.01 & 72.99 \\
\hline BONAVENTURA & MILAN & 80 & 3.00 & 72.96 \\
\hline A. BARZAGLI & JUVENTUS & 85 & 2.95 & 72.79 \\
\hline ALLAN & NAPOLI & 80 & 2.88 & 72.58 \\
\hline \multicolumn{5}{|l|}{ MANUEL } \\
\hline PUCCIARELLI & EMPOLI & 73 & 2.86 & 72.49 \\
\hline VALTER BIRSA & CHIEVO & 75 & 2.75 & 72.13 \\
\hline CYRIL THEREAU & UDINESE & 77 & 2.71 & 71.98 \\
\hline \multicolumn{5}{|l|}{ ANTONIO } \\
\hline CANDREVA & LAZIO & 81 & 2.68 & 71.89 \\
\hline ALEX SANDRO & JUVENTUS & 82 & 2.65 & 71.78 \\
\hline MARCELO BROZOVIC & INTER & 78 & 2.63 & 71.70 \\
\hline DOMENICO BERARDI & SASSUOLO & 81 & 2.59 & 71.59 \\
\hline MIROSLAV KLOSE & LAZIO & 79 & 2.55 & 71.44 \\
\hline PIOTR ZIELINSKI & EMPOLI & 74 & 2.52 & 71.35 \\
\hline MATTIA DESTRO & BOLOGNA & 76 & 2.51 & 71.30 \\
\hline \multicolumn{5}{|l|}{ CLAUDIO } \\
\hline MARCHISIO & JUVENTUS & 84 & 2.51 & 71.30 \\
\hline FELIPE ANDERSON & LAZIO & 79 & 2.49 & 71.23 \\
\hline NICOLA SANSONE & SASSUOLO & 77 & 2.43 & 71.04 \\
\hline DIEGO LAXALT & GENOA & 73 & 2.41 & 70.98 \\
\hline TOMAS RINCON & GENOA & 75 & 2.40 & 70.94 \\
\hline \multicolumn{5}{|l|}{ RICCARDO } \\
\hline MEGGIORINI & CHIEVO & 75 & 2.38 & 70.87 \\
\hline S. LICHTSTEINER & JUVENTUS & 82 & 2.33 & 70.71 \\
\hline ELSEID HYSAJ & NAPOLI & 77 & 2.33 & 70.70 \\
\hline \multicolumn{5}{|l|}{ FEDERICO } \\
\hline BERNARDESCHI & FIORE & 77 & 2.32 & 70.65 \\
\hline FAOUZI GHOULAM & NAPOLI & 78 & 2.31 & 70.63 \\
\hline ANDREA BELOTTI & TORINO & 75 & 2.30 & 70.59 \\
\hline JORGINHO & NAPOLI & 79 & 2.30 & 70.58 \\
\hline DRIES MERTENS & NAPOLI & 81 & 2.22 & 70.32 \\
\hline OSCAR HILEMARK & PALERMO & 72 & 2.22 & 70.31 \\
\hline MARCOS ALONSO & FIORE & 75 & 2.21 & 70.27 \\
\hline G. CHIELLINI & JUVENTUS & 86 & 2.21 & 70.27 \\
\hline MIRANDA & INTER & 85 & 2.21 & 70.27 \\
\hline RAUL ALBIOL & NAPOLI & 81 & 2.15 & 70.09 \\
\hline EDIN DZEKO & ROMA & 80 & 2.15 & 70.08 \\
\hline SIMONE ZAZA & JUVENTUS & 79 & 2.14 & 70.03 \\
\hline \multicolumn{5}{|l|}{ GONZALO } \\
\hline RODRIGUEZ & FIORE & 81 & 2.12 & 69.97 \\
\hline GREGOIRE DEFREL & SASSUOLO & 73 & 2.07 & 69.80 \\
\hline
\end{tabular}




\begin{tabular}{|c|c|c|c|c|}
\hline STEVAN JOVETIC & INTER & 80 & 1.95 & 69.42 \\
\hline FEDERICO DIONISI & FROSINONE & 72 & 1.95 & 69.39 \\
\hline ALBERTO PALOSCHI & CHIEVO & 77 & 1.94 & 69.38 \\
\hline ADAM MASINA & BOLOGNA & 73 & 1.92 & 69.30 \\
\hline RODRIGO PALACIO & INTER & 79 & 1.91 & 69.28 \\
\hline JEISON MURILLO & INTER & 79 & 1.88 & 69.17 \\
\hline ROBERTO SORIANO & SAMP & 76 & 1.86 & 69.10 \\
\hline DANIEL CIOFANI & FROSINONE & 72 & 1.86 & 69.08 \\
\hline SIME VRSALJKO & SASSUOLO & 77 & 1.80 & 68.90 \\
\hline MARIO RUI & EMPOLI & 76 & 1.76 & 68.74 \\
\hline DANIELE RUGANI & JUVENTUS & 78 & 1.75 & 68.71 \\
\hline FRANCESCO ACERBI & SASSUOLO & 79 & 1.74 & 68.70 \\
\hline HERNANES & JUVENTUS & 80 & 1.72 & 68.63 \\
\hline \multicolumn{5}{|l|}{ ALESSANDRO } \\
\hline FLORENZI & ROMA & 79 & 1.72 & 68.61 \\
\hline \multicolumn{5}{|l|}{ MANOLO } \\
\hline GABBIADINI & NAPOLI & 78 & 1.67 & 68.44 \\
\hline R. PEREYRA & JUVENTUS & 80 & 1.65 & 68.39 \\
\hline S. STURARO & JUVENTUS & 77 & 1.65 & 68.37 \\
\hline LUCA ROSSETTINI & BOLOGNA & 74 & 1.64 & 68.36 \\
\hline ADAM LJAJIC & INTER & 79 & 1.61 & 68.26 \\
\hline LUCAS BIGLIA & LAZIO & 81 & 1.59 & 68.19 \\
\hline MARIO LEMINA & JUVENTUS & 76 & 1.59 & 68.17 \\
\hline KALIDOU KOULIBALY & NAPOLI & 80 & 1.58 & 68.15 \\
\hline SENAD LULIC & LAZIO & 77 & 1.58 & 68.13 \\
\hline \multicolumn{5}{|l|}{ EMANUELE } \\
\hline GIACCHERINI & BOLOGNA & 77 & 1.57 & 68.11 \\
\hline ALFRED DUNCAN & SASSUOLO & 73 & 1.56 & 68.06 \\
\hline C.TELLO & FIORE & 78 & 1.55 & 68.05 \\
\hline GARY MEDEL & INTER & 81 & 1.55 & 68.05 \\
\hline \multicolumn{5}{|l|}{ KWADWO } \\
\hline ASAMOAH & JUVENTUS & 79 & 1.54 & 68.00 \\
\hline DAVIDE ASTORI & FIORE & 79 & 1.53 & 67.98 \\
\hline KEITA & LAZIO & 77 & 1.51 & 67.90 \\
\hline MARTEN DE ROON & ATALANTA & 76 & 1.50 & 67.87 \\
\hline MATIAS VECINO & FIORE & 75 & 1.50 & 67.86 \\
\hline ANTHONY MOUNIER & BOLOGNA & 76 & 1.47 & 67.76 \\
\hline LUCAS CASTRO & CHIEVO & 75 & 1.46 & 67.75 \\
\hline \multicolumn{5}{|l|}{ FABRIZIO } \\
\hline CACCIATORE & CHIEVO & 72 & 1.45 & 67.69 \\
\hline M'BAYE NIANG & MILAN & 75 & 1.43 & 67.62 \\
\hline FRANCO BRIENZA & BOLOGNA & 75 & 1.42 & 67.59 \\
\hline
\end{tabular}




\begin{tabular}{|c|c|c|c|c|}
\hline SIMONE PADOIN & JUVENTUS & 74 & 1.41 & 67.55 \\
\hline LUIS MURIEL & SAMP & 75 & 1.41 & 67.55 \\
\hline CRISTIAN ANSALDI & GENOA & 79 & 1.35 & 67.36 \\
\hline \multicolumn{5}{|l|}{ RADJA } \\
\hline L.DIGNE & ROMA & 77 & 1.34 & 67.33 \\
\hline \multicolumn{5}{|l|}{ FRANCESCO } \\
\hline MAGNANELLI & SASSUOLO & 76 & 1.34 & 67.31 \\
\hline FEDERICO PELUSO & SASSUOLO & 73 & 1.33 & 67.30 \\
\hline EDER & SAMP & 79 & 1.33 & 67.29 \\
\hline \multicolumn{5}{|l|}{ DANIELE } \\
\hline GASTALDELLO & BOLOGNA & 76 & 1.31 & 67.24 \\
\hline D.PEROTTI & ROMA & 79 & 1.30 & 67.20 \\
\hline \multicolumn{5}{|l|}{ FACUNDO } \\
\hline RONCAGLIA & FIORE & 75 & 1.29 & 67.17 \\
\hline DUVAN ZAPATA & UDINESE & 77 & 1.27 & 67.10 \\
\hline MASSIMO GOBBI & CHIEVO & 73 & 1.27 & 67.07 \\
\hline MARTIN CACERES & JUVENTUS & 80 & 1.26 & 67.07 \\
\hline KINGSLEY COMAN & JUVENTUS & 78 & 1.25 & 67.03 \\
\hline \multicolumn{5}{|l|}{ FERNANDO } \\
\hline LLORENTE & JUVENTUS & 80 & 1.22 & 66.92 \\
\hline LUCA ANTONELLI & MILAN & 77 & 1.21 & 66.89 \\
\hline MARCO PAROLO & LAZIO & 80 & 1.19 & 66.81 \\
\hline MILAN BADELJ & FIORE & 78 & 1.16 & 66.72 \\
\hline LEANDRO PAREDES & EMPOLI & 74 & 1.16 & 66.70 \\
\hline LUIZ ADRIANO & MILAN & 79 & 1.14 & 66.64 \\
\hline KHOUMA BABACAR & FIORE & 75 & 1.14 & 66.64 \\
\hline ARMANDO IZZO & GENOA & 74 & 1.13 & 66.60 \\
\hline BRUNO FERNANDES & UDINESE & 75 & 1.12 & 66.57 \\
\hline EMMANUEL BADU & UDINESE & 74 & 1.09 & 66.47 \\
\hline FELIPE MELO & INTER & 79 & 1.08 & 66.45 \\
\hline FILIP DJORDJEVIC & LAZIO & 79 & 1.08 & 66.44 \\
\hline \multicolumn{5}{|l|}{ GEOFFREY } \\
\hline KONDOGBIA & INTER & 76 & 1.07 & 66.42 \\
\hline BOSTJAN CESAR & CHIEVO & 77 & 1.07 & 66.41 \\
\hline MAURICIO PINILLA & ATALANTA & 76 & 1.06 & 66.39 \\
\hline KOSTAS MANOLAS & ROMA & 83 & 1.05 & 66.35 \\
\hline \multicolumn{5}{|l|}{ DANILO } \\
\hline D'AMBROSIO & INTER & 74 & 1.04 & 66.30 \\
\hline KEISUKE HONDA & MILAN & 77 & 1.02 & 66.23 \\
\hline BLERIM DZEMAILI & GENOA & 72 & 1.01 & 66.21 \\
\hline \multicolumn{5}{|l|}{ RICCARDO } \\
\hline MONTOLIVO & MILAN & 79 & 1.00 & 66.17 \\
\hline
\end{tabular}




\begin{tabular}{|c|c|c|c|c|}
\hline JURAJ KUCKA & MILAN & 77 & 1.00 & 66.17 \\
\hline PAOLO CANNAVARO & SASSUOLO & 75 & 0.97 & 66.08 \\
\hline NICOLA RIGONI & CHIEVO & 72 & 0.97 & 66.07 \\
\hline \multicolumn{5}{|l|}{ ALESSIO } \\
\hline ROMAGNOLI & MILAN & 76 & 0.97 & 66.06 \\
\hline MAURICIO ISLA & JUVENTUS & 75 & 0.97 & 66.06 \\
\hline FERNANDO & SAMP & 70 & 0.96 & 66.05 \\
\hline SAPHIR TAIDER & BOLOGNA & 73 & 0.96 & 66.02 \\
\hline ALEX TELLES & INTER & 76 & 0.93 & 65.92 \\
\hline EL SHAARAWY & ROMA & 79 & 0.93 & 65.92 \\
\hline MATTEO POLITANO & SASSUOLO & 69 & 0.92 & 65.91 \\
\hline ALEX & MILAN & 79 & 0.92 & 65.90 \\
\hline ANTONIO DI NATALE & UDINESE & 77 & 0.92 & 65.89 \\
\hline A. FAVILLI & JUVENTUS & 53 & 0.91 & 65.87 \\
\hline MATIAS FERNANDEZ & FIORE & 76 & 0.90 & 65.84 \\
\hline LORENZO TONELLI & EMPOLI & 78 & 0.90 & 65.83 \\
\hline GODFRED DONSAH & BOLOGNA & 73 & 0.89 & 65.78 \\
\hline SEBASTIAN DE MAIO & GENOA & 76 & 0.88 & 65.76 \\
\hline BRUNO PERES & TORINO & 80 & 0.87 & 65.73 \\
\hline ACHRAF LAZAAR & PALERMO & 73 & 0.86 & 65.69 \\
\hline ROBERTO INGLESE & CHIEVO & 70 & 0.86 & 65.68 \\
\hline I.ABATE & MILAN & 77 & 0.85 & 65.65 \\
\hline NICOLAS BURDISSO & GENOA & 76 & 0.84 & 65.62 \\
\hline S.FLOCCARI & BOLOGNA & 73 & 0.83 & 65.58 \\
\hline KEVIN LASAGNA & CARPI & 71 & 0.83 & 65.58 \\
\hline JONATHAN BIABIANY & INTER & 77 & 0.82 & 65.55 \\
\hline \multicolumn{5}{|l|}{ MAXIMILIANO } \\
\hline MORALEZ & ATALANTA & 76 & 0.82 & 65.54 \\
\hline SUSO & GENOA & 75 & 0.81 & 65.52 \\
\hline MAURO ZARATE & FIORE & 76 & 0.81 & 65.52 \\
\hline JASMIN KURTIC & ATALANTA & 74 & 0.81 & 65.51 \\
\hline YUTO NAGATOMO & INTER & 74 & 0.77 & 65.40 \\
\hline ANTONIO DI GAUDIO & CARPI & 72 & 0.77 & 65.38 \\
\hline L.CIGARINI & ATALANTA & 76 & 0.76 & 65.36 \\
\hline ANDREA COSTA & EMPOLI & 74 & 0.75 & 65.31 \\
\hline PERPARIM HETEMAJ & CHIEVO & 75 & 0.70 & 65.15 \\
\hline DIEGO PEROTTI & GENOA & 79 & 0.69 & 65.12 \\
\hline ANDREA MASIELLO & ATALANTA & 73 & 0.68 & 65.08 \\
\hline ANDREA MASIELLO & ATALANTA & 73 & 0.68 & 65.08 \\
\hline NENAD TOMOVIC' & FIORE & 75 & 0.67 & 65.06 \\
\hline ALESSANDRO MATRI & LAZIO & 77 & 0.67 & 65.04 \\
\hline DANIELE BASELLI & TORINO & 78 & 0.66 & 65.01 \\
\hline
\end{tabular}




\begin{tabular}{|c|c|c|c|c|}
\hline DANILO CATALDI & LAZIO & 73 & 0.65 & 64.99 \\
\hline LUCA RIZZO & BOLOGNA & 71 & 0.65 & 64.97 \\
\hline \multicolumn{5}{|l|}{ MARIOS } \\
\hline OIKONOMOU & BOLOGNA & 75 & 0.64 & 64.95 \\
\hline SERGIO PELLISSIER & CHIEVO & 72 & 0.64 & 64.93 \\
\hline VINCENT LAURINI & EMPOLI & 71 & 0.63 & 64.91 \\
\hline ANDREA RISPOLI & PALERMO & 64 & 0.63 & 64.90 \\
\hline MANUEL PASQUAL & FIORE & 72 & 0.62 & 64.89 \\
\hline GERMAN DENIS & ATALANTA & 75 & 0.62 & 64.86 \\
\hline GERMAN DENIS & ATALANTA & 75 & 0.62 & 64.86 \\
\hline SIMONE PEPE & CHIEVO & 76 & 0.62 & 64.86 \\
\hline GAETANO LETIZIA & CARPI & 72 & 0.61 & 64.86 \\
\hline DAVIDE SANTON & INTER & 75 & 0.61 & 64.83 \\
\hline EMILIANO MORETTI & TORINO & 77 & 0.61 & 64.83 \\
\hline FREDY GUARIN & INTER & 79 & 0.58 & 64.75 \\
\hline WESLEY HOEDT & LAZIO & 75 & 0.57 & 64.71 \\
\hline LARANGEIRA DANILO & UDINESE & 76 & 0.57 & 64.71 \\
\hline SERGE GAKPE' & GENOA & 74 & 0.56 & 64.69 \\
\hline MARCEL BUCHEL & EMPOLI & 71 & 0.56 & 64.67 \\
\hline \multicolumn{5}{|l|}{ ALESSANDRO } \\
\hline GAMBERINI & CHIEVO & 77 & 0.55 & 64.65 \\
\hline \multicolumn{5}{|l|}{ MARCO } \\
\hline D'ALESSANDRO & ATALANTA & 69 & 0.52 & 64.55 \\
\hline MARCO BORRIELLO & ATALANTA & 74 & 0.52 & 64.55 \\
\hline A.CERCI & GENOA & 77 & 0.51 & 64.51 \\
\hline \multicolumn{5}{|l|}{ ALEKSANDAR } \\
\hline TRAJKOVSKI & PALERMO & 67 & 0.51 & 64.50 \\
\hline \multicolumn{5}{|l|}{ JAKUB } \\
\hline BLASZCZYKOWSKI & FIORE & 78 & 0.51 & 64.50 \\
\hline DAVID LOPEZ & NAPOLI & 76 & 0.51 & 64.50 \\
\hline A. RUDIGER & ROMA & 76 & 0.50 & 64.46 \\
\hline JERRY MBAKOGU & CARPI & 73 & 0.50 & 64.45 \\
\hline GABRIEL PALETTA & ATALANTA & 77 & 0.49 & 64.44 \\
\hline \multicolumn{5}{|l|}{ ANDREA } \\
\hline BERTOLACCI & MILAN & 76 & 0.49 & 64.43 \\
\hline \multicolumn{5}{|l|}{ ANTONIO FLORO } \\
\hline FLORES & SASSUOLO & 72 & 0.49 & 64.43 \\
\hline IVAN RADOVANOVIC & CHIEVO & 73 & 0.49 & 64.43 \\
\hline MATTIA DE SCIGLIO & MILAN & 75 & 0.48 & 64.40 \\
\hline GIUSEPPE ROSSI & FIORE & 78 & 0.47 & 64.36 \\
\hline DIEGO FALCINELLI & SASSUOLO & 69 & 0.46 & 64.34 \\
\hline SIMONE MISSIROLI & SASSUOLO & 75 & 0.46 & 64.33 \\
\hline BOUKARY DRAME' & ATALANTA & 74 & 0.45 & 64.30 \\
\hline
\end{tabular}




\begin{tabular}{|c|c|c|c|c|}
\hline GERVINHO & ROMA & 80 & 0.43 & 64.24 \\
\hline DOMENICO MAIETTA & BOLOGNA & 73 & 0.43 & 64.24 \\
\hline \multicolumn{5}{|l|}{ LEONARDO } \\
\hline BLANCHARD & FROSINONE & 71 & 0.42 & 64.20 \\
\hline DANIEL PAVLOVIC' & FROSINONE & 65 & 0.41 & 64.16 \\
\hline DUSAN BASTA & LAZIO & 79 & 0.38 & 64.06 \\
\hline EDER & INTER & 79 & 0.38 & 64.05 \\
\hline LUCA PAGANINI & FROSINONE & 65 & 0.38 & 64.05 \\
\hline SILVAN WIDMER & UDINESE & 75 & 0.37 & 64.04 \\
\hline OMAR EL KADDOURI & NAPOLI & 77 & 0.37 & 64.02 \\
\hline MATTEO BRIGHI & BOLOGNA & 70 & 0.35 & 63.95 \\
\hline MAURICIO & LAZIO & 78 & 0.34 & 63.94 \\
\hline \multicolumn{5}{|l|}{ SERGEJ MILINKOVIC- } \\
\hline SAVIC & LAZIO & 75 & 0.34 & 63.92 \\
\hline SINISA ANDELKOVIC & PALERMO & 74 & 0.33 & 63.90 \\
\hline IVAYLO CHOCHEV & PALERMO & 70 & 0.33 & 63.89 \\
\hline \multicolumn{5}{|l|}{ RICCARDO } \\
\hline GAGLIOLO & CARPI & 71 & 0.33 & 63.88 \\
\hline ROBIN QUAISON & PALERMO & 73 & 0.32 & 63.87 \\
\hline \multicolumn{5}{|l|}{ SIMONE } \\
\hline ROMAGNOLI & CARPI & 70 & 0.32 & 63.87 \\
\hline MATO JAJALO & PALERMO & 72 & 0.31 & 63.84 \\
\hline PAOLO SAMMARCO & FROSINONE & 68 & 0.31 & 63.83 \\
\hline MARCO BORRIELLO & CARPI & 74 & 0.30 & 63.80 \\
\hline FELIPE & UDINESE & 73 & 0.30 & 63.77 \\
\hline CRISTIAN ZACCARDO & CARPI & 73 & 0.28 & 63.73 \\
\hline OGENYI ONAZI & LAZIO & 75 & 0.28 & 63.73 \\
\hline LORENZO LOLLO & CARPI & 71 & 0.28 & 63.72 \\
\hline DANIELE CROCE & EMPOLI & 74 & 0.27 & 63.68 \\
\hline DANIELE CROCE & EMPOLI & 74 & 0.27 & 63.68 \\
\hline JUAN JESUS & INTER & 75 & 0.26 & 63.64 \\
\hline ABDOULAY KONKO & LAZIO & 75 & 0.25 & 63.63 \\
\hline LUCA RIGONI & GENOA & 73 & 0.24 & 63.59 \\
\hline \multicolumn{5}{|l|}{ PANAGIOTIS } \\
\hline TACHTSIDIS & GENOA & 74 & 0.24 & 63.57 \\
\hline FRANCESCO LODI & UDINESE & 73 & 0.23 & 63.56 \\
\hline DARIO DAINELLI & CHIEVO & 74 & 0.23 & 63.56 \\
\hline L.PASCIUTI & CARPI & 71 & 0.23 & 63.55 \\
\hline VLAD CHIRICHES & NAPOLI & 76 & 0.20 & 63.44 \\
\hline ALEX FERRARI & BOLOGNA & 67 & 0.20 & 63.44 \\
\hline EDENILSON & UDINESE & 74 & 0.19 & 63.42 \\
\hline RAFFAELE BIANCO & CARPI & 69 & 0.19 & 63.42 \\
\hline
\end{tabular}




\begin{tabular}{|c|c|c|c|c|}
\hline FRANCESCO TOTTI & ROMA & 79 & 0.19 & 63.41 \\
\hline DANIELE DE ROSSI & ROMA & 82 & 0.17 & 63.36 \\
\hline \multicolumn{5}{|l|}{ SANTIAGO } \\
\hline GENTILETTI & LAZIO & 77 & 0.16 & 63.30 \\
\hline AFRIYIE ACQUAH & TORINO & 73 & 0.13 & 63.22 \\
\hline MARIO BALOTELLI & MILAN & 79 & 0.13 & 63.22 \\
\hline EZEQUIEL MUNOZ & GENOA & 72 & 0.13 & 63.21 \\
\hline KAMIL GLIK & TORINO & 82 & 0.11 & 63.15 \\
\hline MARCO BENASSI & TORINO & 75 & 0.11 & 63.15 \\
\hline NICOLAS FREY & CHIEVO & 72 & 0.11 & 63.14 \\
\hline STEFAN RADU & LAZIO & 79 & 0.10 & 63.11 \\
\hline C.IMOOBILE & TORINO & 79 & 0.08 & 63.03 \\
\hline ALJAZ STRUNA & PALERMO & 67 & 0.08 & 63.03 \\
\hline ISAAC COFIE & CARPI & 71 & 0.07 & 63.02 \\
\hline GIUSEPPE VIVES & TORINO & 74 & 0.07 & 63.02 \\
\hline ANTE REBIC' & FIORE & 69 & 0.07 & 63.01 \\
\hline CHRISTIAN ZAPATA & MILAN & 76 & 0.06 & 62.99 \\
\hline SERGIO FLOCCARI & SASSUOLO & 73 & 0.06 & 62.98 \\
\hline \multicolumn{5}{|l|}{ LORENZO } \\
\hline PELLEGRINI & SASSUOLO & 65 & 0.06 & 62.98 \\
\hline OLIVIER NTCHAM & GENOA & 64 & 0.06 & 62.97 \\
\hline MAXI LOPEZ & TORINO & 77 & 0.06 & 62.96 \\
\hline CHRISTIAN MAGGIO & NAPOLI & 75 & 0.04 & 62.89 \\
\hline GORAN PANDEV & GENOA & 74 & 0.03 & 62.88 \\
\hline ALESSIO CERCI & MILAN & 77 & 0.03 & 62.88 \\
\hline A.FLORO FLORES & CHIEVO & 72 & 0.03 & 62.86 \\
\hline IBRAHIMA MBAYE & BOLOGNA & 68 & 0.01 & 62.82 \\
\hline MATTEO MANCOSU & BOLOGNA & 70 & 0.01 & 62.81 \\
\hline ANDREA CONTI & ATALANTA & 67 & 0.00 & 62.79 \\
\hline MARCO ZAMBELLI & EMPOLI & 68 & 0.00 & 62.77 \\
\hline FEDERICO BARBA & EMPOLI & 71 & 0.00 & 62.77 \\
\hline M.BISEVAC & LAZIO & 77 & -0.01 & 62.73 \\
\hline \multicolumn{5}{|l|}{ FABIO } \\
\hline QUAGLIARELLA & TORINO & 78 & -0.03 & 62.68 \\
\hline EDGAR BARRETO & SAMP & 73 & -0.03 & 62.68 \\
\hline MIRKO VALDIFIORI & NAPOLI & 76 & -0.03 & 62.66 \\
\hline IVAN PIRIS & UDINESE & 75 & -0.05 & 62.61 \\
\hline MARKO LIVAJA & EMPOLI & 69 & -0.07 & 62.54 \\
\hline MARTIN MONTOYA & INTER & 78 & -0.07 & 62.53 \\
\hline IVAN STRINIC & NAPOLI & 73 & -0.07 & 62.52 \\
\hline IAGO FALQUE & ROMA & 78 & -0.08 & 62.49 \\
\hline ANDREA RANOCCHIA & INTER & 77 & -0.08 & 62.49 \\
\hline
\end{tabular}




\begin{tabular}{|c|c|c|c|c|}
\hline J.ZUNIGA & BOLOGNA & 72 & -0.08 & 62.49 \\
\hline DANILO SODDIMO & FROSINONE & 68 & -0.11 & 62.40 \\
\hline \multicolumn{5}{|l|}{ GUGLIELMO } \\
\hline STENDARDO & ATALANTA & 74 & -0.12 & 62.36 \\
\hline ERICK PULGAR & BOLOGNA & 68 & -0.14 & 62.31 \\
\hline NICOLO' CHERUBIN & ATALANTA & 72 & -0.14 & 62.28 \\
\hline ISSA CISSOKHO & GENOA & 73 & -0.15 & 62.27 \\
\hline STEFANO MAURI & LAZIO & 79 & -0.15 & 62.26 \\
\hline RICARDO KISHNA & LAZIO & 75 & -0.19 & 62.14 \\
\hline \multicolumn{5}{|l|}{ FABIO } \\
\hline QUAGLIARELLA & SAMP & 78 & -0.19 & 62.12 \\
\hline T. MATAVZ & GENOA & 72 & -0.19 & 62.12 \\
\hline \multicolumn{5}{|l|}{ ROBERT } \\
\hline ACQUAFRESCA & BOLOGNA & 68 & -0.19 & 62.11 \\
\hline CRISTIAN MOLINARO & TORINO & 75 & -0.21 & 62.07 \\
\hline M.WAGUE & UDINESE & 73 & -0.21 & 62.05 \\
\hline ALEANDRO ROSI & FROSINONE & 70 & -0.21 & 62.04 \\
\hline L. DE SILVESTRI & SAMP & 76 & -0.22 & 62.02 \\
\hline G.SILVA & GENOA & 70 & -0.23 & 62.00 \\
\hline \multicolumn{5}{|l|}{ EDOARDO } \\
\hline GOLDANIGA & PALERMO & 70 & -0.23 & 61.98 \\
\hline TINO COSTA & GENOA & 76 & -0.23 & 61.98 \\
\hline GABRIEL SILVA & CARPI & 70 & -0.24 & 61.97 \\
\hline GIANPAOLO BELLINI & ATALANTA & 68 & -0.24 & 61.97 \\
\hline V.REGINI & NAPOLI & 71 & -0.24 & 61.95 \\
\hline GILBERTO & FIORE & 69 & -0.24 & 61.95 \\
\hline J.MENEZ & MILAN & 81 & -0.25 & 61.92 \\
\hline DAVIDE BRIVIO & ATALANTA & 72 & -0.25 & 61.90 \\
\hline ASSANE GNOUKOURI & INTER & 69 & -0.26 & 61.90 \\
\hline HERNANES & INTER & 80 & -0.26 & 61.89 \\
\hline DAVIDE BIONDINI & SASSUOLO & 70 & -0.26 & 61.88 \\
\hline U. $\cos I C$ & EMPOLI & 68 & -0.26 & 61.87 \\
\hline \multicolumn{5}{|l|}{ MICHEL } \\
\hline MORGANELLA & PALERMO & 67 & -0.27 & 61.86 \\
\hline GIAMPIERO PINZI & CHIEVO & 73 & -0.27 & 61.86 \\
\hline N.SPOLLI & CHIEVO & 74 & -0.31 & 61.71 \\
\hline T.COSTA & FIORE & 71 & -0.31 & 61.70 \\
\hline GASTON BRUGMAN & PALERMO & 68 & -0.32 & 61.69 \\
\hline \multicolumn{5}{|l|}{ ARCHIMEDE } \\
\hline MORLEO & BOLOGNA & 70 & -0.32 & 61.68 \\
\hline EROS PISANO & Verona & 72 & -0.32 & 61.67 \\
\hline MAICON & ROMA & 77 & -0.32 & 61.67 \\
\hline A. TABACCHI & BOLOGNA & 67 & -0.34 & 61.63 \\
\hline
\end{tabular}




\begin{tabular}{|c|c|c|c|c|}
\hline MATTIA CASSANI & SAMP & 72 & -0.34 & 61.63 \\
\hline JOAQUIN CORREA & SAMP & 71 & -0.34 & 61.62 \\
\hline LEVAN MCHEDLIDZE & EMPOLI & 71 & -0.35 & 61.59 \\
\hline DIEGO CAPEL & GENOA & 75 & -0.35 & 61.58 \\
\hline MIRKO GORI & FROSINONE & 66 & -0.36 & 61.56 \\
\hline FEDERICO VIVIANI & Verona & 73 & -0.36 & 61.54 \\
\hline \multicolumn{5}{|l|}{ GIOVANNI } \\
\hline MARCHESE & GENOA & 74 & -0.36 & 61.53 \\
\hline MATIAS SILVESTRE & SAMP & 73 & -0.37 & 61.52 \\
\hline S.SABELLI & CARPI & 67 & -0.37 & 61.51 \\
\hline LUCA BITTANTE & EMPOLI & 67 & -0.38 & 61.46 \\
\hline ANDREA POLI & MILAN & 75 & -0.39 & 61.46 \\
\hline A.IONITA & Verona & 74 & -0.39 & 61.44 \\
\hline ENZO MARESCA & PALERMO & 74 & -0.40 & 61.41 \\
\hline K.CONSTANT & BOLOGNA & 71 & -0.41 & 61.39 \\
\hline ALBERTO GRASSI & ATALANTA & 70 & -0.41 & 61.38 \\
\hline LORENZO CRISETIG & BOLOGNA & 71 & -0.41 & 61.36 \\
\hline MARCELLO GAZZOLA & SASSUOLO & 66 & -0.42 & 61.34 \\
\hline M.TROTTA & SASSUOLO & 68 & -0.42 & 61.33 \\
\hline GIAMPAOLO PAZZINI & Verona & 74 & -0.44 & 61.27 \\
\hline ERVIN ZUKANOVIC & SAMP & 71 & -0.45 & 61.25 \\
\hline R. FIAMOZZI & GENOA & 65 & -0.45 & 61.24 \\
\hline P.KONE & FIORE & 75 & -0.46 & 61.20 \\
\hline GENNARO SARDO & CHIEVO & 66 & -0.47 & 61.17 \\
\hline CESARE BOVO & TORINO & 75 & -0.48 & 61.14 \\
\hline DANIELE CROCE & EMPOLI & 74 & -0.48 & 61.13 \\
\hline DANIELE CROCE & EMPOLI & 74 & -0.48 & 61.13 \\
\hline EMIL KRAFTH & BOLOGNA & 67 & -0.49 & 61.10 \\
\hline STIPE PERICA & UDINESE & 70 & -0.49 & 61.10 \\
\hline FILIPPO FALCO & BOLOGNA & 64 & -0.49 & 61.10 \\
\hline RAFFAELE MAIELLO & EMPOLI & 66 & -0.49 & 61.09 \\
\hline \multicolumn{5}{|l|}{ FEDERICO } \\
\hline MATTIELLO & CHIEVO & 71 & -0.51 & 61.03 \\
\hline ROBERTO CRIVELLO & FROSINONE & 67 & -0.51 & 61.03 \\
\hline DODO & SAMP & 73 & -0.52 & 61.01 \\
\hline CRISTIAN RAIMONDI & ATALANTA & 67 & -0.52 & 61.01 \\
\hline G.MONACHELLO & ATALANTA & 66 & -0.52 & 61.00 \\
\hline RAMAN CHIBSAH & FROSINONE & 68 & -0.53 & 60.98 \\
\hline EDSON BRAAFHEID & LAZIO & 72 & -0.53 & 60.98 \\
\hline L.ANTEI & SASSUOLO & 71 & -0.54 & 60.93 \\
\hline MANUEL ITURRA & UDINESE & 74 & -0.54 & 60.92 \\
\hline MATTEO CIOFANI & FROSINONE & 68 & -0.54 & 60.92 \\
\hline
\end{tabular}




\begin{tabular}{|c|c|c|c|c|}
\hline R.FREULER & ATALANTA & 67 & -0.56 & 60.86 \\
\hline $\begin{array}{l}\text { ABDELHAMID EL } \\
\text { KAOUTARI }\end{array}$ & PALERMO & 73 & -0.58 & 60.79 \\
\hline NIKLAS MOISANDER & SAMP & 74 & -0.59 & 60.78 \\
\hline PHILIPPE MEXES & MILAN & 77 & -0.59 & 60.76 \\
\hline THOMAS HEURTAUX & UDINESE & 77 & -0.60 & 60.74 \\
\hline RODRIGO AGUIRRE & UDINESE & 67 & -0.61 & 60.69 \\
\hline Z.KUZMANOVIC & UDINESE & 74 & -0.62 & 60.66 \\
\hline S.GAKPE & ATALANTA & 74 & -0.63 & 60.64 \\
\hline F.ZUCULINI & BOLOGNA & 70 & -0.63 & 60.63 \\
\hline STEFAN DE VRIJ & LAZIO & 81 & -0.64 & 60.59 \\
\hline \multicolumn{5}{|l|}{ NIKOLA } \\
\hline MAKSIMOVIC & TORINO & 80 & -0.64 & 60.58 \\
\hline \multicolumn{5}{|l|}{ DAVIDE } \\
\hline ZAPPACOSTA & TORINO & 76 & -0.64 & 60.58 \\
\hline GERMAN DENIS & ATALANTA & 75 & -0.65 & 60.58 \\
\hline GERMAN DENIS & ATALANTA & 75 & -0.65 & 60.58 \\
\hline KARIM LARIBI & SASSUOLO & 69 & -0.65 & 60.57 \\
\hline SUSO & MILAN & 75 & -0.65 & 60.56 \\
\hline \multicolumn{5}{|l|}{ MICHELE } \\
\hline CAMPORESE & EMPOLI & 67 & -0.66 & 60.53 \\
\hline LUCA RIGONI & PALERMO & 73 & -0.67 & 60.50 \\
\hline GIULIO MIGLIACCIO & ATALANTA & 71 & -0.67 & 60.50 \\
\hline M.MANCOSU & CARPI & 70 & -0.67 & 60.48 \\
\hline S.VERDI & CARPI & 71 & -0.68 & 60.47 \\
\hline EVANGELOS MORAS & Verona & 74 & -0.68 & 60.44 \\
\hline LUCA TONI & Verona & 74 & -0.70 & 60.39 \\
\hline LUCA MARTINELLI & EMPOLI & 63 & -0.70 & 60.38 \\
\hline M.ZAMBELLI & EMPOLI & 68 & -0.71 & 60.35 \\
\hline \multicolumn{5}{|l|}{ EMANUELE } \\
\hline TERRANOVA & SASSUOLO & 70 & -0.72 & 60.33 \\
\hline CARLOS CARMONA & ATALANTA & 74 & -0.72 & 60.31 \\
\hline NIGEL DE JONG & MILAN & 77 & -0.73 & 60.29 \\
\hline K. BOATENG & MILAN & 77 & -0.73 & 60.29 \\
\hline ALESSANDRO FRARA & FROSINONE & 67 & -0.74 & 60.25 \\
\hline JURAJ KUCKA & GENOA & 77 & -0.75 & 60.21 \\
\hline RONALDO & EMPOLI & 62 & -0.76 & 60.20 \\
\hline P.WSZOLEK & Verona & 72 & -0.76 & 60.20 \\
\hline ALEKSANDAR TONEV & FROSINONE & 67 & -0.76 & 60.19 \\
\hline M.CRIMI & CARPI & 66 & -0.77 & 60.16 \\
\hline B.DJIMSITI & ATALANTA & 62 & -0.77 & 60.16 \\
\hline LORENZO ARIAUDO & SASSUOLO & 71 & -0.77 & 60.15 \\
\hline
\end{tabular}




\begin{tabular}{|c|c|c|c|c|}
\hline ROBERT GUCHER & FROSINONE & 70 & -0.77 & 60.14 \\
\hline FRANCO SIGNORELLI & EMPOLI & 68 & -0.79 & 60.08 \\
\hline \multicolumn{5}{|l|}{ ANTONINO LA } \\
\hline GUMINA & PALERMO & 58 & -0.81 & 60.02 \\
\hline N.NINKOVIC & CHIEVO & 68 & -0.81 & 60.01 \\
\hline JUAN ITURBE & ROMA & 77 & -0.81 & 60.01 \\
\hline VASCO REGINI & SAMP & 71 & -0.82 & 59.98 \\
\hline T.CIONEK & PALERMO & 70 & -0.83 & 59.95 \\
\hline SADIQ & ROMA & 63 & -0.83 & 59.93 \\
\hline JOSE' MAURI & MILAN & 72 & -0.85 & 59.89 \\
\hline DAVID IVAN & SAMP & 67 & -0.89 & 59.75 \\
\hline R.ALVAREZ & SAMP & 77 & -0.89 & 59.74 \\
\hline ADRIANO RUSSO & FROSINONE & 67 & -0.93 & 59.61 \\
\hline O.KRAGL & FROSINONE & 66 & -0.93 & 59.61 \\
\hline F.POLI & CARPI & 68 & -0.94 & 59.58 \\
\hline ANTONIO NOCERINO & MILAN & 72 & -0.94 & 59.57 \\
\hline ANDREA RANOCHIA & SAMP & 77 & -0.94 & 59.56 \\
\hline LUCA MARONE & CARPI & 70 & -0.95 & 59.52 \\
\hline \multicolumn{5}{|l|}{ MARCELO } \\
\hline ESTIGARRIBIA & ATALANTA & 73 & -0.96 & 59.51 \\
\hline IGOR BUBNJIC & CARPI & 72 & -0.97 & 59.48 \\
\hline LUIGI GIORGI & ATALANTA & 67 & -0.98 & 59.45 \\
\hline RODRIGO ELY & MILAN & 70 & -0.99 & 59.42 \\
\hline PEDRO PEREIRA & SAMP & 65 & -0.99 & 59.40 \\
\hline SAMUELE LONGO & FROSINONE & 69 & -1.00 & 59.39 \\
\hline PANAGIOTIS KONE & UDINESE & 75 & -1.01 & 59.33 \\
\hline VASSILIS TOROSIDIS & ROMA & 76 & -1.01 & 59.32 \\
\hline FABIO DAPRELA & PALERMO & 67 & -1.02 & 59.31 \\
\hline ROBERTO VITIELLO & PALERMO & 72 & -1.02 & 59.30 \\
\hline R.MARTINHO & CARPI & 72 & -1.03 & 59.27 \\
\hline GASTON SILVA & TORINO & 70 & -1.03 & 59.26 \\
\hline MARQUINHO & UDINESE & 76 & -1.04 & 59.24 \\
\hline E.ZUKANOVIC & ROMA & 74 & -1.04 & 59.22 \\
\hline E.SUAGHER & CARPI & 70 & -1.08 & 59.11 \\
\hline M.DOMIZZI & UDINESE & 73 & -1.09 & 59.06 \\
\hline B.CRISTANTE & PALERMO & 72 & -1.09 & 59.06 \\
\hline \multicolumn{5}{|l|}{ MASSIMILIANO } \\
\hline CARLINI & FROSINONE & 67 & -1.10 & 59.05 \\
\hline GUILHERME & UDINESE & 74 & -1.11 & 58.99 \\
\hline KAMIL WILCZEK & CARPI & 70 & -1.12 & 58.95 \\
\hline MATTEO FEDELE & CARPI & 67 & -1.14 & 58.88 \\
\hline LEANDRO CASTAN & ROMA & 79 & -1.15 & 58.88 \\
\hline
\end{tabular}




\begin{tabular}{|c|c|c|c|c|}
\hline WALLACE & CARPI & 67 & -1.16 & 58.82 \\
\hline ANDREA LAZZARI & CARPI & 72 & -1.17 & 58.81 \\
\hline A.BENTIVEGNA & PALERMO & 57 & -1.17 & 58.80 \\
\hline NICOLAS CASTILLO & FROSINONE & 73 & -1.17 & 58.79 \\
\hline \multicolumn{5}{|l|}{ GIOVANNI } \\
\hline PASQUALE & UDINESE & 69 & -1.20 & 58.70 \\
\hline K.STROOTMAN & ROMA & 80 & -1.20 & 58.70 \\
\hline VICTOR IBARBO & ROMA & 78 & -1.20 & 58.70 \\
\hline ADEM LJAJIC & ROMA & 79 & -1.20 & 58.68 \\
\hline VICTOR IBARBO & ROMA & 78 & -1.20 & 58.68 \\
\hline EMERSON & ROMA & 68 & -1.22 & 58.63 \\
\hline JUANITO GOMEZ & Verona & 73 & -1.22 & 58.62 \\
\hline ALESSANDRO GAZZI & TORINO & 74 & -1.22 & 58.61 \\
\hline MOBIDO DIAKITE & SAMP & 75 & -1.24 & 58.55 \\
\hline DJAMEL MESBAH & SAMP & 71 & -1.25 & 58.51 \\
\hline NICOLAS SPOLLI & CARPI & 74 & -1.26 & 58.48 \\
\hline PONTUS JANSSON & TORINO & 75 & -1.27 & 58.45 \\
\hline DANIELE VERDE & FROSINONE & 69 & -1.28 & 58.43 \\
\hline SALIH UCAN & ROMA & 73 & -1.28 & 58.42 \\
\hline J.DE GUZMAN & CARPI & 76 & -1.30 & 58.35 \\
\hline DANILO AVELAR & TORINO & 75 & -1.30 & 58.35 \\
\hline NENAD KRSTICIC & SAMP & 72 & -1.30 & 58.34 \\
\hline ALEXANDER MERKEL & UDINESE & 68 & -1.31 & 58.32 \\
\hline \multicolumn{5}{|l|}{ FEDERICO } \\
\hline BONAZZOLI & SAMP & 62 & -1.32 & 58.27 \\
\hline \multicolumn{5}{|l|}{ ALEJANDRO } \\
\hline RODRIGUEZ & SAMP & 66 & -1.33 & 58.23 \\
\hline S.LONGO & FROSINONE & 69 & -1.35 & 58.19 \\
\hline F.HELANDER & Verona & 73 & -1.36 & 58.14 \\
\hline DAVIDE BERTONCINI & FROSINONE & 61 & -1.39 & 58.03 \\
\hline LUCA SILIGARDI & Verona & 73 & -1.40 & 58.02 \\
\hline ANGELO PALOMBO & SAMP & 71 & -1.41 & 57.99 \\
\hline F.DAPRELA & CARPI & 67 & -1.44 & 57.87 \\
\hline J.OBI & TORINO & 72 & -1.44 & 57.87 \\
\hline AMAURI & TORINO & 74 & -1.54 & 57.53 \\
\hline A.CODA & SAMP & 70 & -1.56 & 57.48 \\
\hline LEANDRO GRECO & Verona & 72 & -1.57 & 57.44 \\
\hline J.SALA & SAMP & 72 & -1.57 & 57.43 \\
\hline PAWL WSZOLEK & SAMP & 72 & -1.62 & 57.27 \\
\hline MATTEO BIANCHETTI & Verona & 71 & -1.67 & 57.11 \\
\hline L.MARONE & Verona & 70 & -1.75 & 56.82 \\
\hline JACOPO SALA & Verona & 72 & -1.77 & 56.77 \\
\hline
\end{tabular}




\begin{tabular}{|lllll|}
\hline A. FARNERUD & TORINO & 72 & -1.77 & 56.74 \\
\hline $\begin{array}{l}\text { SAMUEL } \\
\text { SOUPRAYEN }\end{array}$ & Verona & 70 & -1.84 & 56.50 \\
\hline EMIL HALLFREDSSON & Verona & 74 & -1.98 & 56.03 \\
\hline BOSKO JANKOVIC & Verona & 73 & -2.23 & 55.18 \\
\hline U.EMANUELSON & Verona & 74 & -2.25 & 55.12 \\
\hline M.FARES & Verona & 65 & -2.29 & 54.98 \\
\hline MICHELANGELO & & & & \\
ALBERTAZZI & Verona & 67 & -2.42 & 54.55 \\
\hline RAFAEL MARQUEZ & Verona & 76 & -2.46 & 54.41 \\
\hline ROMULO & Verona & 73 & -2.49 & 54.29 \\
\hline A.REBIC & Verona & 69 & -2.52 & 54.20 \\
\hline PIERLUIGI GOLLINI & Verona & 70 & -2.58 & 54.01 \\
\hline GILBERTO & Verona & 69 & -2.72 & 53.51 \\
\hline FRANCELINO & & & & \\
MATUZALEM & Verona & 71 & -2.75 & 53.42 \\
\hline D.FURMAN & Verona & 66 & -2.87 & 53.01 \\
\hline
\end{tabular}

The ordinal regression model gives results in the interval $[-2.87,6.82]$. These were linearly transformed to map to scores in the same range, $[53,86]$. as those of FIFA EASports using 3.4 for the slope value and 62.77 for the intercept term. These converted scores were compared to the FIFA EASports scores for each player. The resulting SSE for ORM was 56,444.2, which is substantially higher than that of the Neural Network model4. (the $\mathrm{k}$ value for this ORM model is equal to the number of players that are assessed, i.e., 489)

Paulo Dybala is ranked first amongst all players using Ordinal Logistic Regression model results $($ NNet Score $=84.26$, ORM score $=85.95)$. When viewing this player's rank difference between the two proposed models, we note that it is quite small. Moreover, it should be noted that for many of the top- 
rated players there exists a small difference between the ranks assigned by the two models. It is worth mentioning that the ORM does yield intuitive results. For instance, Dybala can be considered as having had a great season with the most impact of any player for his team by obtaining 19 goals and nine assists. These values gain even greater significance when considering the total number of goals Juventus scored -Dybala's goals make up almost one third of the entire number of goals scored by Juventus during the 2015-16 season. A similar story is conveyed when analyzing the actual performance of Higuain (NNet Score $=86.69$, ORM score $=85.07)$ as he scored 36 goals and two assists.

When analyzing which position each model greatly values, one can see that, for each model, the top 20 players are primarily Strikers. (It should be noted that this type of modelling behavior - that allocates a ranking preference to strikersis similar to other ranking models that have been developed in previous years [31][32] i.e. the more goals you score the better player you are.)

\subsubsection{Comparison of Methods for Scoring and Ranking 5.1.4.1. Repeated measures one-way ANOVA for Comparing Scoring Methods}

The original scoring was from FIFA EASports. They release the scores of all players, every year based on many factors such as their pace, ability to score, 
heading ability, defence, etc.. It must be kept in mind that these scores are heavily based on performance in many previous years.

The SSE for the best Neural Net model was 4908.264. This value is more than ten times smaller than the SSE of 56,444.2 generated from the ORM model. This suggests that Neural Net model4 performs better with regard to duplicating the FIFA scoring of players. One of the reasons may be the fact the ORM is generally used as a ranking model - not a predictive scoring model. The ORM, Neural Net and FIFA scores were further analyzed via a repeated measure One-Way ANOVA.

In this test, the treatments are the three different scoring methods and by using this test we are controlling for the correlation of the scores on the same player.

Table 24:Repeated measures One-Way ANOVA Model

Response transformation matrix

\begin{tabular}{|lrr|}
\hline & scoreFactor1 & \multicolumn{2}{c|}{ scoreFactor2 } \\
\hline Score-orm & -1 & -1 \\
\hline Score-nnet & 0 & 1 \\
\hline Score-ea & 1 & 0 \\
\hline
\end{tabular}

Sum of squares and products for the hypothesis:

\begin{tabular}{|lrr|}
\hline & scoreFactor1 & scoreFactor2 \\
\hline scoreFactor1 & 47893.37 & 47893.67 \\
\hline scoreFactor2 & 47893.67 & 47893.67 \\
\hline
\end{tabular}


Multivariate Tests: scoreFactor

\begin{tabular}{|c|c|c|c|c|c|c|}
\hline & Df & test stat & approx F & num Df & $\begin{array}{l}\text { den } \\
\text { Df }\end{array}$ & $\operatorname{Pr}(>\mathrm{F})$ \\
\hline Pillai & 1 & 0.91629 & 2665.34 & 2 & 487 & $<2.22 \mathrm{e}-16$ \\
\hline Wilks & 1 & 0.08371 & 2665.34 & 2 & 487 & $<2.22 \mathrm{e}-16$ \\
\hline $\begin{array}{l}\text { Hotelling- } \\
\text { Lawley }\end{array}$ & 1 & 10.94595 & 2665.34 & 2 & 487 & $<2.22 \mathrm{e}-16$ \\
\hline Roy & 1 & 10.94595 & 2665.34 & 2 & 487 & $<2.22 \mathrm{e}-16$ \\
\hline
\end{tabular}

Univariate Type III Repeated-Measures ANOVA Assuming Sphericity

\begin{tabular}{|c|c|c|c|c|c|c|}
\hline & Sum Sq & num Df & Error SS & $\begin{array}{l}\text { den } \\
\text { Df }\end{array}$ & F value & $\operatorname{Pr}(>\mathrm{F})$ \\
\hline (Intercept) & 7298708 & 1 & 22454 & 488 & 158623.1 & $<2.2 \mathrm{e}-16$ \\
\hline scoreFactor & 31929 & 2 & 6170 & 976 & 2525.3 & $<2.2 \mathrm{e}-16$ \\
\hline
\end{tabular}

Assuming sphericity holds, we conclude that the three scoring methods are not all the same.

\subsection{Multiple comparisons for Comparing Scoring Methods}

We proceed to use Tukey's HSD test to determine which pairs of scores differ, The results are as follows: 
Table 25:Tukey multiple comparisons of means; 99\% family-wise confidence level

\begin{tabular}{|lrrrrr|}
\hline Scores & \multicolumn{1}{l}{ Difference } & Lwr & \multicolumn{1}{l}{ Upr } & \multicolumn{1}{c|}{ P Adj } \\
\hline NNET-ORM & $9.90 \mathrm{E}+00$ & 9.4270185 & 10.366179 & 0 \\
\hline EA-ORM & $9.90 \mathrm{E}+00$ & 9.4269571 & 10.366118 & 0 \\
\hline EA-NNET & $-6.13 \mathrm{E}-05$ & -0.469642 & 0.469519 & 0.999999 \\
\hline
\end{tabular}

The TukeyHSD results show the pair-wise differences of scores of the three score sets at a 1\% level of significance family-wise. The Difference column provides mean differences. The "Lwr" and "Upr" columns provide lower and upper 99\% confidence bounds, respectively. The "P Adj" column shows the pvalues adjusted for the number of comparisons made. As there are three sets of scores, three possible pair-wise comparisons are obtained. The results show that NNET and EASports(FIFA) do not give significantly different results but that ORM results differ significantly from both of NNET and EASports (FIFA).

Recall that we must assess the sphericity assumption of the fitted models. When checking the sphericity, the Mauchly test was applied to the three sets of scores.

Table 26:Mauchly test for sphericity

\begin{tabular}{|lrl|}
\hline & Test Statistic & $p$-value \\
\hline ScoreFactor & 0.75221 & $7.7334 \mathrm{e}-31$ \\
\hline
\end{tabular}

Based on these results in Table 26, the assumption of sphericity is invalid and hence the use of the parametric ANOVA and Tukey's HSD is not supported. 


\subsubsection{Multiple Comparisons of Scoring Methods}

Given the results above, a multiple comparison analysis was performed to assess for pairwise differences in the model scores. Multiple pairwisecomparison testing using the Wilcoxon signed-rank test was performed. The null hypothesis for the Wilcoxon signed-rank test is that the median difference between pairs of observations is zero. Note that this is different from the null hypothesis of the parametric paired t-test, which is that the mean difference between pairs is zero. For each of the pairwise groups, we find that the Wilcoxon signed-rank test using Benjamini and Hochberg [30] (BH) yields results that allow the null hypothesis to be rejected for the EA vs. ORM and the NNETModel4 vs. ORM comparisons. Thus we conclude that ORM differs from EASports and NNETModel4 but that NNETModel4 and EA are not significantly different.

\footnotetext{
Table 27:Pairwise comparisons using Wilcoxon rank sum test ${ }^{*} p$-value adjustment method: $\mathrm{BH}$
}

\begin{tabular}{|lcc|}
\hline Column1 & EASports & NNET \\
\hline NNET & 0.36 & \\
\hline ORM & $<2 \mathrm{e}-16$ & $<2 \mathrm{e}-16$ \\
\hline
\end{tabular}




\subsection{Spearman's rank correlation}

Using FIFA EASports, NNETModel4, and the ORM scores, the players were ranked and the three sets of ranks were examined for correlation. The Spearman Correlation test yields results that indicate that, in each pairwise case, the null hypothesis is rejected at a type I error level of .01, where the null hypothesis is that there is no correlation between ranking methods. Hence, there exists evidence that suggests the models' ranks are correlated. It also should be noted that the values for the Spearman Correlation coefficients are .593 for the EA - ORM pair, .699 for the EA - NNET Model4 pair, and .843158 for the NNET Model4 - ORM pair.

\subsection{Inter-Relater Reliability Analysis}

Performing an Inter-Relater Reliability (IRR) analysis using the "irr" package in $\mathrm{R}$ on the pairwise combinations of the model scores' rankings with Cohen's Kappa statistic

$$
\kappa=\frac{p_{o}-p_{e}}{1-p_{e}}=1-\frac{1-p_{o}}{1-p_{e}}
$$

where:

$$
p_{o}=\text { the relative observed agreement among raters. }
$$


$p_{e}=$ the hypothetical probability of chance agreement

yields result that suggest that when comparing the three ranking methods, the highest similarity (the Kappa measure) is between NNET Model4 and EASports rankings and also the ORM and NNET Model4 are more similar than ORM and EA rankings.

The results are as follows:

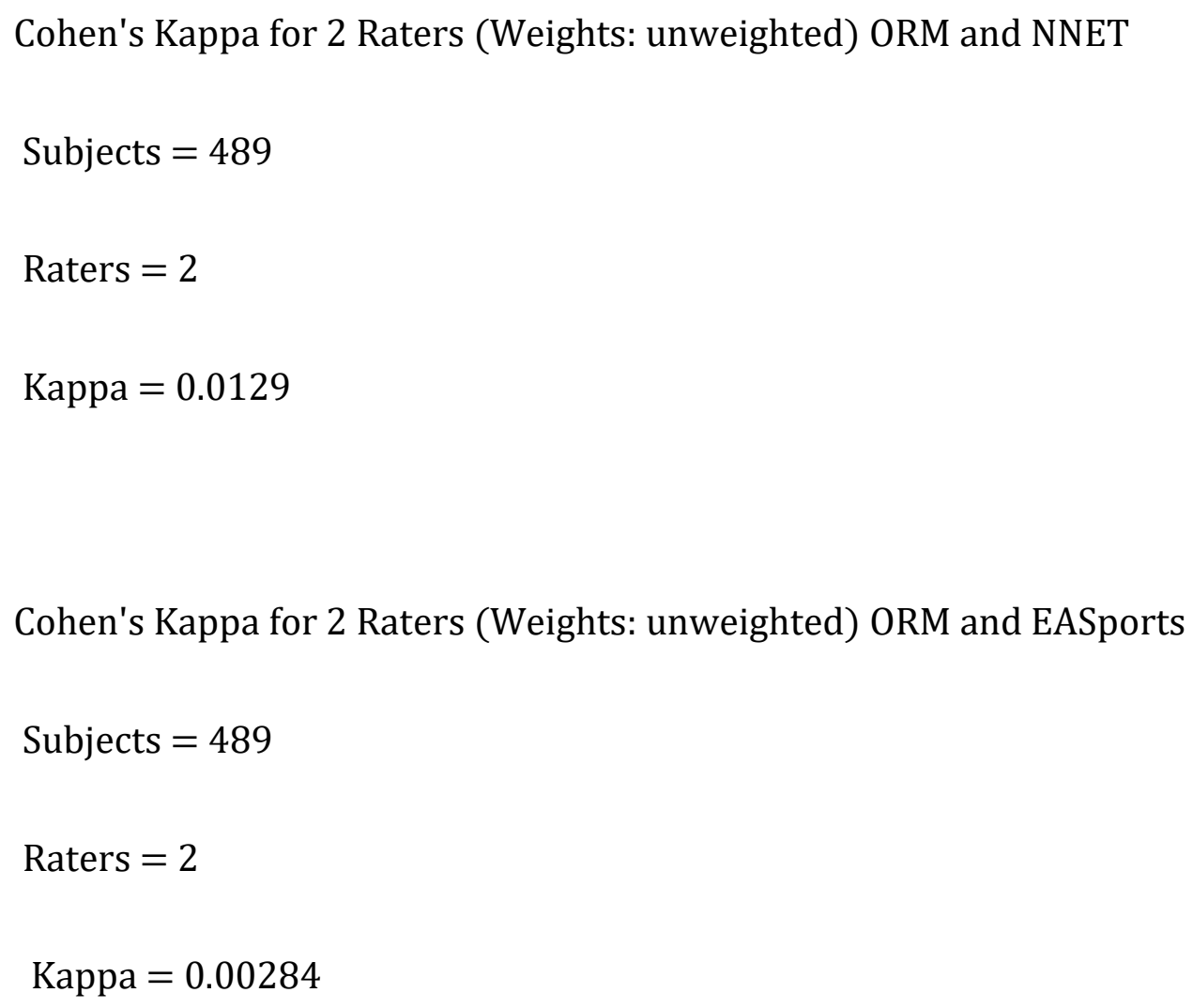


Cohen's Kappa for 2 Raters (Weights: unweighted) NNET and EASports

Subjects $=489$

Raters $=2$

Kappa $=0.0114$

\subsubsection{Summary of ORM/NNET Findings}

Given the results above, it appears that NNET Model4 is better at generating players' scores similar to those from EA Sports. NNET Model4 had a substantially lower SSE than ORM. ORM seems to produce, on average, lower scores than NNET Model4 whereas NNET Model4 yields results that are almost identical to the EA Sports' scores. It should also be noted that the number of explanatory variables utilized in both the NNET Model4 and ORM are rather few and simplistic in some sense. 


\subsection{Association rule mining}

In this section, the purpose was to suggest a methodology to address the second objective of the thesis - to find a player or group of players who had the greatest impact on a team winning (or not winning) a match. Since data from all of the teams could produce a vast number of rules, only the champions for the 201516 season (Juventus) were considered for discussion to address objective 2 of this thesis.

Each team has 10 players on the field (not including the goalkeeper) at the same time. If they used all three substitutes during the match, at most 13 players could play on a team in any one match. To consider a rule as beneficial, the lift associated with a rule must be higher than 1 . We consider the resulting rules and examine their interpretations.

\subsubsection{Data preparation}

To do association rule mining, we needed to create a binary matrix and then employ the apriori function in the AruleViz package in R. For the matrix, the columns represented players and each row represented a game. There were a few players that played only one or two matches the entire season and were sold to other teams; they were removed from the data set since including them 
resulted in many non-useful rules. This reduced the number of players in the analysis to 25 .

The data set was divided into a submatrix for each team; that submatrix contained information on all games played by that team, home and away. Only the champions of the $2015-16$ season are written-up in this thesis.

We examined which players fell within the rules most often in games that the team won and which players were playing (or not playing) when the team lost. Various values for support and confidence were used in performing these analyses but, for the sake of illustration, only some of the results are provided in this thesis.

These derived rules have direct interpretation and can be used to help identify players that provide the team with a high level of performance. Moreover, further inference can be drawn from these rules with respect to determining how important each player's position is for a specific matchup between two teams. Players work as a team in soccer and hence some can produce opportunities that lead to goals for other players. In some cases, a player may be good at destroying the opponent's in-game tactics and hindering them from playing their usual system. 


\subsubsection{Results: Association rule mining}

We now consider the association rule mining results. The purpose was to demonstrate a methodology that would find the best player(s) in terms of winning games. We also are interested in detecting players associated with games that were not won. For purposes of this write-up we considered only the Juventus team.

Table 24 below shows the rules for winning games and Table 25 shows the rules for losing games. The tables were sorted by lift from the maximum to minimum.

We transformed the data into transactional data format and in this section we consider only games played by Juventus. A column was added to delineate if the match was won using:

$$
\left\{\begin{array}{l}
\text { if } \operatorname{win}=1 \quad \text { match was won } \\
\text { if } \operatorname{win}=0
\end{array}\right.
$$

We used the apriori function from the AruleViz package in R. In the apriori function we can define a right-hand side (rhs) as the event for which we wish rules. Thus, setting $r h s$ to be win=1 finds rules for winning matches. We can repeat a similar procedure to obtain rules for matches that result in a loss or a tie.

In this analysis only the players on one team were considered, since the data that was available was too little and it was not possible to find out if a player is performing better (or worst) against a certain team. 


\subsubsection{Rules for winning}

Below we examine the top 10 rules for a win for Juventus (support $\geq$

0.6 and confidence $\geq 0.7$ ). In examining rules, we used various levels for support and confidence.

For when $r h s=$ " win=1", rules sorted in order of lift are:

Table 28:Top rules for Juventus winning

\begin{tabular}{|c|c|c|c|c|c|}
\hline Ihs & rhs & Support & Confidence & lift & count \\
\hline$\{$ A. BARZAGLI=1\} & $\{$ win $=1\}$ & 0.625 & 0.8064516 & 1.112347 & 25 \\
\hline$\{P$. DYBALA $=1$, A. MORATA=1 $\}$ & $\{$ win $=1\}$ & 0.6 & 0.8 & 1.103448 & 24 \\
\hline $\begin{array}{l}\{\text { L. BONUCCI=1, P. DYBALA }=1, A . \\
\text { MORATA }=1\}\end{array}$ & $\{$ win $=1\}$ & 0.6 & 0.8 & 1.103448 & 24 \\
\hline$\{$ A. MORATA $=1\}$ & $\{$ win $=1\}$ & 0.675 & 0.7941176 & 1.095335 & 27 \\
\hline$\{P . P O G B A=1, A . M O R A T A=1\}$ & $\{$ win $=1\}$ & 0.625 & 0.78125 & 1.077586 & 25 \\
\hline$\{$ L. BONUCCI=1, A. MORATA=1\} & $\{$ win $=1\}$ & 0.625 & 0.78125 & 1.077586 & 25 \\
\hline$\{P . D Y B A L A=1\}$ & $\{$ win $=1\}$ & 0.65 & 0.7647059 & 1.054767 & 26 \\
\hline$\{$ L. BONUCCI=1, P. DYBALA=1\} & $\{$ win $=1\}$ & 0.65 & 0.7647059 & 1.054767 & 26 \\
\hline$\{$ L. BONUCCI=1 $\}$ & $\{$ win $=1\}$ & 0.675 & 0.75 & 1.034483 & 27 \\
\hline$\{P . P O G B A=1\}$ & $\{$ win $=1\}$ & 0.65 & 0.7428571 & 1.024631 & 26 \\
\hline$\{$ L. BONUCCI=1, P. POGBA $=1\}$ & $\{$ win $=1\}$ & 0.6 & 0.7272727 & 1.003135 & 24 \\
\hline
\end{tabular}

The highest lift belongs to A. Barzagli playing in a match - a lift of $111.2347 \%$. A rule that has a lift equal to 1.1123indicates that the chance of winning a game will increased by $11 \%$, using that combination of players.. Support is an indication of how frequently the items (i.e. player or group of players) appear in the data. Moreover, confidence shows the proportion of times the condition (e.g. winning) has occurred, given that player or group of players. Barzagli is a 
defender, nicknamed "The Wall" because he is a strong defender and opponents have problems passing through him. He is known to be fast [31] and he can clear crosses and also, he is a good tackler, which helps him to get the ball back or clear a dangerous attempt.

It must also be mentioned that a $10 \%$ increase in the chance of winning a soccer match is very significant and it can impact whether a team wins the championship at the end of the season. You can follow Barzagli's performance in the Figure 11:

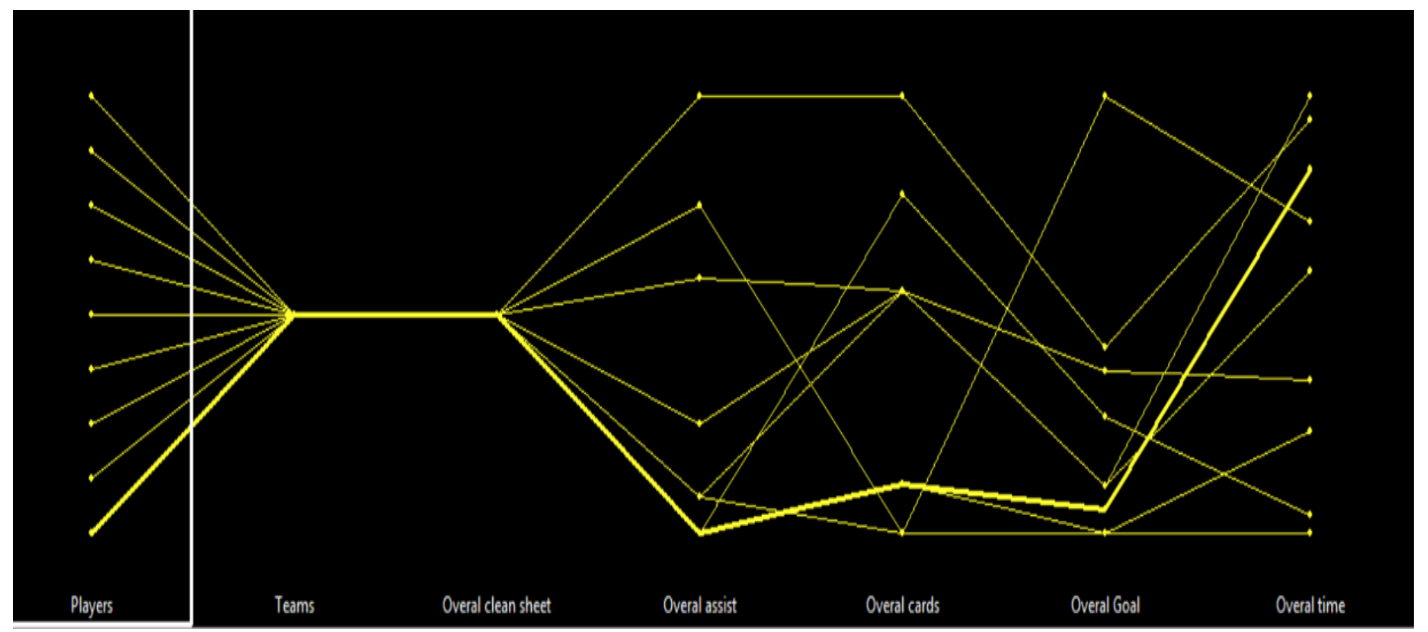

Figure 13: Overall performance of A. Barzagli

The next group of rules, Rules 2-6, all involve A. Morata playing in a match. He was usually one of the two strikers in the 3-5-2 formation [33][34] or playing as a substitute for Mario Mandzukic.

The second highest lift (110.3448\%) is associated with Dybala and A. Morata playing together in a match. This lift means having these two players play 
together results in a $10 \%$ increase in the chance of winning a match. They are both strikers. Dybala's playing style has more dribbling, winning one-on-one challenges, and creating spaces for other strikers; Morata is more of a striker who needs space to score goals. This rule indicates these two players have a good understanding of each other's movement and playing style since both are among the top assist's players on the team. In total, in 2015-16 they created 16 goals (assists) and scored 26 goals.

The third rule, with the same lift as the second rule above, adds L. Bonucci to the pairing of P. Dybala and A. Morata. L. Bonucci was one of the best defenders in the 2015-16 season [35]. Also, because of his passing accuracy and ability to make plays from the defense line, he was a valuable player in the squad and works well with the Dybala/Morata pairing. However, having Bonucci paired with the other two does not change the chance of winning.

Rule 4, with a lift of $109.5335 \%$, quantifies the effect of Morata alone on a match win. Morata by himself can increase the chance of winning by $9.5 \%$ but when he is paired with Bonucci or Pogba in the other rules, the lift decreases.

Rules 5 and 6 have the same lift - 107.7586\% - and both involve pairing Morata with either P. Pogba or L. Bonucci. Pogba is the only Midfielder that appears in these top 10 rules. He had the most assists in the 2015-16 season (12 assists) and, among midfielders, was the top scorer with 8 goals. He was sold to Manchester United the following season for the record signing (at the time) of€ $105 \mathrm{M}$. 
If we go further, in the last three rules, the rules are Bonucci and Pogba alone and a combination of two of them. It can be observed that the combination of the two players would decrease lift and therefore, the chance of winning a match. Now let us consider further the players that appear in these rules.

A. Barzagli is a defender who played 2877 minutes in the season, making him the third highest in the timetable for the Juventus squad. He received only two yellow cards and scored once during the 2015-16 season. One of his strong abilities is that he is a solid defender that any Goalkeeper can rely on. His tackles are clean - he received only two yellow cards during the entire season and he is one of best players who can clear balls in the air (high balls). This ability can be useful for the set pieces which are mostly crossed balls which are high.

L. Bonucci is considered as one of the best defenders in the world from the critics' point of view. One of his abilities is making successful long passes during matches and he has one of the highest passing accuracy rates among all players in the five major leagues in Europe. (Premier League, La Liga, BundesLiga, Serie A, League One). With his ability a team can plan to start their strategy from the back lines and go deep gradually and, if the opposing team is pressuring to get the ball back with their strikers, he can make long passes to relieve the pressure from the back line and help the team to play according to their game plan and 
force their game plan on their opponent. Therefore, he can be a treasure to any coach and having him in the squad cannot be anything but beneficial. He is a good player who has been playing regularly - he was one of the top players in the time on the field table (Table 1) with 3325 minutes out of 3420 minutes in 38 games during the season (without counting injury times).

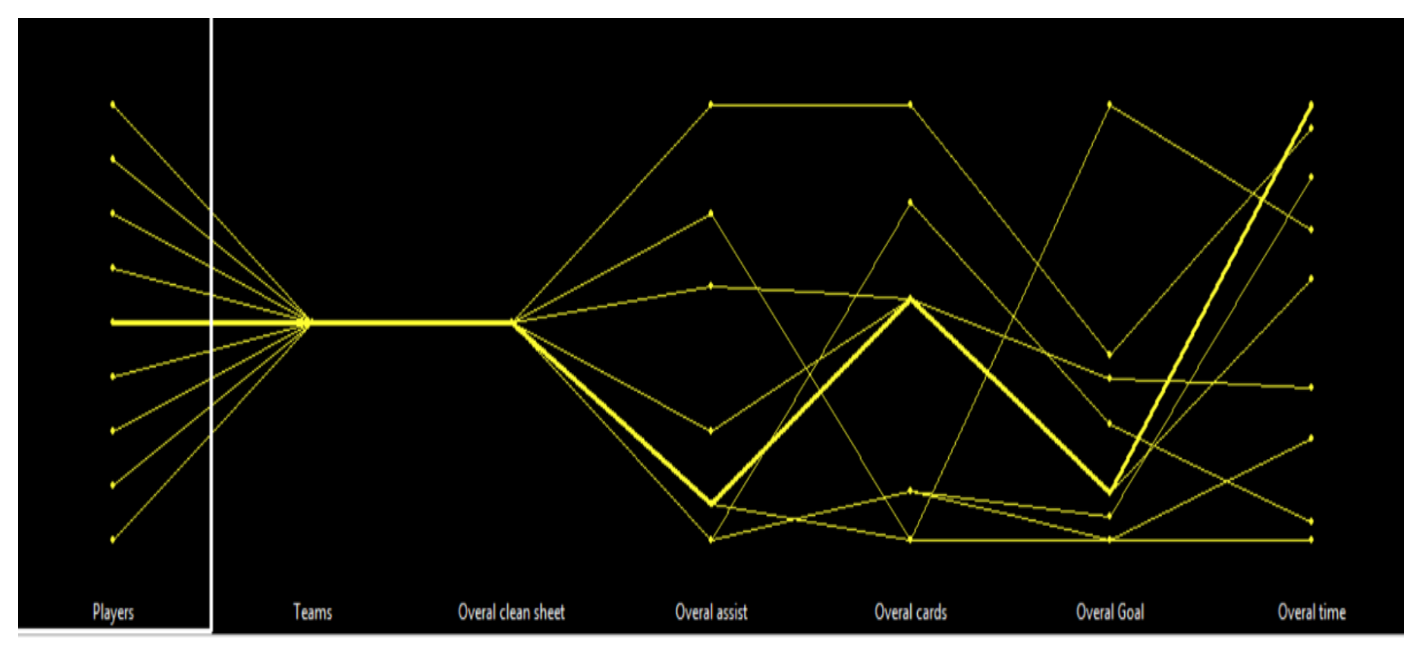

Figure 14: Overall performance of L.Bonucci

He had only six yellow cards, one assist, and 2 goals during the season.

Additionally, Juventus made 22 clean sheets during the season, which is a Serie A Record for the most clean sheets in one season [36].

P. Pogba is the second player on the time table for the Juventus squad in the 2015-16season. He is young and promising player; in the 2015-16 season he was only 22 years old. He made 12 assists (highest number of assists that season) and scored eight goals which, for a Midfielder, is consider high. P. Pogba 
can be considered a regular player for the squad but it should also be mentioned that he was sold at the end of the season to Manchester United- one of the top teams in the Premier League- for the record signing of $105 \mathrm{M}$ symbo; $€$, which made him the most expensive player of all time in the pre-season of 2016-2017.

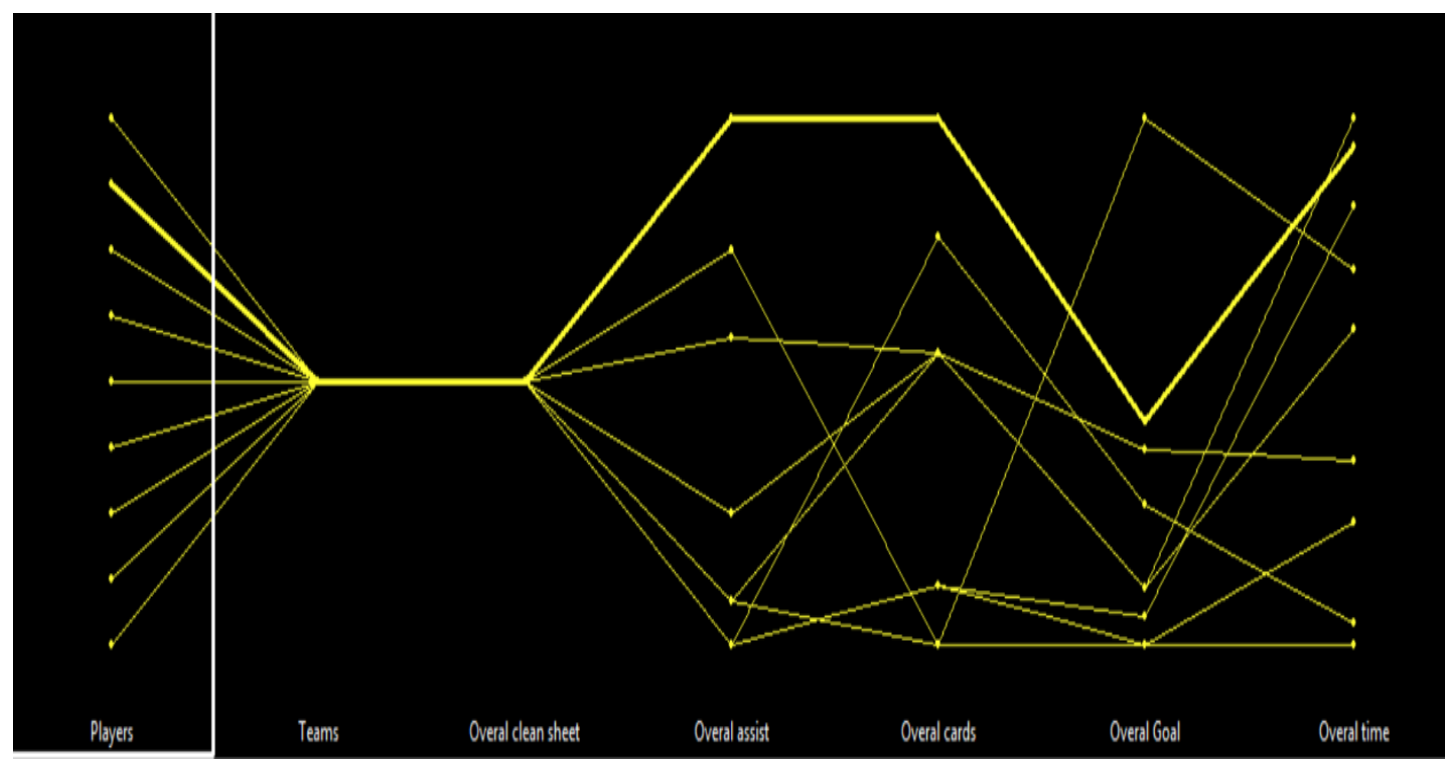

Figure 15: Overall performance of P. Pogba

P. Dybala was bought for this 2015-16 season as a young star Striker who had good dribbling abilities and was good at scoring. This season was his first season playing with the squad. He played 2547 minutes in that season - 4th highest play time - and scored 19 goals - the highest scorer for Juventus in that season. 


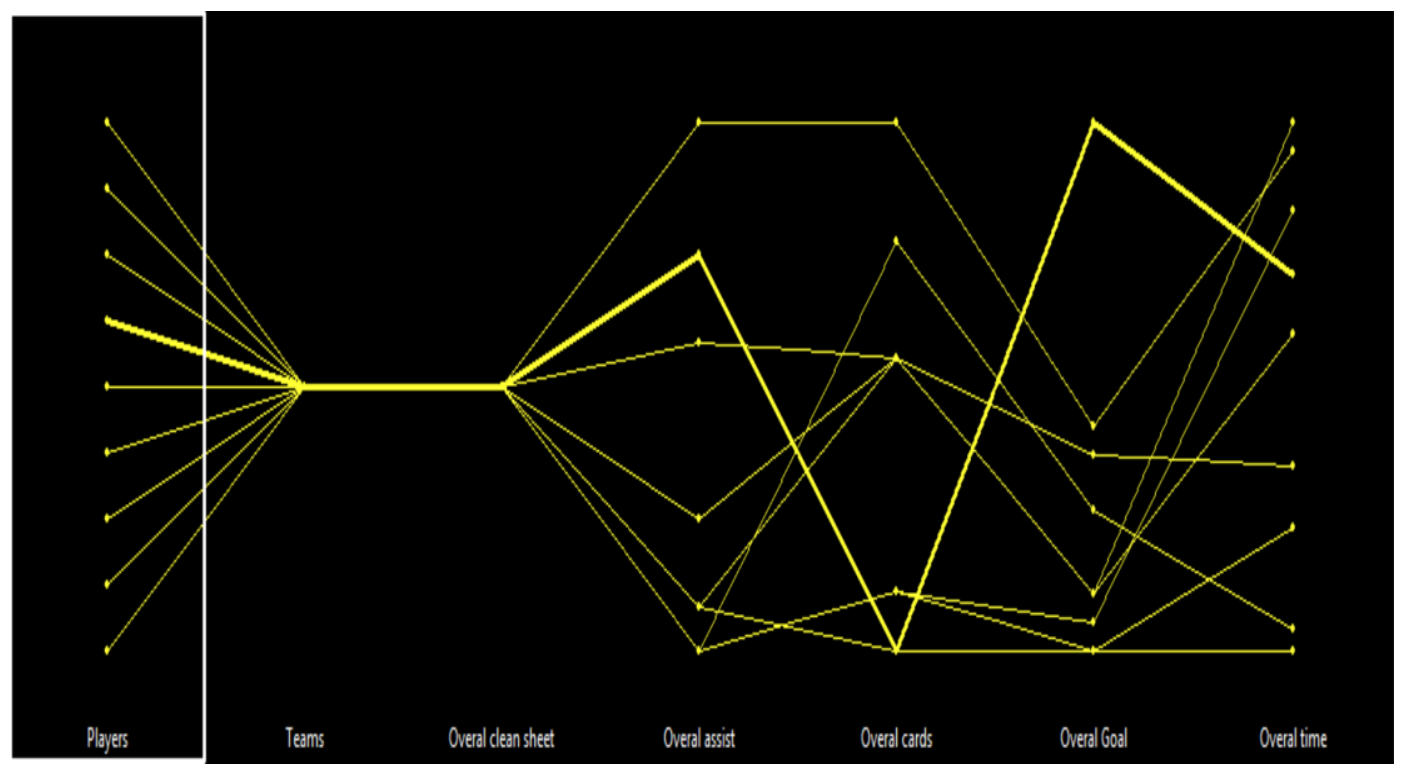

Figure 16: Overall performance of P. Dybala

A. Morata is another young Striker in the Juventus squad. He was usually played as a substitute but, because of his abilities and his pace, he had potential to be a game-changer in most of the games. He scored seven times in the season and had seven assists and six yellow cards. Although he only played 1554 minutes in the entire season, he stood $4^{\text {th }}$ in the squad in the Overall scores table and $3^{\text {rd }}$ in total number of assists. 


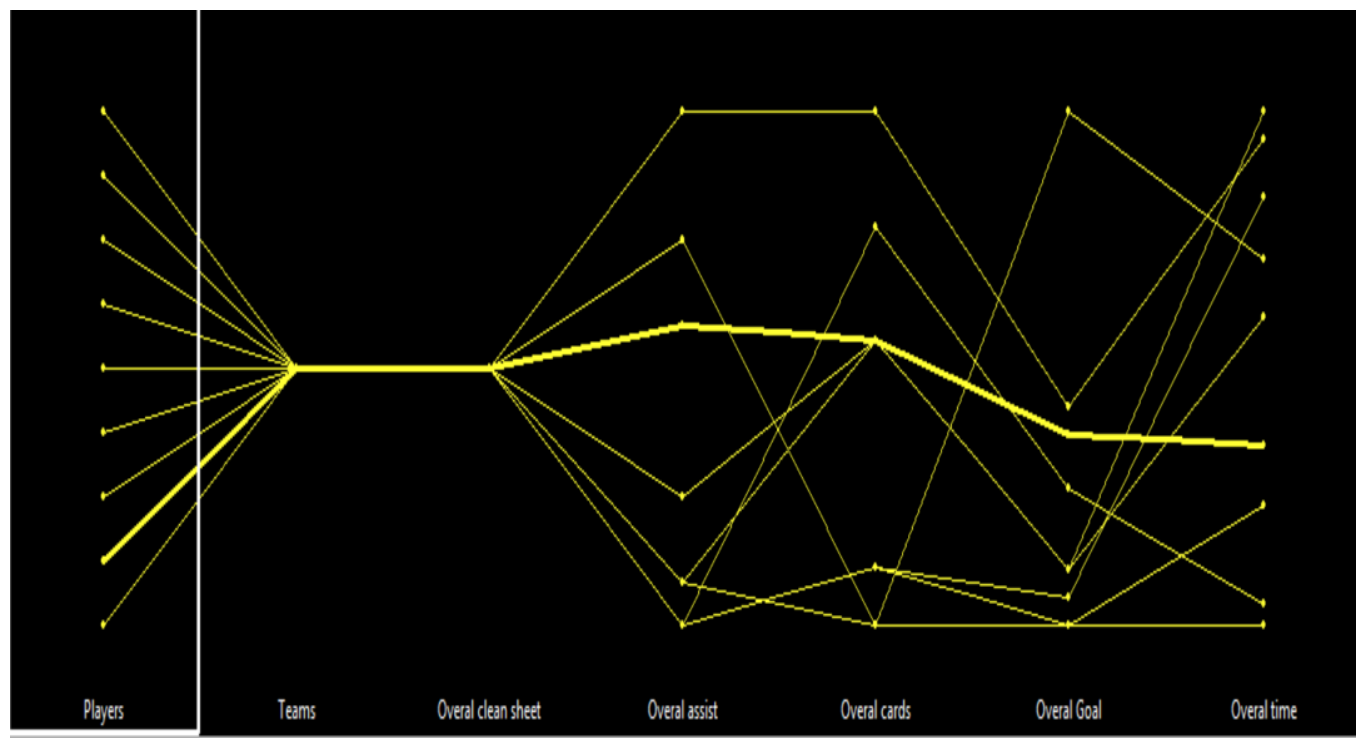

Figure 17: Overall performance of A.Morata 


\subsubsection{Rules for Losses or Ties:}

Using " win $=0$ " (lost or tied matches) with support $\geq 0.2$ and confidence $\geq 0.6$ gives the following top rules for Juventus, by lifts:

Table 29:Top rules for Juventus not winning

\begin{tabular}{|c|c|c|c|c|c|}
\hline Ihs & rhs & Support & Confidence & lift & Count \\
\hline$\{C L A U D I O$ MARCHISIO=0, SAMI KHEDIRA=0 $\}$ & $\{$ win $=0\}$ & 0.2 & 0.72 & 2.64 & 8 \\
\hline $\begin{array}{l}\{S A M I \text { KHEDIRA }=0, K W A D W O \text { ASAMOAH=0, } \\
\text { DANIELE RUGANI }=0\}\end{array}$ & $\{$ win $=0\}$ & 0.225 & 0.69 & 2.51 & 9 \\
\hline$\{S A M I K H E D I R A=0$, DANIELE RUGANI $=0\}$ & $\{w i n=0\}$ & 0.225 & 0.64 & 2.33 & 9 \\
\hline$\{$ SAMI KHEDIRA=0, KWADWO ASAMOAH=0 $\}$ & $\{$ win $=0\}$ & 0.225 & 0.6 & 2.18 & 9 \\
\hline
\end{tabular}

Due to the small number of games that Juventus did not win that season, we obtain only four rules. The first rule indicates that if two of the best midfielders (Marchiso and Khedira) are not playing, the lift=264\%, meaning the chance of not winning the game increases by $164 \%$. This suggests that the rest of the midfielders of Juventus simply are not able to cover those positions.

The next three rules with highest lift all involve Khedira not playing and, in all three cases, the lift exceeds 2 , meaning at least a doubling of the chance of not winning a game if he is not playing.

In the second highest lift rule, there are two other players (Asamoah and Rugani) whose absence from play is strongly associated with the team not winning a match. The first player is Kwadwo Asamoah. He usually plays on the left wingback. He was injured most of the $2015-16$ season so his playing time was 
low compared to other players in his position. The other players who could play in his position were Alex Sandro and Patrice Evra. Alex Sandro was usually playing forward wing because Juventus did not have enough players for that position. As a matter of fact he was the only player who could fit in that position because he is left-footed and has good dribbling ability and his crosses have high accuracy. Therefore, he was played as left winger more than left back winger. Hence, the only real option for the coach was Patric Evra. Even though he was an experienced defender, since he was over 30 years old, he did not perform well for the entire season. The last other player in Rule 2 was Danile Rugani. At the time of his purchase, he was a young promising defender and he was considered heir to Barzagli who was near the end of his career and needed more rest time for recovery. For more clarity, Rugani was new on the squad and the approach of the head coach for young and new players is to wait until they are synched with the team and the playing style and then the coach brings them into the squad slowly by letting the young players play in less important matches. It can be concluded that by letting them play in those matches, they gain experience in a real match and also, they can learn from other players. (Examples of players introduced in this way are Bonucci or Barzagli.) Therefore, it is hard to conclude he was irreplaceable player or that his presence was crucial for the team to win even though, whenever he was playing, Juventus was on the winning side.

Applying apriori can help us find players that are synched together and have a good understanding of each other's game play and game style as well as finding 
crucial players for the squad i.e. players who can help the team to win their matches.

Now we examine further the players mentioned in these rules.

Kwadwo Asamoah is a left wing back. He only played 609 minutes in the entire season. (In that season he had a knee injury that took a long time for recovery.) He had one assist and received one yellow card. The rules suggest that whenever he was not playing there was at least a doubling of the chance the team did not win. One of his characteristics is that he does not do show-offs like dribbling or similar things; he is a team player.

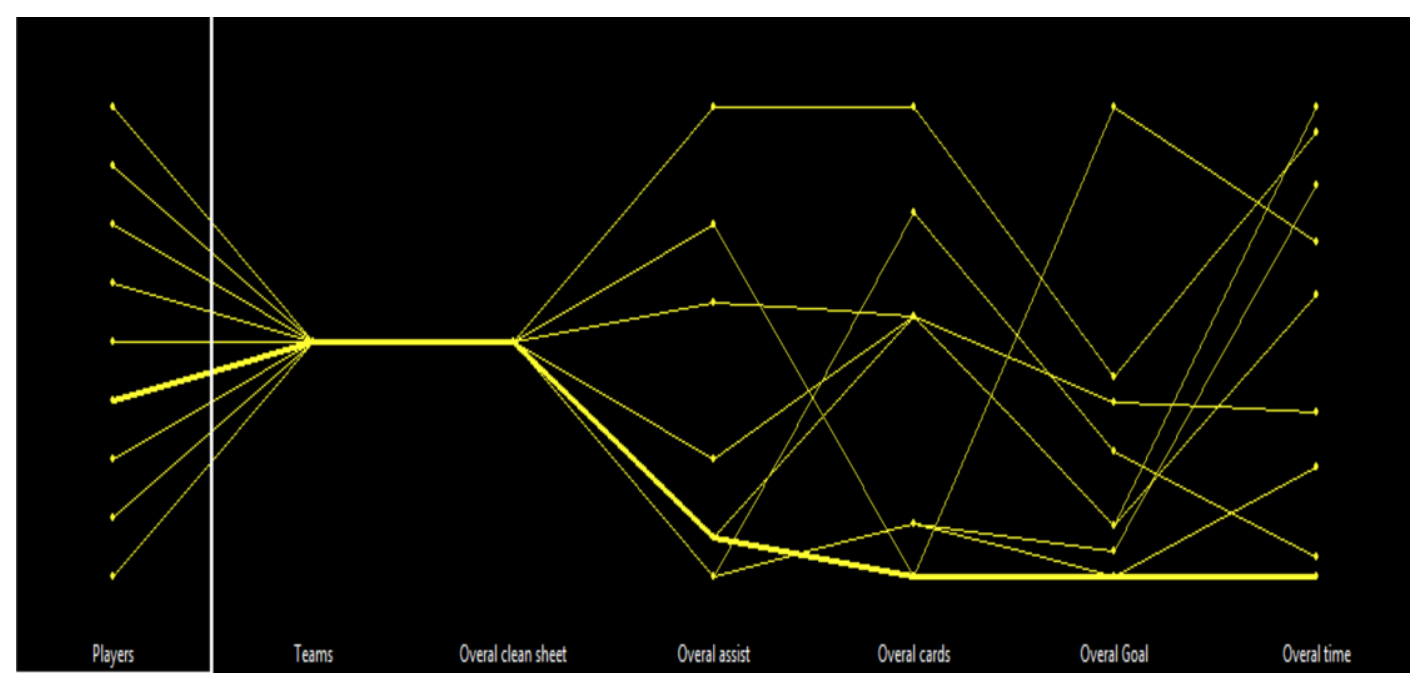

Figure 18: Overall performance of $K$. Asamoah

D. Rugani is a Central Defender. In the previous season as a Defender he did not receive a single warning card. Even though he was only 21 years old, he showed maturity in his game style. He was bought as a starlet, and since he has just joined the squad, he needs time to get used to the game style of the team and to synch 
with other players. As a consequence he did not play many games as a regular at the beginning of the season. He played a total of 1242 minutes and only received two yellow cards and did not score or assist. However his not playing is strongly associated with Juventus not winning the match- more than a doubling of the probability of losing.

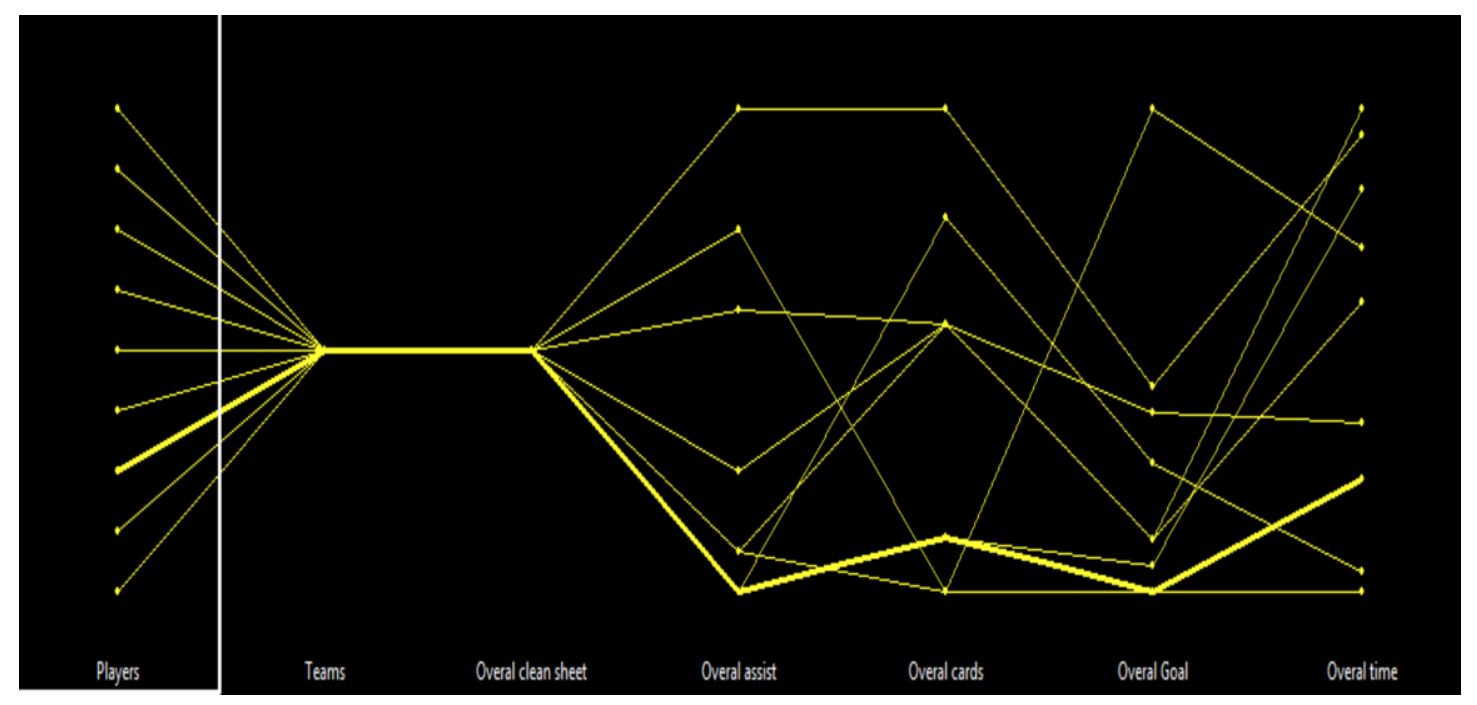

Figure 19: Overall performance of D. Rugani

Claudio Marchisio accrued 2030 minutes of game play in the 2015-2016 season, ranking him among the top ten players in terms of highest amount of game play. One should note that he did not score any goals in this large amount of playing time and only incurred two assists. This is perhaps due to his playing style, in conjunction with his position as a midfielder, which is mostly concerned with connecting the defensive line to the attacking line. We see that when Marchisio and Khedira were not playing, there is an increase of $164 \%$ in the probability of Juventus losing. 


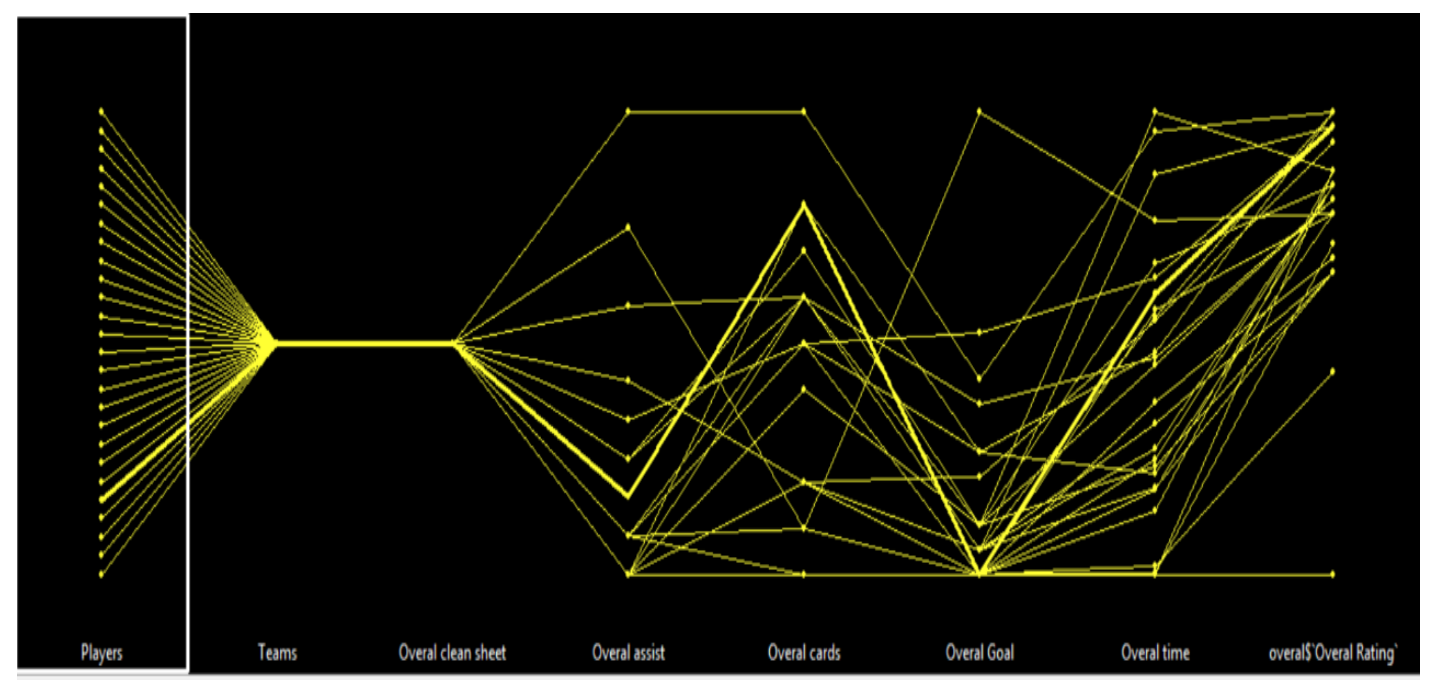

Figure 20: Overall performance of Claudio Marchisio

Another noteworthy midfielder is Sami Khedira who scored 5 goals and assisted 4 times. One of Khedira's primary duties is to help the attackers when they are applying pressure in regards to scoring a goal. Another duty Khedira takes on is helping relieve the pressure being applied by opposing teams to his team's defense.

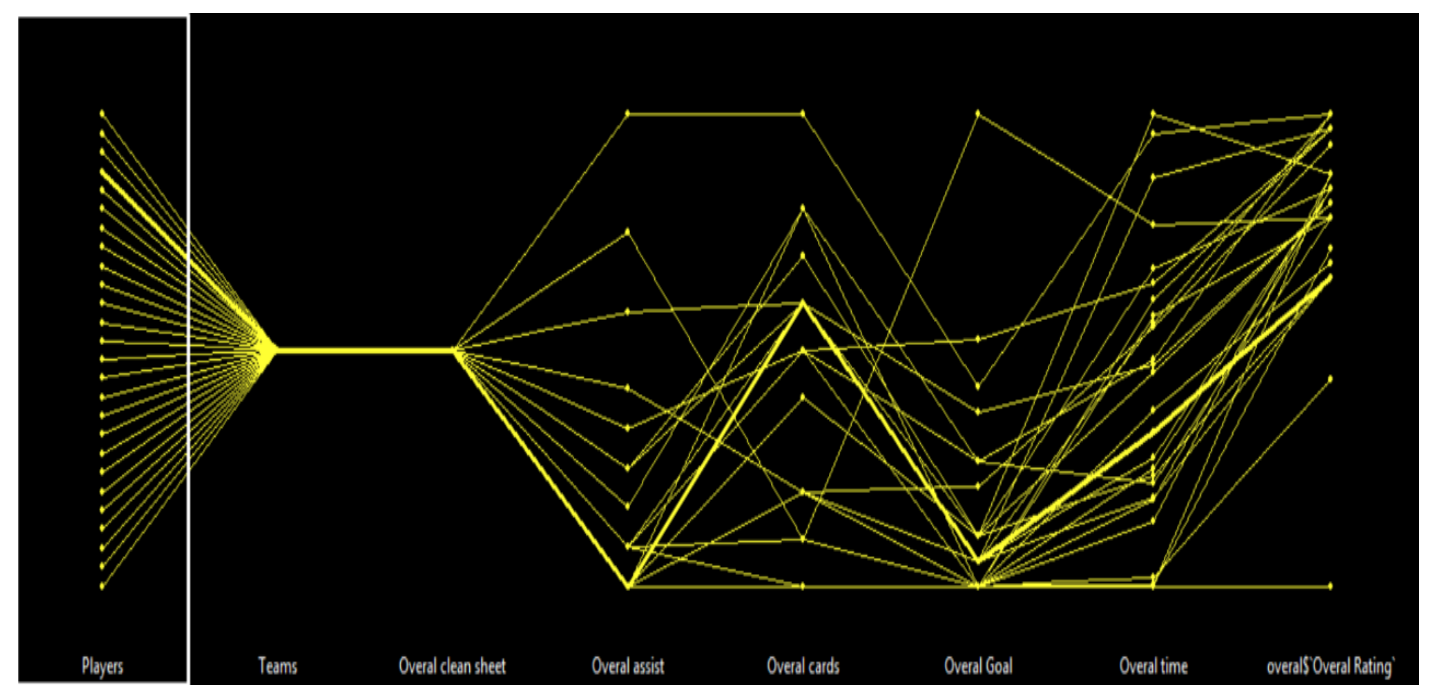

Figure 21:Overall performance of Sami Khedira 


\section{Conclusions}

This thesis explicitly considered the following questions:

1.) Can we duplicate the FIFA rankings from EA Sports' 2015-16 players' rankings?

2.) Can we find a methodology that provides insight into players or combinations of players that increase the chance of a team winning a match? Similarly, can we find a methodology that identifies players or combinations of players that decrease the chance of a team winning a match?

The research performed within this thesis was organized into three segments:

1. Data gathering and manipulation

2- Neural Network and Ordinal Regression Modelling of player scoring and comparison with EASport's FIFA scoring and ranking

3-Association Rule Mining for finding rules for winning (losing) team play

The most time-consuming part of this research involved data wrangling. However, as stated in the introduction, this was initially anticipated since in much applied research, data preparation is notorious for being a timeconsuming endeavour. Moreover, in this particular situation, a variety of different modelling techniques and approaches required that the data be brought into alternate forms in order to conduct the analyses. 
To address the first problem of duplicating the FIFA EASports' scoring of players, we employed two methods- neural networks and ordinal logistic regression. Both methods were used to score and subsequently rank players. We note that we had only data for 2015-16 but that FIFA EASports' scoring of players is based on years of historical data. Even so, we were able to obtain a fairly realistic scoring method using Neural Network modelling. In the case of ordinal logistic regression, initially the model generated a latent variable score for the players and then a linear transformation was implemented to map these to player scores. The results of both methods were compared against FIFA EASports scoring. From our results, it is apparent that, as far as replicating the FIFA EASports method, the Neural Network model4 outperformed ordinal logistic regression.

We found that ORM was insufficient for replicating EA Sports' FIFA ratings. This perhaps could be due to the rather limited number of explanatory variables. Perhaps a greater array of variables containing predictive information could yield more robust model results when attempting to generate scores similar to those obtained from EA Sports'. The explanatory variables utilized within this research are some of the most readily available and commonly known variables pertaining to player performance. Another reason for the discrepancy between the ORM and EA Sports' ratings could be attributable to the linear transformation applied to the original fitted values from the ORM. With this in mind, perhaps another transformation would map the fitted values more closely to the values from the EA Sports ratings. 
Taking into consideration how substantially different the original fitted values from the ORM before the linear transformation are to the rankings from EA Sports', one could perhaps state that the overall modelling methodology is not effective in generating similar scores between the two models.

The second part of this research focused on demonstrating a methodology that would find the player(s) associated with a team winning (or not winning) games. We presented results for Juventus but other teams could be analyzed using the same method. Association rule mining proved to be a useful endeavour for gaining insight into this research question.

In regards to the use of Association Rule Mining, one could possibly further the analysis by utilizing weighted Association Rule Mining. This would be conducted by having weighted values for each variable associated with a player which would allow for more intuitive rules than the binary transaction data Association Rule Method implemented within this research.

Overall, the results within this research have demonstrated that analysing historical data can help us obtain information that is helpful for gaining a greater understanding of the underlying factors and phenomena related to player and team performance. 
There is a need to develop models that can handle game data that is sampled at a high frequency. This places emphasis on the model's ability to handle and process raw data and convert it quickly into a reliable form from which inference can be drawn during a game for on-demand/in-game analytics that seek to inform a team's choice. As shown by this thesis, the data does contain information that is useful for extracting inference. Therefore, if the nature of these hypothetical models could be developed so that in-game actions could be analyzed and processed rapidly, then the output from these models could be used to influence and alter game outcomes as the games are being played. This might bring an unprecedented level of demand for informative analytic models like those presented in this research.

It would seem intuitive to suggest that one of the ways to bring live analysis into a working form is to use live tracking data with a Convolutional Neural Network and other machine learning techniques that allow for a more automatic approach to conducting inference. By automatic, we simply mean that the statistician's expertise would be more heavily allocated towards the construction of the model a priori. This would lead to situations where one could derive characteristics about the game-play of opponents in a short timespan and therefore allow for the implementation of appropriate tactics to hinder or nullify an opponent's performance. An example of the legitimacy of these suggestions is depicted in sports like basketball and hockey where such 
analyses are occurring on relatively smaller scales. Given the similar dynamic nature of these sports with soccer, it would appear that the existence and development of these methodologies suggest the possibility of similar methods being developed for soccer.

\section{References}

[1] "OPTA INDEX", https://www.optasports.com/, accessed 19 April 2019.

[2] "Lega Serie A", http://www.legaseriea.it/en, accessed 13 November 2018.

[3] Sarmento, H., Marcelino, R., Anguera, M.T., CampaniÇo, J., Matos, N., LeitÃo, J.C. (2014). " Match analysis in football: a systematic review", Journal of Sports Sciences, Volume 32, No. 20, 1831-1843.

[4] Kaplan, T., Erkmen, N., Taskin, H. (2009). "The Evaluation of the Running Speed and Agility Performance in Professional and Amateur Soccer Players", Journal of Strength and Conditioning Research, Volume 23, Issue 3, 774-778.

[5] Di Salvo, V., Gregson, W., Atkinson, G., Tordoff, P., Drust, B.(2009). "Analysis of high intensity activity in Premier League", International Journal of Sports Medicine, Volume 30, Issue 3, 205-212 . 
[6] Carling, C. and Dupont, G. (2011). "Are declines in physical performance associated with a reduction in skill-related performance during professional soccer matchplay?", Journal of Sports Sciences, Volume 29, Issue 1, 63-71.

[7] Lyons, M.1., Al-Nakeeb, Y., Nevill, A. (2006). " Performance of soccer passing skills under moderate and high-intensity localized muscle fatigue", Journal of Strength and Conditioning Research, Volume 20, Issue 1, 197-202.

[8] Tenga, A., Holme, I., Ronglan, L.T., Bahr, R. (2010). "Effect of playing tactics on achieving score-box possessions in a random series of team possessions from Norwegian professional soccer matches", Journal of Sports Sciences, Volume 28, Issue 3, 245-255.

[9] . Reep, C. and Benjamin, B.(1968). "Skill and chance in association football", Journal of the Royal Statistical Society, Volume 141, Issue 4, 581-585.

[10] Pollard R. and Reep, C. (1997). "Measuring the effectiveness of playing strategies at soccer", Journal of the Royal Statistical Society, Volume 46, Issue 4, 541-550.

[11] Hughes, M. and Franks, I. (2005). "Analysis of passing sequences, shots and goals in soccer", Journal of Sports Sciences, Volume 23, Issue 9, 509-514 .

[12] Lago-Peñas, C. and Lago-Ballesteros, J. (2011). "Game location and team quality effects on performance profiles in professional soccer", Journal of Sports Science and Medicine, Volume 10, Issue 3, 465-471 
[13] Lago-Peñas, C., Lago-Ballesteros, J., Dellal, A., Gómez, M. (2010). "Game-Related Statistics that Discriminated Winning, Drawing and Losing Teams from the Spanish Soccer League", Journal of Sport Sciences, Volume 9, Issue 2, 288-293.

[14] Horn, R.,Williams, M., Ensum, J. (2002). "Attacking in central areas: A preliminary analysis of attacking play in the 2001/2002 FA Premiership season", Insight, Volume 3, Issue 5, 28-31.

[15] Taylor, S. and Williams, A.M. (2002)."World Cup 2002-Korea/Japon: A Quantitative analysis of Brazil's performances", Insight, Volume 4, 29-32.

[16] Pollard, R. (2002). "Charles Reep (1904-2002): pioneer of notational and performance analysis in football", Journal of Sports Sciences, Volume 20, Issue 10, 853-855.

[17] Lago-Peñas, C. and Dellal, A. (2010). "Ball Possession Strategies in Elite Soccer According to the Evolution of the Match-Score: the Influence of Situational Variables", Journal of Human Kinetics, Volume 25, 93-100.

[18] Tunaru, R.S. and Viney, H.P. (2010)."Valuations of Soccer Players from Statistical Performance Data", Journal of Quantitative Analysis in Sports, Volume 6, Issue 2, 10.

[19] Neter, J., Kutner, M.H., Nachtsheim, C.J., Wasserman, W. (1996). Applied Linear Statistical Models, 4th Edition, WCB McGraw-Hill, New York. 
[20] Winship, C. D. and Mane, R. (1984). "Regression Models With Ordinal Variables", American Sociological Review, Volume 49, 512-525.

[21] Liu, X., O'Connell,A. , Koirala, H. (2011). "Ordinal Regression Analysis: Predicting Mathematics Proficiency Using the Continuation Ratio Model", Journal of Modern Applied Statistical Methods, Volume 10, Issue 2, 513-527.

[22] Agresti, A. (2003). Categorical Data Analysis, 2nd Edition, New York: John Wiley \& Sons.

[23] Greene W. H. (2003). Econometric Analysis, 5th Edition, Pearson.

[24] "Ordinal regression - Wikipedia", https://en.wikipedia.org/wiki/Ordinal_regression, accessed 14 November 2018.

[25] "FIFA", https://resources.fifa.com/image/upload/fifa-disciplinary-code 500275.pdf?cloudid=koyeb3cvhxnwy9yz4aa6, accessed 20 April 2019

[26] "FIFA Index", https://www.fifaindex.com/players/fifa16_73/, accessed 26 April 2018

[27] Peterson, B.G., Carl, P., Boudt, K., Bennett, R., Ulrich, J., Zivot, E., Cornilly, D., Hung, E., Lestel, M., Balkissoon, K, Wuertz, D., (2018). " Econometric Tools for Performance and Risk Analysis," Volume 1.52 
[28] "Leard Statisitcs", https://statistics.laerd.com/spss-tutorials/ordinal-regressionusing-spss-statistics.php, accessed 20 April 2019

[29] Brant, R. (1990) "Assessing proportionality in the proportional odds model for ordinal logistic re-gression.Biometrics", Volume 46, 1171-1178

[30] Benjamini, Y., and Hochberg, Y. (1995). "Controlling the false discovery rate: a practical and powerful approach to multiple testing", Journal of the Royal Statistical Society, Series B, Volume 57, 289-300

[31] "ESPN", http://www.espn.com/espn/feature/story/_/id/23402874/world-cup-rankespn-fc\#!, accessed 20 April 2019

[32] "TheGuardian.Com", https://www.theguardian.com/football/nginteractive/2018/dec/18/the-100-best-male-footballers-in-the-world-2018-nos100-71, accessed 20 April 2019

[33] "Tuttosport Italia by Mercoledi", https://www.tuttosport.com/news/calcio/seriea/Juventus/2015/12/237001091/serie_a_Juventus_speedy_barzagli_lo_sprinter_Juve/, accessed 23 December 2015.

[34] "Juvefc by Vince Van Genechten", https://www.juvefc.com/exploring-lineupchange-juventus/, accessed 12 May 2016. 
[35] "fourfourtwo by Gregor MacGregor", https://www.fourfourtwo.com/features/11best-defenders-world, accessed 18 December 2015.

[36] "Football Italia", https://www.football-italia.net/121579/juventus-seek-cleansheet-record, accessed 19 May 2018. 